\title{
Het onbenutte arbeidspotentieel van apothekersassistenten voor de openbare apotheek
}

Citation for published version (APA):

Cörvers, F., Diephuis, B. J., \& Golsteyn, B. H. H. (2002). Het onbenutte arbeidspotentieel van apothekersassistenten voor de openbare apotheek. Researchcentrum voor Onderwijs en Arbeidsmarkt, Faculteit der Economische Wetenschappen. ROA Reports No. 2

https://doi.org/10.26481/umarep.2002002

Document status and date:

Published: 01/01/2002

DOI:

10.26481/umarep.2002002

Document Version:

Publisher's PDF, also known as Version of record

\section{Please check the document version of this publication:}

- A submitted manuscript is the version of the article upon submission and before peer-review. There can be important differences between the submitted version and the official published version of record.

People interested in the research are advised to contact the author for the final version of the publication, or visit the DOI to the publisher's website.

- The final author version and the galley proof are versions of the publication after peer review.

- The final published version features the final layout of the paper including the volume, issue and page numbers.

Link to publication

\footnotetext{
General rights rights.

- You may freely distribute the URL identifying the publication in the public portal. please follow below link for the End User Agreement:

www.umlib.nl/taverne-license

Take down policy

If you believe that this document breaches copyright please contact us at:

repository@maastrichtuniversity.nl

providing details and we will investigate your claim.
}

Copyright and moral rights for the publications made accessible in the public portal are retained by the authors and/or other copyright owners and it is a condition of accessing publications that users recognise and abide by the legal requirements associated with these

- Users may download and print one copy of any publication from the public portal for the purpose of private study or research.

- You may not further distribute the material or use it for any profit-making activity or commercial gain

If the publication is distributed under the terms of Article $25 \mathrm{fa}$ of the Dutch Copyright Act, indicated by the "Taverne" license above, 


\section{Het onbenutte arbeidspotentieel van apothekersassistenten voor de openbare apotheek}

ROA-R-2002/2

Frank Cörvers

Bart J. Diephuis

Bart Golsteyn

Researchcentrum voor Onderwijs en Arbeidsmarkt

Faculteit der Economische Wetenschappen en Bedrijfskunde Universiteit Maastricht

Maastricht, januari 2002 
ISBN 90-5321-328-7

Sec02.018.doc 


\section{Inhoud}

Bladzijde

Voorwoord

1 Inleiding 1

2 Omvang en samenstelling van het onbenutte arbeidspotentieel 5

3 De niet-participerende apothekersassistenten 11

4 De werkloze apothekersassistenten $\quad 29$

5 De werkenden buiten de openbare apotheek 39

6 Conclusie: de weg terug naar de openbare apotheek 47

Bijlage A. Steekproeftrekking en weging 55

Bijlage B. Vragenlijst

Bijlage C. Statistische Bijlage $\quad 63$ 



\section{Voorwoord}

Dit onderzoek is een onderdeel van de arbeidsmarktmonitor voor de openbare apotheek, waarvan een beschrijving wordt gegeven in het Vooronderzoek arbeidsmarktmonitor apothekersbranche ${ }^{1}$. Voor het uitvoeren van de arbeidsmarktmonitor heeft de Stichting Bedrijfsfonds Apotheken (SBA) opdracht verleend aan het Researchcentrum voor Onderwijs en Arbeidsmarkt. De arbeidsmarktmonitor bestaat uit een monitoring van werkenden en werkgevers van de openbare apotheek, schoolverlaters van de opleiding voor apothekersassistent, en gediplomeerde apothekersassistenten die voorheen in de openbare apotheek hebben gewerkt. Bovendien zal er in kader van de deze monitoring een toekomstverkenning van de arbeidsmarkt voor apothekersassistenten plaatsvinden.

Het onderzoek in dit rapport gaat met name over de achtergrondkenmerken van gediplomeerde apothekersassistenten die ooit in de openbare apotheek hebben gewerkt, en hun overwegingen om eventueel terug te keren naar de openbare apotheek. De belangrijkste groep van deze gediplomeerde apothekersassistenten bestaat uit degenen die niet participeren op de arbeidsmarkt, maar mogelijk bereid zijn tot herintrede. Daarnaast komen ook de werklozen en de werkenden buiten de openbare apotheek aan de orde. Tezamen vormen deze groepen het onbenutte arbeidspotentieel voor de openbare apotheek.

We zijn dank verschuldigd aan dhr. M. van Aken van het Pensioenfonds Medewerkers Apotheken (PMA) voor het ter beschikking stellen van het steekproefbestand met NAW-gegevens, dhr. L. Schreurs en mw. J. Stijlen van bureau Intomart voor de coördinatie van het veldwerk, en dhr. J. Sax van der Weijden van de SBA voor zijn commentaar op de samenstelling van de vragenlijst en de beschrijving van de onderzoeksresultaten in dit rapport.

1. F. Cörvers en A. de Grip, Vooronderzoek arbeidsmarktmonitor apothekersbranche, Researchcentrum voor Onderwijs en Arbeidsmarkt, Maastricht, 2001. 


\section{Inleiding}

Uit recent onderzoek onder werkgevers van onder meer de zorgsector ${ }^{2}$, blijkt dat werklozen en herintreders goed op de arbeidsmarkt kunnen concurreren met schoolverlaters als zij beschikken over een passende opleiding en relevante werkervaring. Bovendien lijken juist in de zorgsector werklozen en herintreders nog een redelijk gelijkwaardige positie in te nemen ten opzichte van degenen die er al een baan hebben. Ook voor werkgevers in de openbare apotheek - de apothekers kan het onbenutte arbeidspotentieel van werklozen en herintreders die een opleiding voor apothekersassistent hebben afgerond van belang zijn. Daarnaast kan het voor de apothekers van belang zijn om de uitgetreden apothekersassistenten die een baan buiten de openbare apotheek hebben gevonden, te interesseren voor een terugkeer naar hun voormalige werkgever. Deze werkenden, werklozen en herintreders met het diploma voor apothekersassistent kunnen, afhankelijk van bijvoorbeeld hun werkervaring, een interessante doelgroep vormen die aangeboord zou kunnen worden om de knelpunten in de personeelsvoorziening in de openbare apotheek te verlichten.

Willen apothekers erin slagen om de terugkeer van apothekersassistenten naar de openbare apotheek te stimuleren, dan moet men weten wat er speelt. Wat is de huishoud- en inkomenssituatie van de uitgetreden apothekersassistenten? Hebben hun wensen betrekking op het salaris, de werktijden, de werkdruk, het imago van de openbare apotheek of op andere voorwaarden en belemmeringen? Hoe beoordelen zij hun werk als apothekersassistent, en welke rol speelt de uitstraling van de openbare apotheek daarbij? Op welke wijze kan een werkgever van de openbare apotheek de herintreders, de werklozen en de werkenden die een diploma voor apothekersassistent hebben behaald, aan zich binden?

Dit rapport beoogt duidelijk te maken (1) wat de achtergrondkenmerken zijn van de uitgetreden apothekersassistenten, (2) wat hun redenen zijn geweest om te stoppen met het werk in de openbare apotheek of om een andere baan te zoeken, (3) in welke mate zij bereid zijn tot het aanvaarden van een baan in de openbare apotheek of daarnaar op zoek zijn, (4) wat volgens hen de voornaamste belemmeringen zijn voor een eventuele terugkeer, en (5) wat er toe zou kunnen leiden dat een deel van hen daadwerkelijk terugkeert als apothekersassistent in de openbare apotheek.

Een en ander moet vervolgens resulteren in een beter zicht op de potentiële instroom van voormalige apothekersassistenten in de openbare apotheek. Het zicht op een reële omvang van de groep van voormalige apothekersassistenten en de afstand die zij tot de arbeidsmarkt hebben, kan een belangrijke leidraad zijn voor de Stichting Bedrijfsfonds Apotheken (SBA) en voor de werkgevers in de branche om in het rekruteringsbeleid beter rekening te houden met de wensen van het onbenutte potentieel.

2. Zie W. Smits, Personee/sselectie in de Zorg, de Metaalindustrie en de IT, ROA-W-2001/2, Maastricht, 2001. 
In dit rapport wordt gebruik gemaakt van gegevens van het Centraal Bureau voor de Statistiek (CBS) en het Pensioenfonds Medewerkers Apotheken (PMA). De belangrijkste gegevensbron was echter de enquête die het ROA heeft laten uitvoeren door bureau Intomart onder apothekersassistenten die werkzaam zijn geweest in de openbare apotheek. De onderzoeksopzet en de vragenlijst staan volledig onder verantwoordelijkheid van het ROA. In bijlage A en B wordt achtereenvolgens kort weergegeven hoe de enquête is opgezet en welke vragen zijn gesteld. Voorts wordt in bijlage $A$ aangegeven welke weging heeft plaatsgevonden ter correctie van de non-respons. In bijlage $\mathrm{C}$ zijn alle (gewogen) resultaten van de enquête opgenomen.

Van belang is dat in hoofdstuk 2 de gegevens van het CBS uit de Enquête Beroepsbevolking (EBB) gecombineerd zijn met de gegevens van het PMA en de enquêtegegevens onder voormalige apothekersassistenten van de openbare apotheek. Hierdoor kon de totale omvang van de verschillende groepen van werkenden en niet-werkenden in Nederland en de zes regio's worden vastgesteld. In de hoofdstukken 3,4 en 5 is daarentegen uitsluitend gebruik gemaakt van de enquêtegegevens van de voormalige apothekersassistenten van de openbare apotheek (gecorrigeerd voor non-respons). In deze hoofdstukken komen de achtergrondkenmerken en motieven aan de orde van achtereenvolgens de nietparticiperenden, de werklozen en de werkenden buiten de openbare apotheek. De daarbij gebruikte gegevens hebben betrekking op een selecte steekproef, namelijk van niet-participerenden, werklozen en werkenden die ooit als apothekersassistent in de openbare apotheek hebben gewerkt en daar pensioenrechten aan hebben overgehouden.

Het bovenstaande betekent dat de selecte groep van uitgetreden apothekersassistenten die een vragenlijst hebben ontvangen per definitie werkervaring heeft in de openbare apotheek. Het gaat hierbij om ongeveer 3.750 gediplomeerde apothekersassistenten, van wie de helft gerespondeerd heeft. Deze groep heeft ooit in de openbare apotheek gewerkt, waardoor de enquêteresultaten van deze groep niet zonder meer generaliseerbaar zijn voor alle gediplomeerde apothekersassistenten die niet of buiten de openbare apotheek werkzaam zijn. Het aantal gediplomeerde apothekersassistenten buiten de openbare apotheek - werkenden en nietwerkenden - bedraagt ongeveer 16.500 personen (zie hoofdstuk 2). Dit betekent dat bijna een kwart van de gediplomeerde apothekersassistenten is geënquêteerd via het pensioenbestand van het PMA. De selectiviteit van de steekproef is het duidelijkst voor een achtergrondkenmerk als het aantal jaren ervaring in het beroep van apothekersassistent of met het werk in de openbare apotheek, maar geldt waarschijnlijk ook voor bijvoorbeeld de antwoorden op de vragen naar de noodzaak tot bijscholing en de beoordeling achteraf van de opleiding tot apothekersassistent ${ }^{3}$.

3. Enerzijds dient men bij de interpretatie van de resultaten met de betrekking tot deze variabelen dus rekening te houden met de selectiviteit. Anderzijds is het op grond van het Schoolverlatersinformatiesysteem (SIS) van het ROA bekend dat al jarenlang meer dan 90 procent van de schoolverlaters met het diploma voor apothekersassistent in eerste instantie in de eigen vakrichting (als apothekersassistent) gaat werken. 
In hoofdstuk 2 wordt een beeld gegeven van de omvang van de vier categorieën binnen het onbenutte arbeidspotentieel voor de openbare apotheek, namelijk de nietparticiperenden, de werklozen, de werkenden die als apothekersassistenten buiten de openbare apotheek werken, en de overige werkenden buiten de openbare apotheek. Verder wordt in het hoofdstuk ingegaan op de regionale omvang van het onbenutte arbeidspotentieel. Bovendien wordt gekeken naar de leeftijdsopbouw van het onbenutte arbeidspotentieel.

De niet-participerende apothekersassistenten waarop in hoofdstuk 3 wordt ingegaan, is qua omvang het grootst, en zal ook het meest uitgebreid in dit rapport worden behandeld. Deze groep wordt gevormd door de gediplomeerde apothekersassistenten die noch werkloos noch werkzaam zijn. Zij verrichten huishoudelijk werk en zorgtaken, studeren of zijn arbeidsongeschikt. Zij zijn doorgaans niet op zoek naar betaald werk. In het hoofdstuk zal nader worden ingegaan op de persoonlijke en huishoudsituatie van de niet-participerenden, waaronder de belangrijkste bezigheid, de gezinssamenstelling en het inkomen. Bovendien zal worden ingegaan op onder andere het arbeidsverleden en de reden van uittrede, de bereidheid tot herintrede, de belemmeringen daarbij, en het imago van de openbare apotheek.

In hoofdstuk 4 wordt verder ingegaan op de werklozen. De afstand tot de arbeidsmarkt van de werklozen is waarschijnlijker kleiner dan van de niet-participerenden, hetgeen duidelijk zou moeten worden uit de bereidheid om weer aan de slag te gaan en de belemmeringen die daarbij ervaren worden. Naast verschillende onderwerpen die ook voor de niet-participerenden worden besproken, zal tevens worden ingegaan op de werkloosheidsduur, het zoekgedrag en of men is ingeschreven bij het arbeidsbureau.

In hoofdstuk 5 komen vervolgens de gediplomeerde apothekersassistenten aan bod die een baan buiten de openbare apotheek hebben. Zij kunnen nog steeds werkzaam zijn als apothekersassistent, maar ook een ander beroep uitoefenen. Deze werkenden zouden vanwege hun opleiding en ervaring waarschijnlijk in staat zijn om terug te keren naar de openbare apotheek, als ze dat zouden willen. Naast een aantal eerder genoemde onderwerpen, zal bij de werkenden buiten de openbare apotheek ook worden ingegaan op de redenen waarom ze de openbare apotheek hebben verlaten en onder welke financiële randvoorwaarden ze een eventuele terugkeer overwegen.

Hoofdstuk 6 sluit dit rapport af met de conclusies over de mogelijkheden van een terugkeer naar de openbare apotheek van apothekersassistenten uit de vier verschillende groepen van het onbenutte arbeidspotentieel. 



\section{Omvang en samenstelling van het onbenutte arbeidspotentieel}

Van de potentiële beroepsbevolking in Nederland (iedereen van 15 tot 65 jaar) hebben ongeveer 29.000 personen ooit het diploma van apothekersassistent behaald. Dit aantal geeft het totale potentiële aanbod weer dat apothekers, als werkgevers van een openbare apotheek, zouden kunnen inzetten voor het vervullen van de vraag naar gediplomeerde apothekersassistenten. Uit figuur 2.1 blijkt dat ongeveer tweederde van deze gediplomeerde apothekersassistenten reeds betaald werk verricht, waaronder een groot deel als apothekersassistent (AA) in een openbare apotheek (OA). Eenderde van de gediplomeerde apothekersassistenten is werkloos of participeert niet op de arbeidsmarkt. Deze laatste twee groepen vormen samen met de gediplomeerde apothekersassistenten die buiten de openbare apotheek werken, het onbenutte arbeidspotentieel voor de openbare apotheek.

Figuur 2.1

Gediplomeerde apothekersassistenten en het onbenutte arbeidspotentieel voor de openbare apotheek, 1999-2000

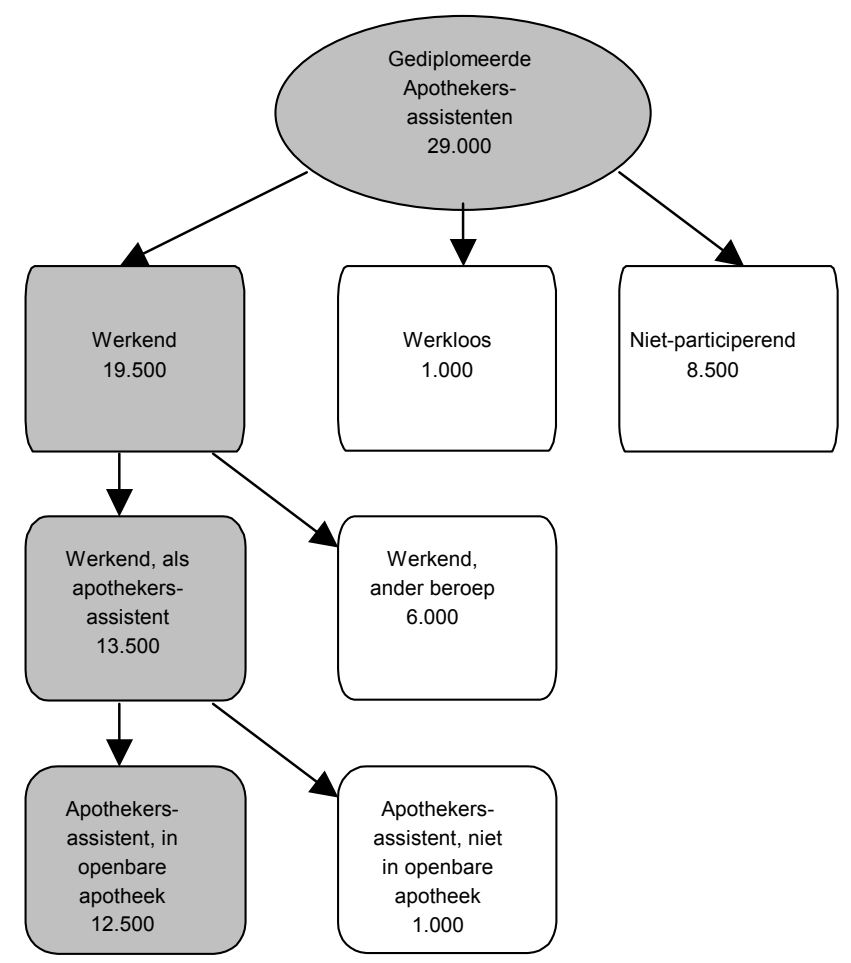

Noot: Het onbenutte arbeidspotentieel van apothekersassistenten voor de openbare apotheek is weergegeven in de witte vakken.

Bron: ROA/PMA/CBS 
Het onbenutte arbeidspotentieel voor de openbare apotheek bedraagt ongeveer 16.500 mensen, oftewel 56 procent van het totale aantal mensen met een diploma voor apothekersassistent. Dit zijn bijna allemaal vrouwen (98 procent). De meeste gediplomeerde mannelijke apothekerassistenten werken bovendien buiten de openbare apotheek.

Uit de figuur blijkt dat van de vier groepen die het onbenutte arbeidspotentieel voor de openbare apotheek vormen, het aantal niet-participerenden met 8.500 het grootst is. Dit is 52 procent van het onbenutte arbeidspotentieel. Daarnaast is er een relatief kleine groep van ongeveer 1.000 werklozen, i.e. 6 procent van het onbenutte arbeidspotentieel. De werkenden van het onbenutte arbeidspotentieel kunnen worden onderverdeeld in degenen die als apothekersassistent buiten de openbare apotheek werkzaam zijn en degenen die helemaal niet meer als apothekersassistent werkzaam zijn. Deze laatste groep is relatief groot en bestaat uit ca. 6.500 mensen (36 procent). Ongeveer 1.000 mensen (6 procent) hebben weliswaar het beroep van apothekersassistent, maar werken niet in de openbare apotheek.

Figuur 2.2

Leeftijdsopbouw van de vier categorieën van het onbenutte arbeidspotentieel, 2000

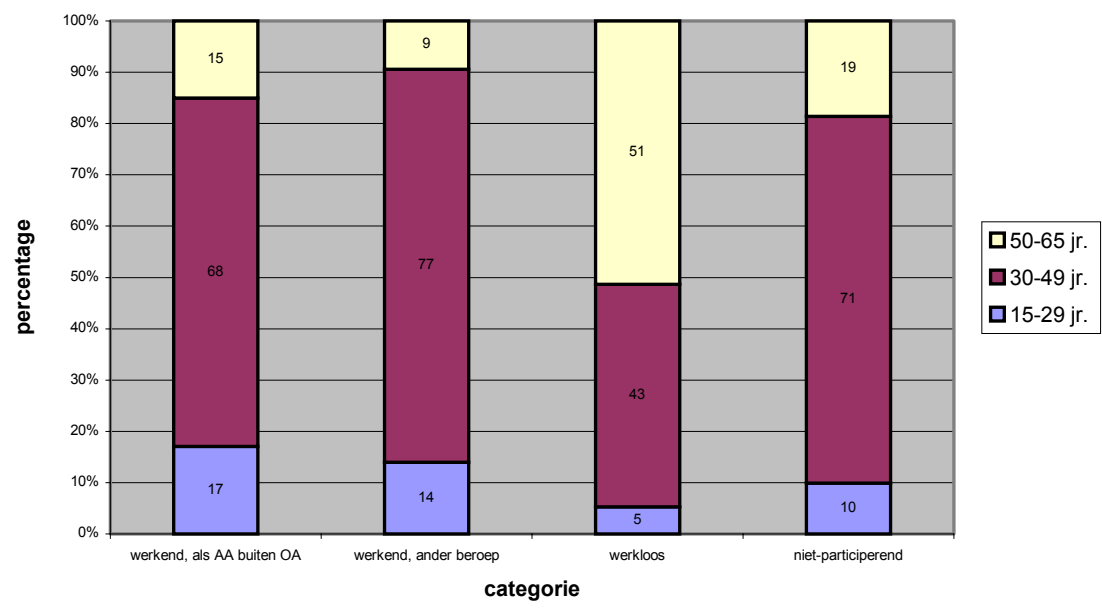

Bron: ROA/PMA

In de figuren 2.2 en 2.3 wordt het onbenutte arbeidspotentieel verder uitgesplitst naar leeftijdsklasse respectievelijk regio. Uit figuur 2.2 blijkt dat ruim 70 procent van de niet-participerenden tussen 30 en 49 jaar oud is. Bij de niet-participerenden in deze leeftijdsklasse zou een eventuele terugkeer naar de openbare apotheek vooral een rol kunnen gaan spelen als de zorgtaken binnen het gezin afnemen doordat bijvoorbeeld hun kinderen ouder worden. Onder de werkenden is het percentage jongeren groter en het percentage ouderen kleiner dan onder de niet-participerenden. De werkenden die nog als apothekersassistent buiten de openbare apotheek actief zijn, lopen weinig kans op verlies van kennis en vaardigheden. Dit is uiteraard anders bij de werkenden in een ander beroep, onder wie een groot percentage van middelbare leeftijd is. Als zij ouder worden en gedurende een langere periode het 
beroep van apothekersassistent niet meer uitoefenen, zullen de meeste van hen zeker de eerder opgedane kennis en ervaring geleidelijk aan verliezen. De leeftijdsopbouw van de werklozen wijkt duidelijk af van de andere drie categorieën: meer dan de helft van de werklozen is ouder dan 50 jaar. Ook voor hen zal de duur van de inactiviteit in belangrijke mate de directe inzetbaarheid in de openbare apotheek bepalen.

In tabel 2.1 is de gehanteerde regio-indeling van dit rapport weergegeven. Er worden zes grote regio's, gebaseerd op de voormalige RBA-gebieden, onderscheiden ${ }^{4}$.

Tabel 2.1

Regio-indeling naar RBA-gebieden

\begin{tabular}{|c|c|c|}
\hline Regio & RBA-gebieden & RBA-nummers \\
\hline Noord-Nederland & Groningen, Friesland, Drenthe & $1,2,3$ \\
\hline Oost-Nederland & Overijssel, IJssel-Veluwe, Gelderland & $4,5,6$ \\
\hline Noordwest-Nederland & $\begin{array}{l}\text { Flevoland, Noordelijk Noord-Holland, } \\
\text { Zuidelijk Noord-Holland }\end{array}$ & $7,9,10$ \\
\hline Middenwest-Nederland & $\begin{array}{l}\text { Midden-Nederland, Rijnstreek, } \\
\text { Haaglanden }\end{array}$ & $8,11,12$ \\
\hline Zuidwest-Nederland & Rijnmond, Zeeland, West-Brabant & $13,14,15$ \\
\hline Zuidoost-Nederland & $\begin{array}{l}\text { Noordoost-Brabant, Limburg, } \\
\text { Zuidoost-Brabant }\end{array}$ & $16,17,18$ \\
\hline
\end{tabular}

In figuur 2.3 is het onbenutte arbeidspotentieel als percentage van het aantal gediplomeerde apothekersassistenten voor Nederland en de zes verschillende regio's weergegeven. Dit percentage bedraagt 56 procent voor heel Nederland. In het algemeen blijken er geen grote verschillen tussen de regio's te bestaan. Het percentage is het grootst in Noordwest- (59 procent) en Middenwest-Nederland (58 procent), en het kleinst in Noord-Nederland (53 procent). In Noordwest-Nederland komt dat door het grote percentage werklozen en werkenden in een ander beroep, terwijl in Middenwest-Nederland het grote percentage niet-participerenden daarvan de oorzaak is. In het Noordwesten is het percentage niet-participerenden juist laag, hetgeen kan wijzen op een grotere behoefte om betaald werk te verrichten in deze regio. Daarentegen is het aandeel niet-participerenden niet alleen hoog in Middenwest-Nederland, maar ook in Zuidoost-Nederland. Tot slot blijkt het relatief kleine onbenutte arbeidspotentieel in Noord-Nederland samen te hangen met het lage aandeel mensen dat hier in een ander beroep buiten de openbare apotheek werkt. De oorzaak hiervan zou kunnen liggen in de geringere uitwijkmogelijkheden van gediplomeerde apothekersassistenten in deze regio om in ander beroep te werken.

In figuur 2.4 wordt een beeld gegeven van de leeftijdsopbouw van het onbenutte arbeidspotentieel per regio. Ook hier doen zich geen grote verschillen tussen regio's voor. Het onbenutte arbeidspotentieel in Nederland bestaat voor 72 procent uit 
personen van middelbare leeftijd, voor 12 procent uit jongeren en voor 16 procent uit ouderen. Met name in Noord-Nederland is het onbenutte arbeidspotentieel relatief jong, met een hoog percentage jongeren en een laag percentage ouderen. In Noordwest- en Middenwest-Nederland wonen de meeste ouderen, en in OostNederland is maar liefst 77 procent van middelbare leeftijd.

\section{Figuur 2.3}

Het onbenutte arbeidspotentieel als percentage van het aantal gediplomeerde apothekersassistenten naar regio, 1999-2000

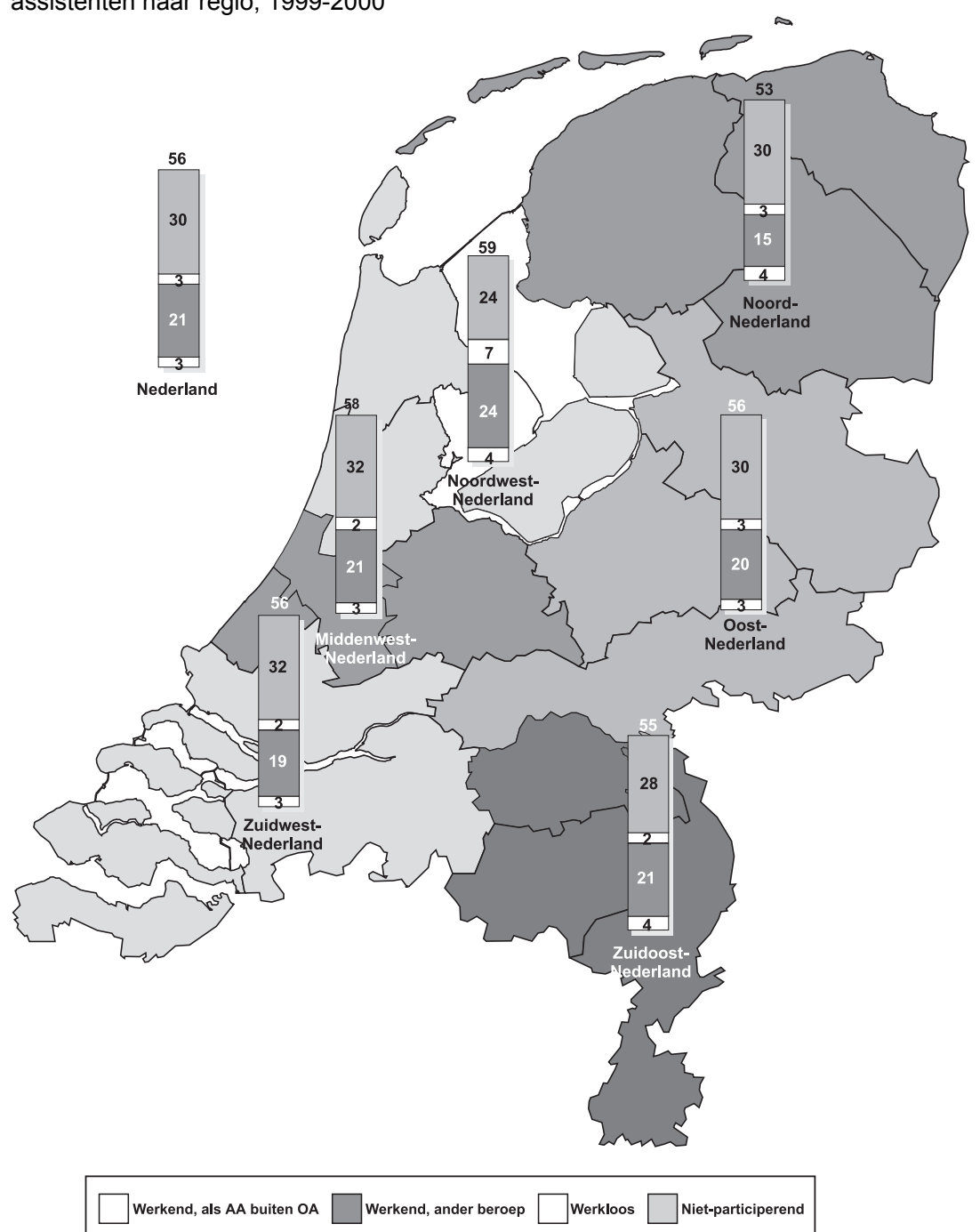

Bron: ROA/PMA/CBS

4. In bijlage $\mathrm{C}$ van dit rapport worden weliswaar kleinere regio's (provincies en RBA-gebieden) onderscheiden, maar de gepresenteerde gegevens voor deze regio's geven vanwege de onbetrouwbaarheidsmarges slechts een grove indicatie. 
Figuur 2.4

Leeftijdsopbouw van het onbenutte arbeidspotentieel naar regio, in procenten van het totaal, 2000

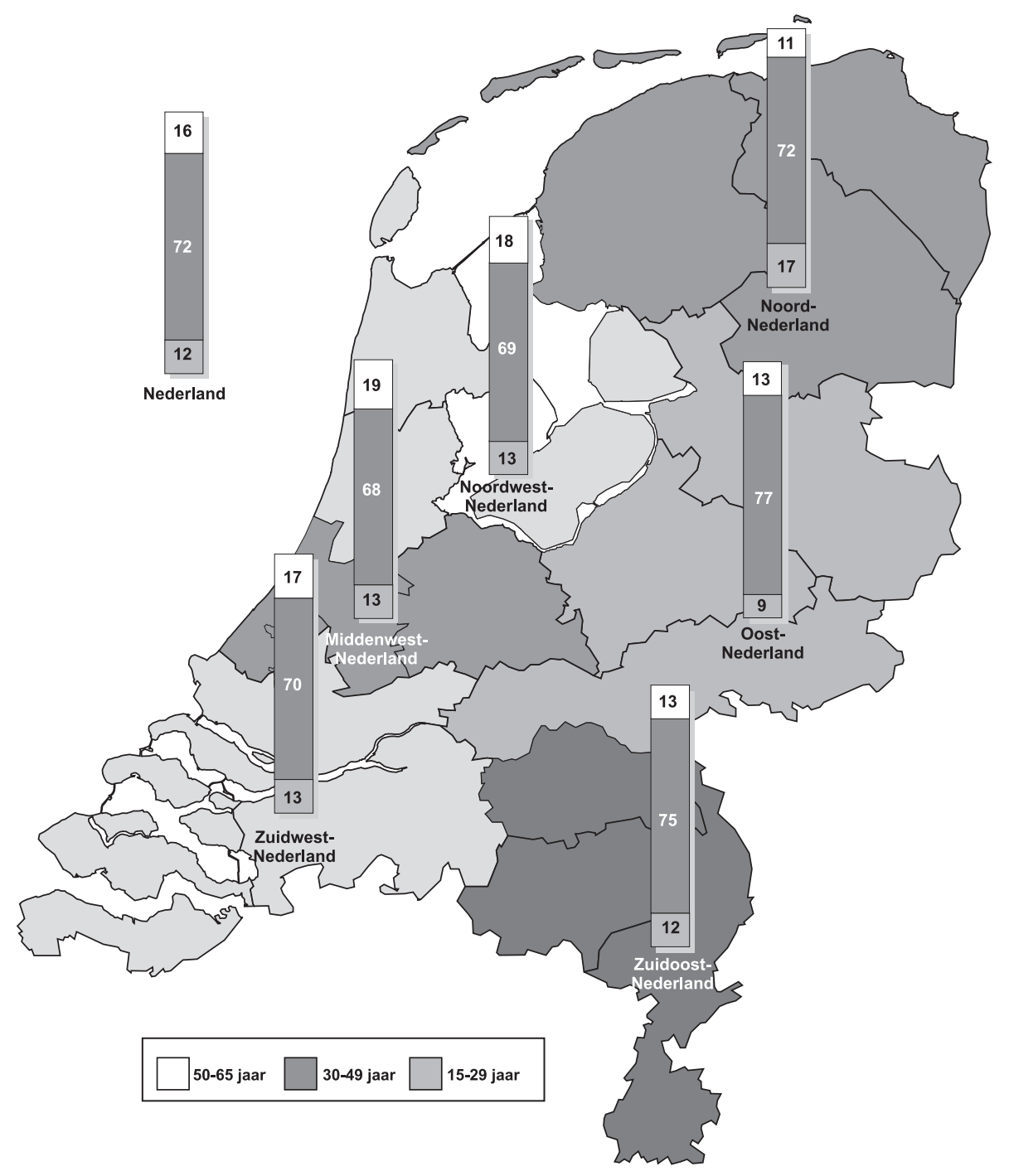

Bron: ROA/PMA 



\section{De niet-participerende apothekersassistenten}

In dit hoofdstuk komt de eerste potentiële aanbodgroep van gediplomeerde apothekersassistenten aan de orde, de groep van niet-participerenden. Deze nietparticiperenden zijn ooit werkzaam geweest als apothekersassistent in een openbare apotheek, maar zijn nu noch werkzaam, noch werkloos. Hun bezigheden kunnen bijvoorbeeld bestaan uit huishoudelijke werkzaamheden, de zorg voor de kinderen of studie. De niet-participerende apothekersassistenten behoren niet tot de beroepsbevolking, omdat ze zich doorgaans niet aanbieden op de arbeidsmarkt. Dit in tegenstelling tot de werkloze apothekersassistenten, die zich doordat ze betaald werk zoeken, wel aanbieden op de arbeidsmarkt en derhalve tot de beroepsbevolking kunnen worden gerekend.

Ondanks dat niet-participerenden niet actief zoeken naar betaald werk, is het denkbaar dat een deel van hen op korte of langere termijn beschikbaar is voor de arbeidsmarkt. Om beter zicht te krijgen op de beschikbaarheid van het arbeidspotentieel van niet-participerende apothekersassistenten wordt in dit hoofdstuk eerst nader ingegaan op hun achtergrond en huidige situatie. In hoofdstuk 2 is al ingegaan op de achtergrondkenmerken naar leeftijd en geslacht. Ruim 99 procent van de nietparticiperende apothekersassistenten is vrouw. Bijna de helft valt in de leeftijdsklasse van 35 tot 45 jaar, en 17 procent valt in de leeftijdsklasse van 45 tot 50 jaar. Het gaat in totaal om ongeveer 8.500 niet-participerenden.

In dit hoofdstuk wordt nader ingegaan op de persoonlijke en huishoudsituatie, waaronder de belangrijkste bezigheid en de gezinssamenstelling. Bovendien wordt ingegaan op het huidige persoonlijke en huishoudinkomen, het arbeidsverleden en de reden van uittrede, de bereidheid tot herintrede als apothekersassistent in een openbare apotheek, en het imago van de openbare apotheek.

\section{Persoonlijke en huishoudsituatie}

De persoonlijke situatie van de niet-participerende apothekersassistenten is bekeken aan de hand van de voornaamste bezigheid. Figuur 3.1 geeft aan wat de voornaamste bezigheid is van de niet-participerenden. Ongeveer tweederde van de nietparticiperenden geeft huishoudelijk werk en zorgtaken aan als voornaamste tijdsbesteding. Een deel van de niet-participerenden, 12 procent, houdt zich bezig met studie en 6 procent zit noodgedwongen thuis vanwege arbeidsongeschiktheid. Verder geeft 17 procent aan iets te doen dat niet gevat kan worden onder de andere categorieën. Er kan hier gedacht worden aan bijvoorbeeld vrijwilligerswerk. Bovendien zijn er ook mensen die wel aangeven enkele uren per week betaald werk te verrichten, maar die dit vanwege het geringe aantal uren niet als voornaamste bezigheid zien.

Het hoge percentage niet-participerenden dat huishoudelijk werk en zorgtaken als voornaamste bezigheid ziet, houdt waarschijnlijk verband met de huishoudsituatie 
van deze niet-participerenden. Vanwege de aanwezigheid van kinderen en een werkende partner, hebben zij zich toegelegd op taken binnen het huishouden.

Figuur 3.1

Persoonlijke situatie van niet-participerenden, 2001

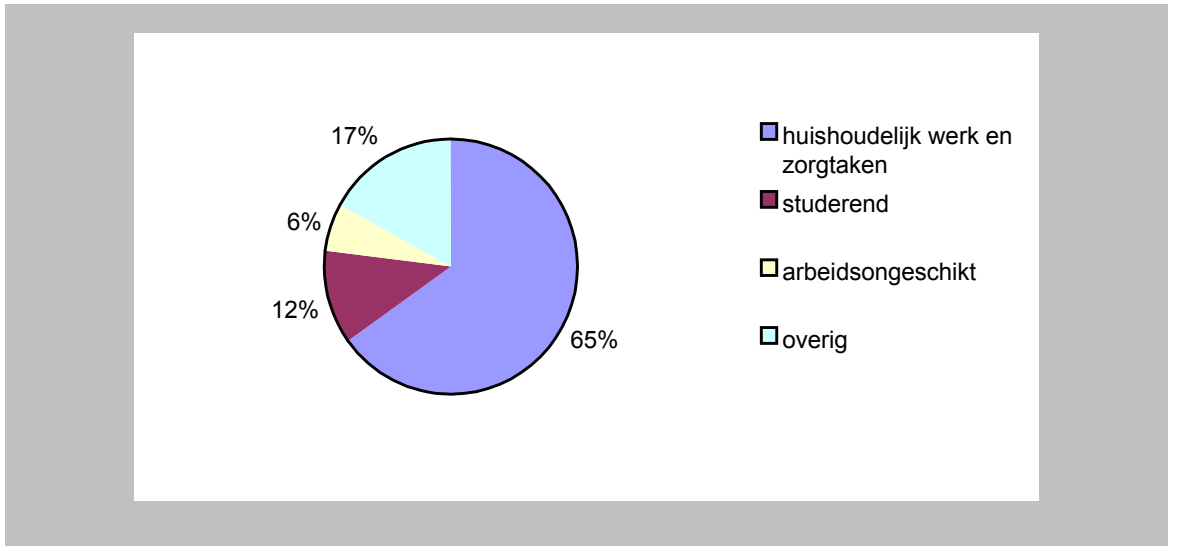

Bron: ROA

Tabel 3.1 laat zien wat er in het algemeen over de huishoudsituatie van de nietparticiperenden gezegd kan worden. Maar liefst 91 procent van de niet-participerende apothekersassistenten heeft een partner. Verder geldt dat 77 procent één of meer thuiswonende kinderen heeft.

Tabel 3.1

Huishoudsituatie van niet-participerenden, 2001

\begin{tabular}{lrr}
\hline Kenmerk & $\%$ & $\%$ \\
\hline Partner & & \\
Geen thuiswonende kinderen & - & - \\
Eén thuiswonend kind & - & 15 \\
Minimaal twee thuiswonende kinderen & - & 66 \\
Totaal & - & \\
Geen partner & 9 & - \\
Geen thuiswonende kinderen & - & 61 \\
Eén thuiswonend kind & - & 21 \\
Minimaal twee thuiswonende kinderen & - & 100 \\
Totaal & 100 & - \\
Totaal & - & 23 \\
Geen thuiswonende kinderen & - & 15 \\
Eén thuiswonend kind & - & 62 \\
Minimaal twee thuiswonende kinderen & - & 100 \\
Totaal & & \\
\hline Bron: ROA & &
\end{tabular}

Bron: ROA

Het hebben van een partner en kinderen is waarschijnlijk het meest van toepassing op de niet-participerenden die als voornaamste bezigheid huishoudelijk werk en zorgtaken hebben. De huishoudsituatie van deze niet-participerenden is nog eens apart weergegeven in tabel 3.2. Het blijkt dat 97 procent van deze groep een partner 
heeft en dat 94 procent minimaal één thuiswonend kind heeft. Zowel een partner als kinderen komen dus relatief vaak voor bij de niet-participerenden die huishoudelijk werk en zorgtaken verrichten. Bij acht van de tien van hen komt de gezinsgrootte zelfs uit op minimaal vier personen, namelijk de apothekersassistent en de partner, en minimaal twee kinderen. Voor de kleine groep niet-participerenden zonder partner die huishoudelijk werk of zorgtaken verrichten, geldt dat ze allemaal minimaal één thuiswonend kind hebben. In driekwart van deze eenoudergezinnen zijn er zelfs twee of meer thuiswonende kinderen.

Tabel 3.2

Huishoudsituatie van niet-participerenden met huishoudelijk werk en zorgtaken, 2001

\begin{tabular}{lrr}
\hline Kenmerk & $\%$ & $\%$ \\
\hline Partner & 97 & - \\
Geen thuiswonende kinderen & - & 6 \\
Eén thuiswonend kind & - & 14 \\
Minimaal twee thuiswonende kinderen & - & 80 \\
Totaal & - & 100 \\
& 3 & - \\
Geen partner & - & 0 \\
Geen thuiswonende kinderen & - & 25 \\
Eén thuiswonend kind & - & 75 \\
Minimaal twee thuiswonende kinderen & - & 100 \\
Totaal & 100 & - \\
Totaal & - & 6 \\
Geen thuiswonende kinderen & - & 14 \\
Eén thuiswonend kind & - & 80 \\
Minimaal twee thuiswonende kinderen & - & 100 \\
Totaal & & \\
\hline Bron: RoA & &
\end{tabular}

Bron: ROA

Van belang voor de beschikbaarheid van de niet-participerende apothekersassistenten zou de leeftijd van hun jongste thuiswonende kind kunnen zijn. Naarmate een kind jonger is, is het immers afhankelijker van de ouder (moeder) en vereist het meer verzorging. In tabel 3.3 is weergegeven wat de leeftijd is van het jongste thuiswonende kind, uitgesplitst naar alle niet-participerenden en naar de niet-participerenden die huishoudelijk werk of zorgtaken verrichten.

Bij 55 procent van de niet-participerende apothekersassistenten is het jongste thuiswonende kind jonger dan 5 jaar, en bij meer dan eenderde zelfs jonger dan 3 jaar. Voor de niet-participerenden die huishoudelijk werk of zorgtaken verrichten geldt dit in nog sterkere mate. De niet-participerende apothekersassistenten die huishoudelijk werk of zorgtaken hebben voor 59 procent een kind jonger dan vijf jaar, versus 55 procent voor de totale groep van niet-participerenden.

De aanwezigheid van een partner maar vooral het hebben van kinderen onder nietparticiperende apothekersassistenten, lijkt een belangrijke verklaring te zijn voor de keuze voor het verrichten van huishoudelijk werkzaamheden en het op zich nemen van zorgtaken in plaats van het verrichten van betaald werk. Andere redenen om niet te participeren zijn gelegen in de keuze om te studeren of in arbeidsongeschiktheid. 
Tabel 3.3

Leeftijd van jongste thuiswonende kind van niet-participerenden met minimaal één kind, 2001

\begin{tabular}{lrr}
\hline Leeftijd in jaren & $\begin{array}{r}\text { huishoudelijk werk } \\
\text { en zorgtaken } \\
\%\end{array}$ & $\begin{array}{r}\text { totaal } \\
\%\end{array}$ \\
\hline $0-2$ & 36 & 33 \\
$3-4$ & 23 & 22 \\
$5-9$ & 28 & 28 \\
$10-14$ & 7 & 6 \\
$15-19$ & 4 & 3 \\
Total & 1 & 100 \\
\hline
\end{tabular}

Bron: ROA

\section{Huidig inkomen}

Een belangrijke stimulans om betaald werk te verrichten of te zoeken is het verwerven van voldoende inkomen. Om een beeld te krijgen van het mogelijke belang van het te verdienen inkomen voor het aanvaarden van een betaalde baan door nietparticiperenden, kan worden gekeken naar hun huidige inkomenssituatie. Als een partner in het levensonderhoud voorziet, is de noodzaak tot het verrichten van betaald werk geringer. Uit tabel 3.2 is al gebleken dat veruit de meerderheid van de niet-participerende (vrouwelijke) apothekersassistenten een (mannelijke) partner heeft.

In tabel 3.4 zijn het persoonlijke netto maandinkomen en het totale netto maandinkomen van het huishouden (inclusief dat van de partner) weergegeven. Uit de tabel blijkt dat het persoonlijk netto maandinkomen van de niet-participerende apothekersassistenten grotendeels minimaal is. Van de niet-participerenden heeft bijna tweederde geen persoonlijk inkomen, terwijl 16 procent een persoonlijk inkomen heeft tussen 750 en 950 gulden netto per maand (inkomensklasse 1-999 gulden in de tabel). Dit inkomen kan verkregen zijn op basis van bijvoorbeeld een uitkering of uit kleine nevenwerkzaamheden.

Uit tabel 3.4 blijkt verder dat het huishoudinkomen veel hoger ligt dan het persoonlijke inkomen van de niet-participerende apothekersassistenten. Het huishoudinkomen ligt in bijna 85 procent van de gevallen boven de 3.000 gulden netto per maand, met het zwaartepunt tussen 3.000 en 6.000 gulden. Dit is te verklaren doordat meer dan 80 procent van de partners van de niet-participerenden een betaalde voltijdbaan heeft. Toch geeft nog 5 procent van de niet-participerenden aan een huishoudinkomen van 0 gulden per maand te hebben ${ }^{5}$.

Voor de totale groep niet-participerenden met een partner geldt dat de partner gemiddeld genomen voor 83 procent van het netto huishoudinkomen

5. Deze groep van niet-participerenden wil waarschijnlijk geen opgave van de inkomensgegevens doen. 
verantwoordelijk is. Er lijkt dus sprake te zijn van duidelijk afgebakende rollen binnen het huishouden: de werkende, mannelijke partner genereert het inkomen en de vrouwelijke niet-participerende apothekersassistent zorgt voor het huishouden en de (eventueel aanwezige) kinderen.

Tabel 3.4

Netto maandinkomen van niet-participerenden, 2001

\section{Netto maandinkomen}

Persoonlijk inkomen in guldens (euro's)

0

$1-999(1-453)$

1000-1999 (454-907)

2000-2999 (908-1361)

3000-3999 (1361-1815)

4000-4999 (1815-2268)

5000-5999 (2269-2722)

6000 of hoger (2723- )

Totaal

Huishoudinkomen in guldens (euro's) 0

$1-999(1-453)$

$1000-1999(454-907)$

2000-2999 (908-1361)

3000-3999 (1361-1815)

4000-4999 (1815-2268)

5000-5999 (2269-2722)

6000 of hoger (2723- )

Totaal

Bron: ROA

Het inkomen van de werkende partner neemt veelal de noodzaak tot het verrichten van betaald werk weg, terwijl tegelijkertijd de prioriteit van het grootbrengen van kinderen de mogelijkheid van betaald werk minder gewenst maakt. De huishoudsituatie van veel niet-participerende apothekersassistenten leidt er vaak toe dat men noch betaald werk hoeft te verrichten, noch wenst te verrichten.

\section{Arbeidsverleden}

Voor het inzicht in de werkervaring en het aantal jaren inactiviteit, wordt tevens ingegaan op het arbeidsverleden. Om te beginnen wordt gekeken naar het laatste beroep van de niet-participerende apothekersassistenten. Figuur 3.2 laat zien dat 77 procent het beroep van apothekersassistent heeft uitgeoefend in de laatste baan. Bijna een kwart heeft voor uittrede van de arbeidsmarkt nog in een ander beroep gewerkt. Slechts 5 procent van de niet-participerende apothekersassistenten heeft voor de arbeidsmarktuittrede in een beroep elders in de gezondheidszorg gewerkt.

Een tweede aspect van het arbeidsverleden van niet-participerenden heeft betrekking op het laatste jaar dat men heeft gewerkt. Het aantal jaren inactiviteit kan een indicatie zijn van de mate waarin de vaardigheden zijn afgenomen doordat ze niet gebruikt zijn. Meer algemene kennis en vaardigheden kunnen echter ook in andere 
beroepen dan apothekersassistent worden onderhouden. De veroudering van kennis en vaardigheden die specifiek voor het beroep van apothekersassistent benodigd zijn, kan optreden doordat de specifieke kennis en vaardigheden niet gebruikt worden, of doordat zich nieuwe beroepsspecifieke ontwikkelingen hebben voorgedaan die on-the-job training of bijscholing vereisen.

Figuur 3.2

Laatste beroep van niet-participerenden, 2001

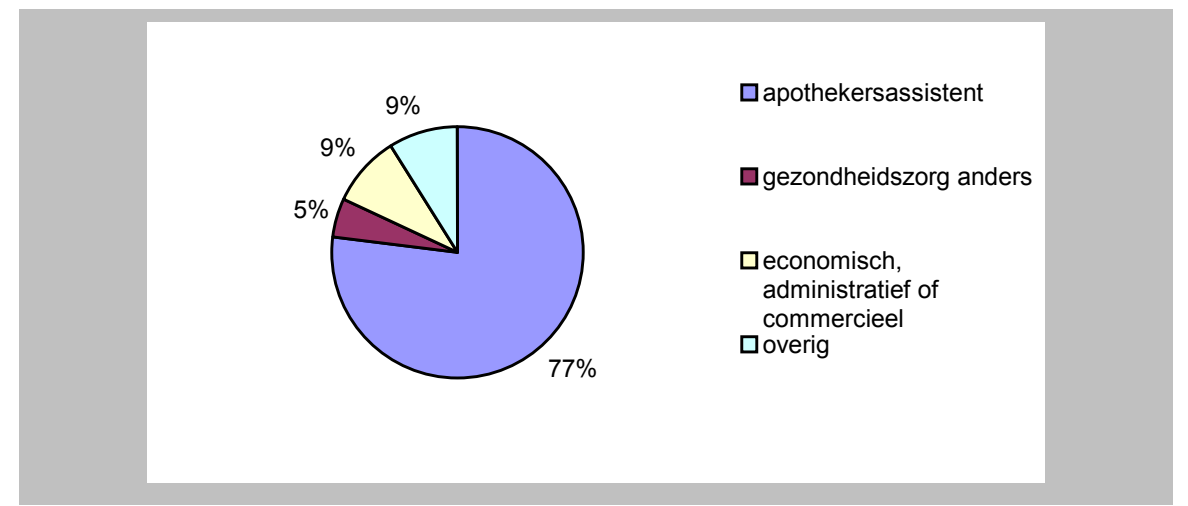

Bron: ROA

Tabel 3.5 toont het laatste jaar waarin apothekersassistenten in de openbare apotheek hebben gewerkt. 46 procent heeft voor het laatst vóór 1995 betaald werk in de openbare apotheek verricht. Deze groep van niet-participerenden is ruim 6 jaar niet meer actief geweest in de openbare apotheek. Indien deze groep zich opnieuw als apothekersassistent op de arbeidsmarkt wil aanbieden, zal waarschijnlijk enige herscholing gewenst zijn. Zoals aangegeven in figuur 3.3 was een baan als apothekersassistent voor bijna driekwart van de niet-participerenden ook meteen de laatste baan voordat ze stopten met werken.

Tabel 3.5

Laatste arbeidsjaar als apothekersassistent in de openbare apotheek van niet-participerenden, 2001

Laatste arbeidsjaar

1975-1979

1980-1984

1985-1989

1990-1994

1995-1999

2000

Totaal

Bron: ROA

Om een beeld te krijgen van de kwaliteit van het onbenutte arbeidspotentieel van niet-participerende apothekersassistenten is het tevens relevant om na te gaan hoe 
lang geleden het diploma tot apothekersassistent is behaald. Tabel 3.6 geeft een overzicht van het diplomajaar van de niet-participerende apothekersassistenten. Voor meer dan 80 procent van de niet-participerenden geldt dat zij de opleiding tot apothekersassistent langer dan tien jaar geleden hebben afgerond. Voor ongeveer een vijfde geldt zelfs dat het diploma voor de opleiding tot apothekersassistent al vóór 1975 werd behaald. In veel gevallen duidt een dergelijke termijn op een aanzienlijke veroudering van beroepsspecifieke kennis en vaardigheden, omdat gemiddeld slechts 55 procent na 1994 nog heeft gewerkt als apothekersassistent in een openbare apotheek.

Tabel 3.6

Diplomajaar van niet-participerenden en percentage dat na 1994 nog heeft gewerkt als apothekersassistent (AA) in de openbare apotheek (OA), 2001

\begin{tabular}{lrr}
\hline Diplomajaar & \multicolumn{3}{c}{$\begin{array}{c}\text { waarvan gewerkt } \\
\text { als AA in OA na } \begin{array}{c}1994 \\
\%\end{array}\end{array}$} \\
\hline $1960-1964$ & \multicolumn{2}{c}{56} \\
$1965-1969$ & 10 & 38 \\
$1970-1974$ & 6 & 33 \\
$1975-1979$ & 14 & 32 \\
$1980-1984$ & 26 & 40 \\
$1990-1989$ & 21 & 73 \\
$1995-1994$ & 8 & 94 \\
2000 & 7 & 400 \\
Totaal & 1 & 55 \\
\hline
\end{tabular}

Bron: ROA

Behalve het diplomajaar van de opleiding tot apothekersassistent is echter ook de zogenaamde post-initiële scholing van belang. Deze scholing kan worden gevolgd om bij te blijven in het vakgebied, en kan daarmee de veroudering van kennis en vaardigheden tegengaan. Ook kan post-initiële scholing worden gevolgd om de horizon te verbreden, eventueel in verband met een volgende carrièrestap. Veel nietparticiperenden (42 procent) hebben na hun opleiding tot apothekersassistent nog een andere opleiding gevolgd. Ruim viervijfde heeft daadwerkelijk een diploma behaald. De laatst gevolgde opleiding waarvoor een diploma is behaald was vaak (36 procent) een farmaceutische opleiding op middelbaar beroepsniveau. Toch heeft 14 procent een diploma op HBO-niveau en 2 procent een diploma op WO-niveau weten te behalen.

Tabel 3.7 geeft voor de niet-participerenden aan hoeveel jaren werkervaring als apothekersassistent zij hebben. Ruim tweederde van de niet-participerenden heeft tussen 6 en 15 jaar werkervaring als apothekersassistent. Het aandeel vijftigplussers in deze groep is relatief klein. Voor de niet-participerende apothekersassistenten met meer dan 15 jaar werkervaring neemt het aandeel vijftigplussers snel toe naarmate het aantal jaren werkervaring toeneemt. De groep met weinig werkervaring is relatief klein: 11 procent heeft 5 jaar of minder aan werkervaring als apothekersassistent, en ongeveer de helft daarvan heeft minder dan 3 jaar werkervaring. 
Tabel 3.7

Werkervaring als apothekersassistent van niet-participerenden, 2001

\begin{tabular}{lrr}
\hline Werkervaring in jaren & & $\begin{array}{r}\text { waarvan leeftijd } \\
50 \text { jaar of ouder } \\
\%\end{array}$ \\
& $\%$ & \\
\hline $0-5$ & 12 & 4 \\
$6-10$ & 37 & 4 \\
$1-15$ & 31 & 26 \\
$16-20$ & 12 & 55 \\
$21-25$ & 5 & 63 \\
$26-30$ & 1 & 100 \\
meer dan 30 & 1 & 19 \\
Totaal & 100 & \\
\hline
\end{tabular}

Bron: ROA

Uit het bovenstaande blijkt dat de niet-participerende apothekersassistenten veelal een opleiding tot apothekersassistent hebben genoten ruim voor 1995, sindsdien een aanzienlijke werkervaring (meer dan 5 jaar) als apothekersassistent hebben opgedaan en bovendien vaak nog een vervolgopleiding hebben gevolgd, maar tevens vaak al meer dan vijf jaar niet meer gewerkt hebben in de openbare apotheek. Onder degenen met een werkervaring tussen 5 en 15 jaar is slechts een klein deel vijftig jaar of ouder.

\section{Redenen van uittrede}

Hierboven is gebleken dat voor ruim driekwart van de niet-participerenden geldt dat de laatste baan voor de uittrede die van apothekersassistent was, hetgeen de vraag oproept wat de aanleiding was voor de uittrede. Tabel 3.8 laat zien welke de belangrijkste redenen waren om te stoppen met het werk in de openbare apotheek.

Tabel 3.8

Reden van uittrede uit de openbare apotheek, niet-participerenden, 2001

Reden

Zorg voor kinderen, huishoudelijk werk of andere zorgtaken

Te weinig faciliteiten voor kinderopvang of buitenschoolse opvang

Studie

Gezondheid

Reistijd naar het werk was te groot

Werk was niet leuk genoeg

Hoge werkdruk

Werk bood te weinig carrièreperspectief

Werk was financieel niet aantrekkelijk genoeg

Te weinig mogelijkheden voor deeltijdwerk

Te weinig mogelijkheden voor flexibele werktijden

Onregelmatige diensten

Onvrijwillig werkloos geworden

Overig

Totaal

Bron: ROA 
Het verrichten van huishoudelijk werk of zorgtaken was voor de niet-participerende apothekersassistenten veruit de belangrijkste reden voor uittrede. Maar liefst de helft is om deze reden gestopt met het werk als apothekersassistent in de openbare apotheek. Deze reden is sterk gerelateerd aan de veranderingen in de persoonlijke en huishoudsituatie door het krijgen van een partner en kinderen. Bovendien blijkt een eventueel gebrek aan kinderopvang of buitenschoolse opvang geen rol te spelen bij de beslissing om uit te treden. Andere persoonlijke redenen zijn de keuze voor studie en gezondheidsredenen ${ }^{6}$. Ook een te grote reistijd naar het werk kan als een persoonlijke reden voor uittrede beschouwd worden. Dit betekent dat in totaal ongeveer 60 procent van de redenen voor uittrede gebaseerd is op persoonlijke omstandigheden of motieven.

Tabel 3.8 laat voorts zien dat er verschillende redenen voor uittrede waren die aan het werk van apothekersassistenten gerelateerd zijn. Hier gaat het dan met name erom dat het werk niet leuk werd gevonden of dat er een te hoge werkdruk heerste. Andere redenen voor uittrede die te maken hebben met de arbeidsvoorwaarden of de functievervulling zijn te weinig carrièreperspectief, te geringe financiële aantrekkelijkheid, te weinig mogelijkheden voor deeltijdwerk of flexibele werktijden. In totaal waren deze werkgerelateerde redenen voor ruim een vijfde van de nietparticiperende apothekersassistenten de belangrijkste reden voor uittrede. Tot slot is 3 procent uitgetreden omdat men onvrijwillig werkloos werd, en heeft 14 procent een andere reden voor uittrede gehad.

Zoals opgemerkt was voor ruim de helft van de niet-participerenden het verrichten van huishoudelijk werk en zorgtaken de belangrijkste reden voor uittrede, hetgeen aansluit bij de eerdere constatering dat tweederde van de niet-participerenden dat ook als belangrijkste bezigheid ziet. Het lijkt er echter wel op dat meer nietparticiperenden dan degenen die oorspronkelijk het verrichten van huishoudelijk werk en zorgtaken als belangrijkste reden voor uittrede hadden, deze werkzaamheden nu als voornaamste bezigheid zijn gaan zien. $\mathrm{Na}$ de arbeidsmarktuittrede van de werkende, meestal vrouwelijke apothekersassistent is de traditionele taakverdeling tussen de buitenshuis werkende man en de binnenshuis werkende vrouw waarschijnlijk nog belangrijker geworden in veel huishoudens.

\section{Bereidheid tot herintrede in de openbare apotheek}

In het voorafgaande zijn de niet-participerende apothekersassistenten gekarakteriseerd op basis van onder meer hun huishoudsituatie, leeftijd, werkervaring en inactiviteitsduur. Naast deze objectieve achtergrondkenmerken van niet-participerenden, is ook de door hen geuite bereidheid tot herintrede minstens zo belangrijk.

Figuur 3.3 geeft aan in welke mate niet-participerenden bereid zijn om betaald werk als apothekersassistent in de openbare apotheek te accepteren, en of aan herintrede nog voorwaarden worden gesteld.

6. De groep die om gezondheidsredenen is uitgetreden is overigens verantwoordelijk voor $59 \%$ van de arbeidsongeschikte niet-participerenden. 
Figuur 3.3

Bereidheid van niet-participerenden om te werken als apothekersassistent in de openbare apotheek, 2001

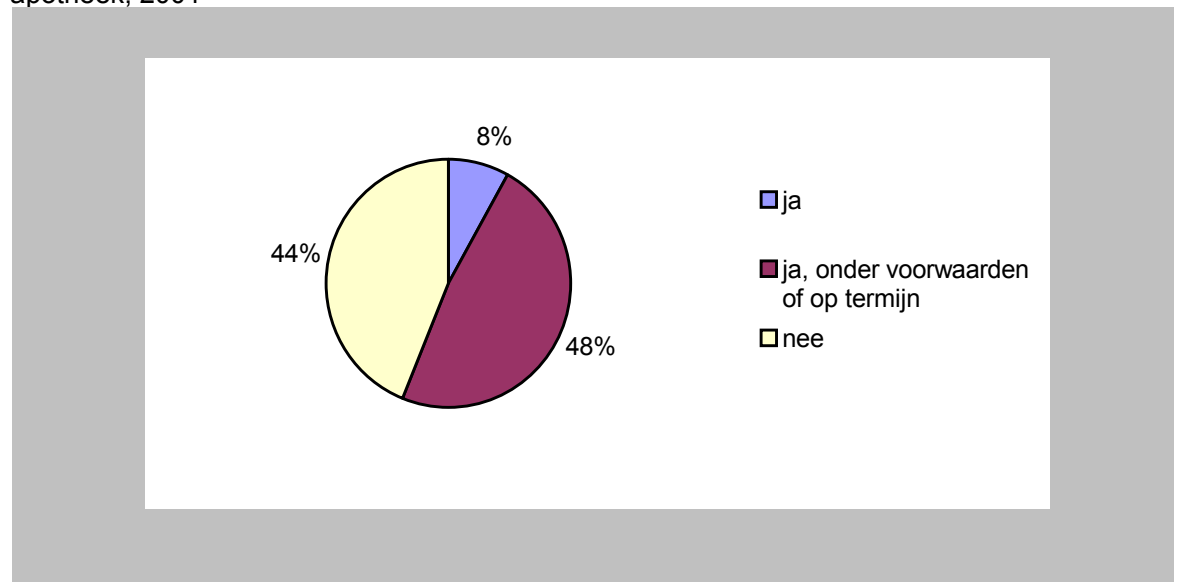

Bron: ROA

Slechts 8 procent is bereid weer als apothekersassistent in de openbare apotheek aan de slag te gaan zonder hieraan voorwaarden te verbinden, terwijl 48 procent wel voorwaarden verbindt aan een eventuele herintrede. De eerste relatief kleine groep is derhalve absoluut bereid, de tweede beduidend grotere groep is zogenaamd voorwaardelijk bereid om terug te keren naar de openbare apotheek ${ }^{7}$. Dit wijst op het grote belang dat bereidwillige potentiële herintreders hechten aan de omstandigheden waaronder een eventuele terugkeer naar de openbare apotheek wordt overwogen. Toch wil 44 procent helemaal niet terugkeren als apothekersassistent in een openbare apotheek.

Hieronder wordt verder ingegaan op de mogelijke voorwaarden waaronder de potentiële herintreders in de openbare apotheek willen gaan werken. Dit wordt gedaan door te kijken naar de wensen van potentiële herintreders die voorwaarden verbinden aan de herintrede ten opzichte van hen die geen voorwaarden stellen of niet bereid zijn om weer in dienst te treden bij de openbare apotheek.

In tabel 3.9 is een overzicht gegeven van de vele belemmeringen die potentiële herintreders kunnen ervaren bij een eventuele terugkeer. Deze potentiële herintreders zijn onderverdeeld naar bereidheid. De tabel geeft weer hoeveel procent van de niet-participerenden een bepaalde belemmering ervaart. Het blijkt dat de zorg voor de kinderen, huishoudelijk werk of andere zorgtaken veruit de belangrijkste belemmering vormt voor herintrede. Dit sluit goed aan bij de eerdere bevindingen dat de meestal vrouwelijke voormalige apothekersassistenten veelal een jong gezin hebben waarin de man de kost verdient. De zorg voor de kinderen, huishoudelijk werk of andere zorgtaken is voor 81 procent van degenen die voorwaardelijk bereid

7. Hierna zal blijken dat 'absolute bereidheid' niet wil zeggen dat er geen voorwaarden zijn bij een eventuele terugkeer. Het ligt echter voor de hand dat de niet-participerenden die absoluut tot herintrede bereid zijn, minder stringente voorwaarden hebben. 
zijn tot herintrede van belang, hetgeen nog aanzienlijk hoger is dan voor de nietparticiperenden van de overige twee groepen. Dit kan erop duiden dat deze groep specifieke voorwaarden stelt in verband met bijvoorbeeld kinderopvang of de termijn waarop herintrede gewenst is, bijvoorbeeld als de kinderen ouder zijn. Verder blijkt dat men de afgenomen kennis en vaardigheden voor het werk als apothekersassistent als een mogelijke belemmering ziet, en dat veel mensen die zonder meer terug willen keren naar openbare apotheek worden belemmerd door hun gezondheid.

Tabel 3.9

Belemmeringen naar bereidheid tot herintrede als apothekersassistent (AA) in de openbare apotheek (OA), niet-participerenden, 2001

\begin{tabular}{|c|c|c|c|}
\hline Belemmering & $\begin{array}{r}\text { absoluut } \\
\text { bereid } \\
\%\end{array}$ & $\begin{array}{c}\text { voorwaardelijk } \\
\text { bereid } \\
\%\end{array}$ & $\begin{array}{r}\text { niet } \\
\text { bereid } \\
\%\end{array}$ \\
\hline \multicolumn{4}{|l|}{ Zorg voor kinderen, huishoudelijk } \\
\hline werk of andere zorgtaken & 67 & 81 & 52 \\
\hline Geen behoefte aan betaald werk & 3 & 7 & 18 \\
\hline Studie & 4 & 3 & 10 \\
\hline Kennis en vaardigheden aanzienlijk afgenomen & 13 & 14 & 19 \\
\hline Gezondheid & 19 & 8 & 11 \\
\hline Financieel onaantrekkelijk & 15 & 21 & 18 \\
\hline Reistijd naar het werk & 13 & 12 & 2 \\
\hline Te weinig deeltijdmogelijkheden & 24 & 34 & 8 \\
\hline Te weinig flexibele werktijden & 47 & 52 & 12 \\
\hline \multicolumn{4}{|l|}{ Te weinig faciliteiten voor kinderopvang } \\
\hline of buitenschoolse opvang & 20 & 26 & 5 \\
\hline Te veel onregelmatige diensten & 13 & 25 & 18 \\
\hline Hoge werkdruk & 16 & 18 & 20 \\
\hline Werk als AA minder leuk dan ander werk & 0 & 3 & 18 \\
\hline Werk in OA minder leuk dan elders & 0 & 2 & 8 \\
\hline Te weinig carrièreperspectief & 5 & $1 \overline{1}$ & 19 \\
\hline Geen geschikt werk (als AA in OA) gevonden & 8 & 4 & 1 \\
\hline
\end{tabular}

Uit tabel 3.9 blijkt verder dat de arbeidsvoorwaarden bij herintrede een rol spelen. Van groot belang zijn vooral flexibele werktijden, maar ook het werken in deeltijd en de faciliteiten voor kinderopvang en buitenschoolse opvang. Daarnaast kunnen onregelmatige diensten, de hoge werkdruk en de financiële onaantrekkelijkheid belangrijke belemmeringen zijn bij herintrede. Vooral voor degenen die onder voorwaarden terug willen keren zijn te weinig deeltijdmogelijkheden en te veel onregelmatige diensten belangrijkere belemmeringen dan voor degenen die absoluut bereid zijn tot herintrede. Dit wijst erop dat de arbeidsvoorwaarden die hiermee verband houden potentiële herintreders over de streep kunnen trekken om terug te keren naar de openbare apotheek.

Van degenen die niet bereid zijn om weer aan de slag te gaan als apothekersassistent in de openbare apotheek, ook niet onder bepaalde voorwaarden of op termijn, geeft ruim de helft huishoudelijk werk of zorgtaken als reden op. Zoals verwacht mag worden heeft een deel van hen geen behoefte aan betaald werk, terwijl werkgerelateerde redenen zoals reistijd, flexibele werktijden, deeltijdwerk, en kinderopvang veel minder van belang zijn. Opvallend is verder dat de mensen in 
deze groep veel vaker dan degenen die bereid zijn tot herintrede, het werk als apothekersassistent of het werk in de openbare apotheek minder leuk vinden. Ook het ontbreken van carrièreperspectief wordt veel vaker genoemd.

Hierboven is gebleken dat de mogelijkheid voor het werken in deeltijd een belangrijke voorwaarde kan zijn voor apothekersassistenten bij herintrede. Dit aspect lijkt mede gezien het grote aantal vrouwen dat huishoudelijke taken verricht en grotendeels voor de kinderen zorgt, van bijzonder belang. Tabel 3.10 geeft aan hoeveel uren per week bereidwillige niet-participerenden willen werken. Het blijkt dat 56 procent een baan wil van 9 tot maximaal 16 uur per week, terwijl 29 procent een baan wil van 17 tot maximaal 24 uur per week. Van de niet-participerenden die voorwaarden stellen aan hun terugkeer naar de openbare apotheek wil echter 70 procent een baan van 9 tot maximaal 16 uur per week. Dit betekent dat het werken in kleine deeltijdbanen tot maximaal 16 uur per week een belangrijke voorwaarde is voor veel potentiële herintreders om terug te keren naar de openbare apotheek.

Tabel 3.10

Gewenste aantal uren betaald werk per week van niet-participerenden die absoluut of onder voorwaarden bereid zijn tot herintrede in de openbare apotheek, 2001

\begin{tabular}{lrr}
\hline Aantal uren per week & $\begin{array}{r}\text { absoluut } \\
\text { bereid }\end{array}$ & $\begin{array}{r}\text { voorwaardelijk } \\
\text { bereid }\end{array}$ \\
\hline $1-8$ & 8 & 6 \\
$9-16$ & 56 & 70 \\
$17-24$ & 29 & 20 \\
$25-32$ & 3 & 2 \\
meer dan 32 & 4 & 2 \\
Totaal & 100 & 100 \\
\hline
\end{tabular}

Bron: ROA

Tabel 3.11 geeft nog verschillende andere voorwaarden aan die van belang kunnen zijn bij de overweging tot terugkeer naar de openbare apotheek. Ruim de helft van de apothekersassistenten die zonder meer bereid zijn terug te keren, is echter niet binnen vier weken beschikbaar. Dit is zelfs bijna driekwart voor degenen die voorwaarden verbinden aan hun herintrede. De termijn waarop potentiële herintreders terug willen of kunnen keren, blijkt dus van groot belang te zijn.

In tabel 3.9 is al gebleken dat flexibele werktijden erg belangrijk zijn voor potentiële herintreders. Uit tabel 3.11 blijkt dat ruim 90 procent een functie sneller zou accepteren indien er voldoende mogelijkheden zijn om de werktijden flexibel in te delen. Daarnaast is de maximaal acceptabele reistijd van thuis naar het werk (enkele reis) van groot belang. Deze ligt voor ruim de helft van de werkwillige niet-participerenden op 20 minuten of minder, hetgeen betekent dat het werk in de nabije omgeving moet liggen. Dit percentage ligt nog hoger voor degenen die voorwaarden aan herintrede verbinden. De beschikbaarheid en de kosten van kinderopvang en buitenschoolse en het volgen van een opfriscursus spelen eveneens een rol bij herintrede, maar vallen niet onder de bijzondere voorwaarden die potentiële 
herintreders over de streep kunnen trekken om terug te keren. Waarschijnlijk is bij velen bekend dat de faciliteiten voor de opvang van kinderen en voor het volgen van cursussen over het algemeen goed zijn bij de openbare apotheek. Deze faciliteiten spelen zeker een rol bij de herintrede, maar naar verwachting zal slechts een beperkt aantal potentiële herintreders ervaren dat de faciliteiten toch onvoldoende zijn bij herintrede.

Tabel 3.11

Voorwaarden van de niet-participerenden die bereid zijn tot herintrede in de openbare apotheek, 2001

\begin{tabular}{lrr}
\hline Voorwaarde & $\begin{array}{r}\text { absoluut } \\
\text { bereid } \\
\%\end{array}$ & $\begin{array}{r}\text { voorwaardelijk } \\
\text { bereid } \\
\%\end{array}$ \\
\hline Niet beschikbaar binnen vier weken & 54 & 73 \\
Sneller functie accepteren bij flexibele werktijden & 92 & 93 \\
Acceptabele enkele reistijd 20 minuten of minder & 53 & 61 \\
Beschikbaarheid van kinderopvang of buitenschoolse opvang* & 57 & 48 \\
Kosten van kinderopvang of buitenschoolse opvang* & 61 & 51 \\
Opfriscursus noodzakelijk bij herintrede & 73 & 65
\end{tabular}

* Voor niet-participerenden met een kind jonger dan 12 jaar.

Bron: ROA

In tabel 3.12 is verder weergegeven welk type opfriscursus noodzakelijk wordt geacht om weer als apothekersassistent aan de slag te gaan. Een cursus over geneesmiddelenkennis wordt duidelijk het meest belangrijk gevonden. Ook de genoemde andere cursussen, met uitzondering van een cursus communicatieve vaardigheden en omgangskunde, en een stage worden van belang geacht.

Tabel 3.12

Percentage van de niet-participerenden* dat bij herintrede een bepaalde opfriscursus noodzakelijk vindt, 2001

Type

Geneesmiddelenkennis

Informatieverstrekking over geneesmiddelen

Computervaardigheden

Recepteren en bereiden van geneesmiddelen

Stage

Kennis van ziektebeelden

Communicatieve vaardigheden en omgangskunde

* Uitsluitend de niet-participerenden die een opfriscursus noodzakelijk vinden bij herintrede. Bron: ROA

Uit tabel 3.9 is tevens gebleken dat voor ongeveer een vijfde van de nietparticiperenden het financieel onaantrekkelijk is om terug te keren naar de openbare apotheek. Dit hoeft niet per se betrekking te hebben op de salariëring als apothekersassistent in de openbare apotheek, maar kan ook liggen aan het hoge inkomen van de partner in combinatie met het belastingstelsel. In de bespreking van de huishoudsituatie is reeds aan de orde gekomen dat het inkomen van de partner de 
noodzaak van de niet-participerenden om te gaan werken vermindert. De voorlopige conclusie was dat in veel gevallen verwacht mag worden dat het inkomen van de partner zodanig hoog is dat veel niet-participerenden, gegeven hun huishoudelijke en zorgtaken, niet snel geneigd zijn zich aan te bieden op de arbeidsmarkt om betaald werk te verrichten. Tabel 3.13 geeft voor de bereidwillige niet-participerenden aan hoe hoog het netto maandloon moet zijn om voor het gewenste aantal uren aan de slag te gaan. Er lijkt in eerste instantie weinig verschil te zijn tussen de salariswensen van niet-participerenden die wel en geen voorwaarden stellen aan hun herintrede. Ongeveer driekwart wenst een loon tussen 1000 en 2000 gulden netto per maand te verdienen bij herintrede.

Tabel 3.13

Gewenste netto maandloon van niet-participerenden die bereid zijn tot herintrede in de openbare apotheek, 2001

\begin{tabular}{lrr}
\hline Gewenst netto maandloon in guldens (euro's) & $\begin{array}{r}\text { absoluut } \\
\text { bereid } \\
\%\end{array}$ & $\begin{array}{r}\text { voorwaardelijk } \\
\text { bereid } \\
\%\end{array}$ \\
\hline $0-999(1-453)$ & 8 & 10 \\
$1000-1999(454-907)$ & 75 & 76 \\
$2000-2999(908-1361)$ & 13 & 12 \\
$3000-3999(1361-1815)$ & 4 & 1 \\
$4000-4999(1815-2268)$ & 0 & 0 \\
$5000-5999(2269-2722)$ & 0 & 0 \\
6000 of hoger (2723- ) & 0 & 100 \\
Totaal & 100 & \\
\hline
\end{tabular}

Bron: ROA

Tabel 3.14

Gewenste netto uurloon van niet-participerenden die bereid zijn tot herintrede in de openbare apotheek, 2001

\begin{tabular}{lrr}
\hline Gewenste netto uurloon in guldens (euro's) & $\begin{array}{r}\text { absoluut } \\
\text { bereid } \\
\%\end{array}$ & $\begin{array}{r}\text { voorwaardelijk } \\
\text { bereid } \\
\%\end{array}$ \\
\hline $6-10(2,72-4,54)$ & 4 & 3 \\
$11-15(4,99-6,81)$ & 15 & 9 \\
$16-20(7,26-9,08)$ & 36 & 44 \\
$21-25(9,53-11,34)$ & 27 & 36 \\
$26-30(11,80-13,61)$ & 13 & 9 \\
meer dan $30(13,61-)$ & 5 & 3 \\
Totaal & 100 & 100 \\
\hline
\end{tabular}

Bron: ROA

Voor een beter beeld van het gewenste loon is tevens gekeken naar het gewenste netto uurloon. Dit gegeven is verkregen door het gewenst netto loon per maand te corrigeren voor het gewenste aantal uren per week. De gewenste netto uurlonen zijn weergegeven in tabel 3.14. De meeste niet-participerenden willen een netto loon van 16 tot 25 gulden per uur. Van degenen die voorwaarden stellen aan hun herintrede wenst 80 procent een dergelijk loon. Onder degenen die voorwaarden stellen is de 
spreiding in gewenst netto uurloon minder groot, hetgeen erop kan wijzen dat zij beter weten wat ze kunnen en willen verdienen bij een eventuele herintrede.

De gewenste uurlonen van 16 tot 25 gulden komen redelijk goed overeen met wat een apothekersassistent met 10 dienstjaren volgens de CAO zou moeten verdienen. Uitgaande van 4.000 gulden bruto per maand op basis van 36 uur, bedraagt het netto uurloon ongeveer 20 gulden. Het netto uurloon valt door het belastingstelsel in principe hoger uit voor kleinere deeltijdbanen, van bijna 18 gulden bij een 36-urige werkweek tot 24 gulden bij een 12-urige werkweek ${ }^{8}$. Een uurloon van meer dan 25 gulden lijkt alleen reëel voor de niet-participerenden die bijvoorbeeld door hun werkervaring, nascholing en relatief korte inactiviteitsduur, een aanzienlijk betere arbeidsmarktpositie dan gemiddeld hebben.

Over het algemeen kan gesteld worden dat een ruime meerderheid van nietparticiperenden die bereid is terug te keren naar de openbare apotheek, maar daar wel verschillende voorwaarden aan verbindt. Van belang is natuurlijk dat velen niet op korte termijn (binnen een maand) beschikbaar zijn, en dat daarbij het huishoudelijk werk en de zorgtaken een obstakel vormen. Verder willen de potentiële herintreders in deeltijd werken, velen zelfs maar maximaal 16 uur of hooguit 24 uur. Andere arbeidsvoorwaarden die potentiële herintreders kunnen 'verleiden' terug te keren naar de openbare apotheek hebben betrekking op het aanbieden van flexibele werktijden en het vermijden van onregelmatige diensten.

\section{Imago van de beroepsgroep en de opleiding}

Het imago dat de beroepsgroep van apothekersassistenten heeft, kan van belang zijn bij de afweging of iemand wil terugkeren. Zoals in tabel 3.9 duidelijk werd, vinden vooral degenen die niet bereid zijn terug te keren als apothekersassistent naar de openbare apotheek het werk minder leuk dan ander werk, of vinden zij dat het werk te weinig carrièreperspectief biedt. Aan de ene kant hebben bijna alle potentiële herintreders (94 procent) voorheen het werk als apothekersassistent met plezier gedaan. Aan de andere kant zou toch bijna de helft (45 procent) achteraf gezien een andere opleiding hebben gekozen. Deze groep heeft dus in feite spijt van de opleidingskeuze voor apothekerassistent. In tabel 3.15 wordt duidelijk wat hiervan de redenen kunnen zijn. Meer dan helft noemt als reden dat het werk als apothekersassistent financieel niet aantrekkelijk is. Een mogelijke hiermee samenhangende reden die ook meer dan de helft noemt, is dat het werk als apothekersassistent te weinig carrièreperspectief biedt. Verder zijn ook de hoge werkdruk en de onregelmatige diensten belangrijke redenen waarom men spijt heeft van de opleidingskeuze. Opvallend is dat de opleiding tot apothekersassistent als zodanig door een hele kleine groep negatief wordt beoordeeld.

8. Bij de berekening van de netto uurlonen is uitgegaan van tariefgroep 2 (i.e. met basis- en bovenbasisaftrek) in het belastingstelsel voor de belastingherziening, waarbij verder geen aftrekposten zijn verondersteld. $\mathrm{Er}$ is geen rekening gehouden met het eventuele belastingnadeel vanwege de lagere basisaftrek van de partner als zijn vrouw boven de drempel van 8.523 gulden $(€ 3868)$ gaat verdienen. 
Het zijn dus vooral aspecten in verband met het beroep van apothekersassistent die het gevoel van een verkeerde opleidingskeuze veroorzaken.

Tabel 3.15

Redenen waarom niet-participerenden achteraf gezien niet voor de opleiding tot apothekersassistent gekozen zouden hebben, 2001

Reden van spijt

$\%$

Opleiding niet interessant

5

Andere opleidingen sluiten beter aan

4

Niets of weinig aan opleiding gehad

2

Werk als AA niet leuk

Werk biedt weinig carrièreperspectief

Werk financieel niet aantrekkelijk

52

Onregelmatige diensten

Hoge werkdruk

Overige arbeidsvoorwaarden niet aantrekkelijk

Overige redenen

Bron: ROA

Bij de niet-participerenden die een terugkeer naar de openbare apotheek overwegen, gaat het vooral om de positieve aspecten die zij in hun werk zien. Op deze positieve aspecten kan worden ingespeeld door werkgevers. Uit tabel 3.16 blijkt dat potentiële herintreders vooral hechten aan de inhoudelijke aspecten van het werk, zoals de kennis en bereiding van geneesmiddelen. Ook de dienstverlening aan klanten en de werksfeer zijn positieve aspecten van het werken in de openbare apotheek. Aspecten die met de verantwoordelijkheid en de zelfstandigheid te maken hebben, worden in het algemeen iets minder gewaardeerd. Verder is duidelijk dat de arbeidsvoorwaarden van apothekersassistenten in de openbare apotheek geen aansprekende redenen zijn voor een eventuele terugkeer.

Tabel 3.16

Aantrekkelijkheid van het werk als apothekersassistent voor niet-participerenden die terug willen keren naar de openbare apotheek, 2001

Werkaspect

Kennis van geneesmiddelen, ziekte en gezondheid 78

Bereiding van geneesmiddelen

Verantwoordelijkheid

Zelfstandigheid

Dienstverlening aan klanten $\quad 76$

Werksfeer

Financiële aantrekkelijkheid

Aantrekkelijkheid overige arbeidsvoorwaarden

Overige

Geen

Bron: ROA 
De beroepsgroep van apothekersassistenten kan wat betreft het imago bouwen op inhoudelijk interessant werk, met veel aandacht voor de kennis en bereiding van geneesmiddelen. Verder worden de dienstverlening met klanten en de prettige werksfeer op prijs gesteld. Toch heeft bijna de helft spijt de opleiding ooit te hebben gevolgd, ondanks dat de opleiding als zodanig niet negatief wordt beoordeeld. Het imago van het beroep van apothekersassistenten lijkt te lijden onder het beeld van onaantrekkelijke salariëring en overige arbeidsvoorwaarden, en een gebrek aan carrièreperspectief. 



\section{De werkloze apothekersassistenten}

In dit hoofdstuk wordt verder ingegaan op de achtergrondkenmerken van werkloze apothekersassistenten en hun bereidheid tot terugkeer naar de openbare apotheek. Zij zijn naar eigen zeggen werkloos ${ }^{9}$. Uit hoofdstuk 2 is reeds gebleken dat er ongeveer 1.000 werklozen zijn. Ruim de helft van de werklozen is vijftig jaar of ouder en vrijwel alle werklozen zijn vrouw. In dit hoofdstuk wordt vooral gekeken naar de achtergrondkenmerken en de factoren in verband met de bereidheid tot terugkeer naar de openbare apotheek, met name voor zover werklozen zich onderscheiden ten opzichte van niet-participerenden. Wat naar verwachting een belangrijk onderscheid is tussen de werklozen en de niet-participerenden, is de grotere bereidheid van de werklozen om weer aan het werk te gaan. Vandaar dat ook wordt gekeken naar hun zoekgedrag ten aanzien van het vinden van een baan. Dit hoeft uiteraard niet te betekenen dat zij weer een baan als apothekersassistent in de openbare apotheek willen hebben.

\section{Huishoudsituatie}

In tabel 4.1 is weergegeven in welke mate werkloze apothekersassistenten een partner en/of thuiswonende kinderen hebben. Evenals de niet-participerenden hebben ook de werklozen in grote meerderheid een partner, hoewel er duidelijk meer alleenstaanden zijn onder de werklozen dan onder niet-participerenden (15 procent versus 9 procent). Verder valt op dat de werklozen aanmerkelijk minder vaak thuiswonende kinderen hebben. Meer dan de helft van alle werkloze apothekersassistenten heeft zelfs helemaal geen thuiswonende kinderen. Voor de werklozen zonder partner is dit percentage 81 procent, maar ook van de werklozen met een partner heeft 'slechts' 53 procent minimaal één thuiswonend kind.

Voor de kans op werkhervatting van de werkloze apothekersassistenten kan tevens de leeftijd van het jongste thuiswonende kind van belang zijn. In tabel 4.2 is te zien dat met name het aandeel werklozen met kinderen tussen 20 en 24 jaar oud veel groter is dan bij de niet-participerenden, terwijl het aandeel werklozen met drie- en vierjarige kinderen daarentegen kleiner is dan bij de niet-participerenden. Niet alleen geldt dus dat de werklozen minder kinderen hebben dan de niet-participerenden, daarnaast zijn deze kinderen vaker in een leeftijd dat zij minder verzorging vereisen.

9. Dit criterium is anders dan de door het CBS gehanteerde criteria voor de 'werkloze beroepsbevolking', dat in hoofdstuk 2 werd gehanteerd om het aantal werkloze apothekersassistenten te bepalen. Om door het CBS als werkloze te worden beschouwd, dient men geen werk te hebben van 12 uur per week of meer, op zoek te zijn naar een baan van minimaal 12 uur per week of meer, de afgelopen 4 weken actief naar werk gezocht te hebben, en op korte termijn (binnen 2 weken) beschikbaar te zijn. 
Tabel 4.1

Huishoudsituatie van werklozen, 2001

\begin{tabular}{lrr}
\hline Kenmerk & $\%$ & $\%$ \\
\hline Partner & 85 & - \\
Geen thuiswonende kinderen & - & 47 \\
$\quad$ Eén thuiswonend kind & - & 15 \\
Minimaal twee thuiswonende kinderen & - & 100 \\
Totaal & - & - \\
Geen partner & 15 & - \\
Geen thuiswonende kinderen & - & 0 \\
Eén thuiswonend kind & - & 19 \\
Minimaal twee thuiswonende kinderen & - & 100 \\
Totaal & 100 & - \\
Totaal & - & 52 \\
Geen thuiswonende kinderen & - & 13 \\
Eén thuiswonend kind & - & 35 \\
Minimaal twee thuiswonende kinderen & - & 100 \\
Totaal & & \\
\hline
\end{tabular}

Bron: ROA

Tabel 4.2

Leeftijd jongste thuiswonende kind, werklozen met minimaal één kind, 2001

\begin{tabular}{lr}
\hline Leeftijd in jaren & $\%$ \\
\hline & \\
\hline-2 & \\
$5-9$ & 33 \\
$10-14$ & 4 \\
$15-19$ & 31 \\
$20-24$ & 6 \\
Totaal & 9 \\
& 18 \\
\hline
\end{tabular}

Bron: ROA

\section{Huidig inkomen}

Zoals verwacht mag worden verrichten werklozen over het algemeen geen betaald werk. Toch werkt 3 procent minder dan 12 uur per week, en 4 procent meer dan 12 uur per week. Niettemin zien zij zichzelf als werkloos omdat ze meer uren willen werken. Tabel 4.3 laat het maandelijkse netto persoonlijk en huishoudinkomen van werklozen zien. Ongeveer de helft heeft een netto inkomen van meer dan fl. 1.000 per maand, waaruit blijkt dat de werklozen een beduidend hoger persoonlijk inkomen hebben dan de niet-participerenden. Omdat de werklozen meestal geen betaald werk verrichten, is dit waarschijnlijk inkomen uit een (gedeeltelijke) werkloosheidsuitkering.

Wanneer het inkomen van een eventuele partner wordt meegenomen, dan vertonen de werklozen een maandelijks huishoudinkomen dat vergelijkbaar is met dat van de niet-participerenden. Onder de werklozen is wel een groter percentage met een huishoudinkomen tussen 1.000 en 2.000 gulden per maand, hetgeen gedeeltelijk 
terug te voeren is op het groter percentage alleenstaanden onder de werklozen ${ }^{10}$. Verder heeft meer dan 80 procent van de partners van de werkloze apothekersassistenten een voltijdbaan.

Tabel 4.3

Netto maandinkomen van werklozen, 2001

\begin{tabular}{lr} 
Netto maandinkomen & $\%$ \\
\hline Persoonlijk inkomen in guldens (euro's) & 40 \\
0 & 9 \\
$1-999(1-453)$ & 25 \\
$1000-1999(454-907)$ & 26 \\
$2000-2999$ (908-1361) & 0 \\
$3000-3999(1361-1815)$ & 0 \\
$4000-4999(1815-2268)$ & 0 \\
$5000-5999(2269-2722)$ & 0 \\
6000 of hoger (2723- ) & 100 \\
Totaal & \\
Huishoudinkomen in guldens (euro's) & 8 \\
0 & 0 \\
$1-999$ (1-453) & 14 \\
$1000-1999(454-907)$ & 5 \\
$2000-2999$ (908-1361) & 22 \\
$3000-3999$ (1361-1815) & 30 \\
$4000-4999$ (1815-2268) & 5 \\
$5000-5999$ (2269-2722) & 16 \\
6000 of hoger (2723- ) & 100 \\
Totaal & \\
\hline
\end{tabular}

Bron: ROA

\section{Arbeidsverleden}

Figuur 4.1 laat zien wat de laatste baan van de werklozen is geweest. Ongeveer 60 procent van de werklozen was als apothekersassistent werkzaam in hun laatste baan, 17 procent had een ander beroep in de gezondheidszorg en 24 procent had een beroep in een economisch-administratief of commercieel beroep. De werklozen hebben derhalve meer dan de niet-participerenden eerst nog elders gewerkt voordat men stopte met werken.

Niet alleen het type baan is van belang, maar ook wanneer men gestopt is met deze baan. Tabel 4.4 toont wanneer men voor het laatst betaald werk heeft verricht als apothekersassistent in de openbare apotheek. Ongeveer tweederde heeft nog als zodanig gewerkt vanaf 1995. Ongeveer eenderde heeft langer dan zes jaar geleden voor het laatst in een openbare apotheek gewerkt. Dit aandeel is beduidend kleiner dan onder de niet-participerenden. Werklozen zullen over het algemeen dus minder last hebben van de veroudering van kennis en vaardigheden die verband houden met het werk als apothekersassistent.

10. Ook hier geldt dat het percentage dat aangeeft geen inkomen te hebben, waarschijnlijk geen inkomensopgave heeft willen doen. 
Figuur 4.1

Laatste baan van werklozen, 2001

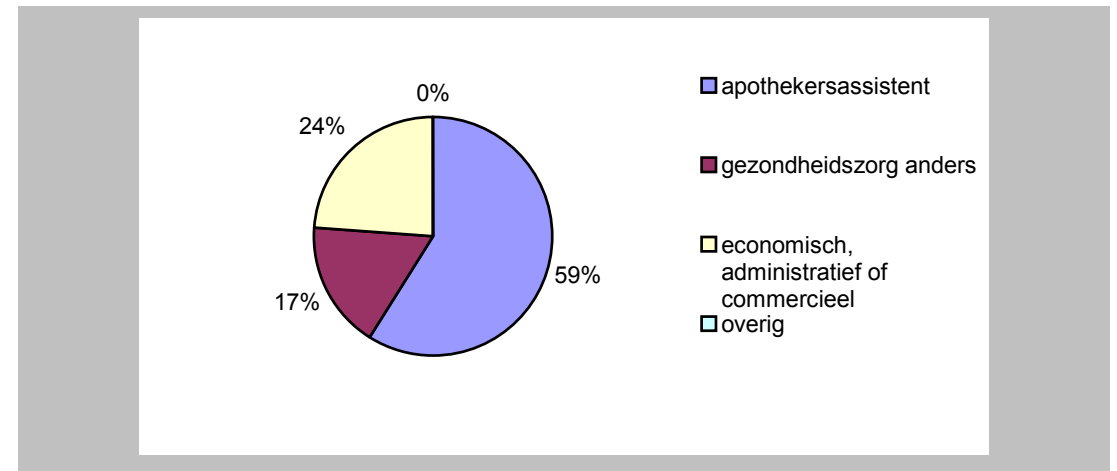

Bron: ROA

Tabel 4.4

Laatste arbeidsjaar als apothekersassistent in de openbare apotheek, werklozen, 2001

Laatste arbeidsjaar

1975-1979

1980-1984

$1985-1989$

1990-1994

1995-1999

2000

Totaal

Bron: ROA

Het derde aspect van het arbeidsverleden van de werkloze apothekersassistenten is het diplomajaar. Tabel 4.5 geeft voor de werklozen aan wanneer ze de opleiding tot apothekersassistent hebben afgerond. Dit diplomajaar is voor veel werklozen lang geleden. Ongeveer de helft van de werklozen heeft de opleiding tot apothekersassistent behaald vóór 1970. Onder de werklozen is zelfs niemand te vinden met een recenter diplomajaar dan 1994. Dit is aanzienlijk ongunstiger dan voor de nietparticiperenden, en houdt uiteraard verband met de hogere gemiddelde leeftijd van werklozen. Bijna de helft van de werklozen heeft echter nog een opleiding gevolgd na het diploma tot apothekersassistent, namelijk 46 procent tegenover 42 procent van de niet-participerenden. Vaker dan bij de niet-participerenden betrof het een opleiding op MBO-niveau en in de farmaceutische richting.

Als voor werkgevers het diplomajaar een rol speelt bij het aannemen van personeel, betekent dit dat de gemiddeld oudere werklozen wat dat betreft in het nadeel zijn ten opzichte van herintreders. Oudere werklozen kunnen echter wel meer werkervaring in de openbare apotheek hebben opgedaan. Tabel 4.6 laat zien dat de gemiddelde werkervaring van werklozen inderdaad hoger ligt dan bij de niet-participerenden. 
Bijna driekwart van de werklozen heeft meer dan 10 jaar werkervaring als apothekersassistent in een openbare apotheek, tegenover de helft van de nietparticiperenden.

Tabel 4.5

Diplomajaar van werklozen, 2001

\begin{tabular}{lr}
\hline Diplomajaar & $\%$ \\
\hline $1960-1964$ & 26 \\
$1965-1969$ & 23 \\
$1970-1974$ & 9 \\
$1975-1979$ & 17 \\
$1980-1984$ & 10 \\
$1985-1989$ & 11 \\
$1990-1994$ & 5 \\
Totaal & 100
\end{tabular}

Bron: ROA

Tabel 4.6

Werkervaring als apothekersassistent, werklozen, 2001

\begin{tabular}{lrr}
\hline Aantal jaren ervaring & $\%$ & $\begin{array}{r}\text { waarvan } \\
50 \text { jaar of ouder } \\
\%\end{array}$ \\
\hline $0-5$ & & 0 \\
$6-10$ & 18 & 22 \\
$11-15$ & 25 & 36 \\
$16-20$ & 25 & 60 \\
$20-25$ & 11 & 50 \\
$26-30$ & 5 & 100 \\
meer dan 30 & 7 & 51 \\
Totaal & 100 & \\
\hline Bron: ROA & & \\
\hline
\end{tabular}

\section{Redenen van uittrede}

Een belangrijke vraag, ook voor de werklozen, is waarom men ooit is uitgetreden. Tabel 4.7 toont voor de werklozen de voornaamste redenen om te stoppen met het werk als apothekersassistent in de openbare apotheek. De redenen van uittrede zijn duidelijk anders dan bij de niet-participerenden. De zorg voor het huishouden en kinderen was voor de werklozen een veel minder belangrijke reden van uittrede. Slechts 15 procent geeft dit als primaire reden voor de uittrede, terwijl de helft van de niet-participerenden dit als belangrijkste reden voor uittrede noemde. Deze groep is oorspronkelijk gestopt met het werk in de openbare apotheek vanwege de huishoudelijke of zorgtaken, maar wil waarschijnlijk inmiddels weer gaan werken. De grootste groep van werkloze apothekersassistenten is echter onvrijwillig werkloos geworden door bijvoorbeeld de afloop van het contract of ontslag. Dit biedt eveneens een verklaring voor het relatief hoge percentage werklozen dat een werkloosheid- 
uitkering ontvangt. Verder is een relatief grote groep van werklozen om gezondheidsredenen gestopt met werken in de openbare apotheek.

Tabel 4.7

Reden van uittrede als apothekersassistent uit de openbare apotheek, werklozen, 2001

\begin{tabular}{ll}
\hline Reden & $\%$
\end{tabular}

Zorg voor de kinderen, huishoudelijk werk of andere zorgtaken

Te weinig faciliteiten voor kinderopvang of buitenschoolse opvang

Studie

Gezondheid

Reistijd naar het werk was te groot

Werk was niet leuk genoeg

Hoge werkdruk

Werk bood te weinig carrièreperspectief

Werk was financieel niet aantrekkelijk genoeg

Te weinig mogelijkheden voor deeltijdwerk

Te weinig mogelijkheden voor flexibele werktijden

Onregelmatige diensten

Onvrijwillig werkloos geworden

Overig

Totaal

Bron: ROA

Bereidheid tot werken in de openbare apotheek

Figuur 4.2 toont de bereidheid van werklozen om weer aan de slag te gaan als apothekersassistent in de openbare apotheek. Ruim eenderde wijst het aanvaarden van werk als apothekersassistenten in een openbare apotheek af. Verder wil 13 procent zonder voorwaarden werk aanvaarden, en 50 procent verbindt hieraan bepaalde voorwaarden.

Figuur 4.2

Bereidheid van werklozen om te werken als apothekersassistent in de openbare apotheek, 2001

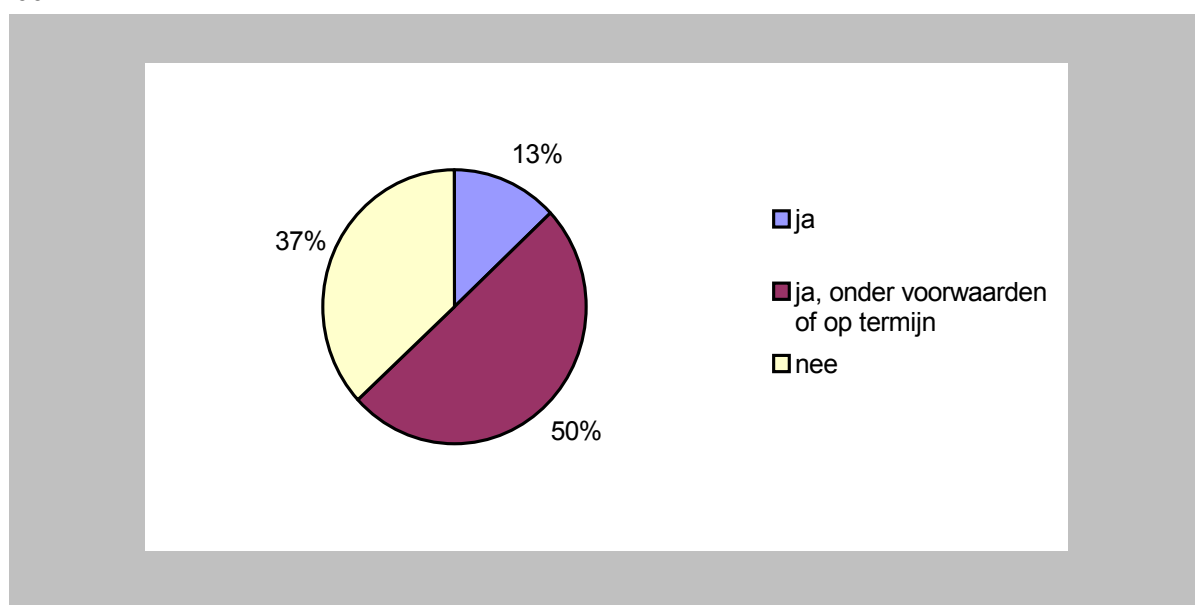

Bron: ROA 
Het totaalpercentage van werklozen dat niet in de openbare apotheek wil gaan werken is 37 procent, en ligt daarmee 7 procent lager uit dan bij de niet-participerenden. Evenals de niet-participerenden zegt ongeveer de helft van de werklozen wel te willen terugkeren, maar enkel onder bepaalde voorwaarden of op termijn.

Hieronder zal nader ingegaan worden op de verschillen tussen de werklozen en de niet-participerenden wat betreft hun bereidheid om terug te keren naar de openbare apotheek ${ }^{11}$. Tabel 4.8 geeft verschillende belemmeringen weer die werklozen en nietparticiperenden kunnen ervaren bij de terugkeer naar de openbare apotheek. Zoals door de huishoudsamenstelling verwacht mocht worden, worden werklozen veel minder dan niet-participerenden belemmerd door zorgtaken en huishoudelijk werk, en door faciliteiten voor kinderopvang en buitenschoolse opvang. Andere belangrijke verschillen in belemmeringen tussen werklozen en niet-participerenden zijn de hoge werkdruk die de werklozen ervaren, eventueel in combinatie met een slechtere gezondheid, en het ontbreken van geschikt werk voor werklozen om als apothekersassistent in een openbare apotheek te gaan werken.

Tabel 4.8

Belemmeringen bij de terugkeer als apothekersassistent (AA) in de openbare apotheek (OA), van niet-participerenden en werklozen, 2001

Belemmering niet-participerend werkloos

$\begin{array}{rr}\text { niet-participerend } & \text { werkloos } \\ \% & \%\end{array}$

Zorg voor kinderen, huishoudelijk werk of andere zorgtaken

Geen behoefte aan betaald werk

Studie

Kennis en vaardigheden aanzienlijk afgenomen

Gezondheid

Financieel onaantrekkelijk

Reistijd naar het werk

Te weinig deeltijdmogelijkheden

Te weinig flexibele werktijden

Te weinig faciliteiten voor kinderopvang

of buitenschoolse opvang

Te veel onregelmatige diensten

Hoge werkdruk

Werk als AA minder leuk dan ander werk

Werk in OA minder leuk dan elders

Te weinig carrièreperspectief

Geen geschikt werk (als AA in OA) gevonden

Bron: ROA

Verder zijn te geringe deeltijdmogelijkheden en te veel onregelmatige diensten een belangrijkere belemmering voor werklozen dan voor niet-participerenden. Werklozen hechten daarentegen minder waarde aan de mogelijkheden voor flexibele werktijden.

11. In tegenstelling tot de analyse bij de niet-participerenden zal bij de werklozen minder de nadruk liggen op het verschil tussen degenen die absoluut of voorwaardelijk bereid zijn terug te keren naar de openbare apotheek. De reden hiervoor is dat het de groep werklozen vrij klein is (44 respondenten), waardoor een vergaande uitsplitsing niet erg betrouwbaar is. Bovendien wordt een vergelijking met de niet-participerenden veel gecompliceerder als beide groepen nog eens worden uitgesplitst. 
Verder lijken de werklozen meer moeite te hebben met de reistijd naar het werk ${ }^{12}$, en vinden zij het werken als apothekersassistent in de openbare apotheek minder leuk dan niet-participerenden.

Tabel 4.9 geeft aan hoeveel uur per week de werklozen die bereid zijn terug te keren naar de openbare apotheek zouden willen werken. De verdeling van het gewenste aantal uren per week van de werklozen komt redelijk goed overeen met de verdeling van de niet-participerenden. Er lijken relatief iets meer werklozen dan niet-participerenden te zijn die minder dan 8 uur of meer dan 32 uur willen werken. Van belang is dat zowel bij de werklozen als bij de potentiële herintreders maar ongeveer een kwart meer dan 2 dagen per week wil werken.

Tabel 4.9

Gewenste aantal uren betaald werk per week van de niet-participerenden en werklozen die bereid zijn terug te keren naar de openbare apotheek, 2001

\begin{tabular}{lrr}
\hline Gewenst aantal uren per week & $\begin{array}{r}\text { niet-participerend } \\
\%\end{array}$ & $\begin{array}{r}\text { werkloos } \\
\%\end{array}$ \\
\hline $1-8$ & 6 & 11 \\
$9-16$ & 68 & 61 \\
$17-24$ & 21 & 21 \\
$25-32$ & 2 & 2 \\
meer dan 32 & 2 & 5 \\
Totaal & 100 & 100 \\
\hline
\end{tabular}

Bron: ROA

Het gewenste loon waartegen men bereid is weer te gaan werken, is een tweede mogelijke voorwaarde. Tabel 4.10 geeft het gewenste netto uurloon aan van de werklozen ten opzichte van de niet-participerenden. Het gewenste uurloon van de werklozen heeft een meer gespreide verdeling dan bij de niet-participerenden. Zo wil bijna een vijfde van de werklozen voor minder dan 16 gulden per uur aan de slag gaan. Aan de andere wil bijna een derde van de werklozen voor niet minder dan 26 gulden per uur werken. In het vorige hoofdstuk werd duidelijk dat een uurloon van ongeveer 20 gulden reëel lijkt te zijn op basis van de CAO-lonen. Apothekersassistenten die meer dan ongeveer 25 gulden per uur willen verdienen lijken dan ook over bijzondere kwaliteiten te moeten beschikken. Aangezien meer dan de helft van de werklozen 50 jaar of ouder is, kan het natuurlijk zijn dat zij hun jarenlange ervaring gehonoreerd willen zien. Daarnaast is het ook mogelijk dat de werklozen met een relatief hoge werkloosheidsuitkering het niet financieel aantrekkelijk genoeg vinden om tegen een netto loon van ongeveer 20 gulden per uur aan de slag te gaan.

12. Hieronder zal echter blijken dat dit genuanceerder ligt. 
Tabel 4.10

Gewenst netto uurloon, niet-participerenden en werklozen, 2001

\begin{tabular}{lrr}
\hline Gewenst netto uurloon in guldens (euro's) & niet-participerend & werkloos \\
\hline minder dan $10(-4,54)$ & 1 & 0 \\
$11-15(4,99-6,81)$ & 9 & 18 \\
$16-20(7,26-9,08)$ & 43 & 29 \\
$21-25(9,53-11,34)$ & 35 & 22 \\
$26-30(11,80-13,61)$ & 9 & 24 \\
meer dan 30 (13,61-) & 4 & 7 \\
Totaal & 100 & 100 \\
\hline
\end{tabular}

Bron: ROA

In tabel 4.11 wordt een aantal andere indicatoren weergegeven die de bereidheid van werklozen ten opzichte van niet-participerenden weerspiegelen. Uit de tabel wordt duidelijk dat werklozen veel vaker dan niet-participerenden zoeken naar werk en ingeschreven staan bij het arbeidsbureau. Bij nadere analyse van de inschrijvingsduur blijkt dat eenderde van de werklozen minder dan 1 jaar staat ingeschreven bij het arbeidsbureau. Verder is ook driekwart van de werklozen binnen vier weken beschikbaar voor een nieuwe functie, terwijl dat slechts voor een derde van de niet-participerenden geldt. Bovendien zijn de werklozen meer dan de nietparticiperenden bereid om te reizen. Dit staat echter in contrast met de bevinding in tabel 4.8 dat de reistijd naar het werk door meer werklozen dan door nietparticiperenden als een belemmering voor de terugkeer naar de openbare apotheek wordt ervaren. Een verklaring hiervoor zou kunnen zijn dat werklozen het vanzelfsprekender vinden om grotere afstanden naar het werk te moeten reizen, maar dit tegelijkertijd eerder als een belemmering ervaren.

Tabel 4.11

Bereidheid van werklozen ten opzichte van niet-participerenden bij de terugkeer naar de openbare apotheek, 2001

\begin{tabular}{lcc}
\hline & niet-participerend & $\begin{array}{c}\text { werkloos } \\
\%\end{array}$ \\
& & \\
\hline & 13 & 49 \\
Laatste drie maanden ander werk gezocht & 4 & 35 \\
Ingeschreven bij het arbeidsbureau & 33 & 75 \\
Beschikbaar binnen vier weken & 40 & 67 \\
\hline
\end{tabular}

Bron: ROA

Over het algemeen blijkt dat werklozen meer dan de niet-participerenden bereid zijn om weer aan de slag te gaan, en daartoe ook iets ondernemen. De werklozen hoeven veel minder dan de potentiële herintreders rekening te houden met de gezinssituatie. Onder werklozen zijn veel meer vijftigplussers. Verder hebben zij een hoger persoonlijk inkomen, waarschijnlijk voor een belangrijk deel uit een werkloosheidsuitkering. Zowel de hogere leeftijd als de werkloosheidsuitkering hebben mogelijk als consequentie dat de werklozen relatief hoge uurlonen vragen. Zij zijn 
duidelijk actiever op zoek naar een baan, en staan ook vaker ingeschreven bij het arbeidsbureau. Ze zijn tevens vaker op korte termijn inzetbaar in het arbeidsproces. Werkgevers moeten er echter wel rekening mee houden dat ongeveer driekwart van de werklozen een baan zoekt van niet meer dan twee dagen per week. 


\section{De werkenden buiten de openbare apotheek}

De derde groep van het onbenutte arbeidspotentieel zijn de gediplomeerde apothekersassistenten die thans buiten de openbare apotheek werken. Evenals de nietparticiperenden en de werklozen hebben ook zij ooit ervaring opgedaan als apothekersassistent in de openbare apotheek. In hoofdstuk 2 is al aangegeven dat ongeveer 1.000 gediplomeerde apothekersassistenten buiten de openbare apotheek als apothekersassistent werken, terwijl ongeveer 6.000 gediplomeerde apothekersassistenten een ander beroep binnen of buiten de gezondheidszorg hebben. Onder de werkenden van het onbenutte arbeidspotentieel voor de openbare apotheek is ongeveer 4 procent man. Dit is beduidend meer dan onder de niet-participerenden en de werklozen, waar slechts ongeveer 1 procent vrouw is. Voorts zijn er onder de werkenden meer jongeren tot 30 jaar, en minder vijftigplussers, dan onder de nietparticiperenden en werklozen.

Van de werkenden mag worden verwacht dat zijn in principe goed in staat zijn om in de openbare apotheek te werken. Zij zullen in beduidend mindere mate dan de potentiële herintreders worden belemmerd door de huishoudsituatie. Derhalve is het bij deze groep met name interessant om te kijken naar wat hen ertoe heeft gebracht om een andere baan buiten de openbare apotheek te aanvaarden. Verder is ook het beeld dat zij hebben van het werken in de openbare apotheek interessant, omdat zij immers hun voormalige werk goed kunnen vergelijken met hun huidige werk.

\section{Huishoudsituatie}

De huishoudsituatie verschilt niet erg veel tussen de werkenden en de werklozen. Ongeveer 80 procent van de werkenden heeft een partner, hetgeen ongeveer

Tabel 5.1

Huishoudsituatie van werkenden, 2001

\begin{tabular}{lrr}
\hline Kenmerk & $\%$ & $\%$ \\
\hline Partner & & \\
$\quad$ Geen thuiswonende kinderen & 82 & - \\
1 thuiswonend kind & - & 34 \\
Minimaal 2 thuiswonende kinderen & - & 18 \\
Totaal & - & 48 \\
Geen partner & - & -100 \\
Geen thuiswonende kinderen & 18 & - \\
1 thuiswonend kind & - & 95 \\
Minimaal 2 thuiswonende kinderen & - & 16 \\
Totaal & - & 100 \\
Totaal & & - \\
Geen thuiswonende kinderen & 100 & - \\
1 thuiswonend kind & - & 16 \\
Minimaal 2 thuiswonende kinderen & - & 43 \\
Totaal & - & 100 \\
\hline
\end{tabular}

Bron: ROA 
hetzelfde als bij de werklozen maar lager dan bij de niet-participerenden. De werkenden hebben wel iets vaker dan de werklozen thuiswonende kinderen. Bijna 90 procent van de partners van de werkenden heeft een betaalde baan. Veruit de meeste apothekersassistenten die buiten de openbare apotheek werken zijn dus tweeverdieners.

\section{Huidige baan en arbeidsverleden}

Om zicht te krijgen op de arbeidssituatie van de werkenden buiten de openbare apotheek is het van belang om na te gaan waar zij thans werkzaam zijn. Uit hoofdstuk 2 bleek dat ongeveer 1.000 van de 7.000 werkenden buiten de openbare apotheek als apothekersassistent werkzaam zijn, bijvoorbeeld in een ziekenhuisapotheek. Dit is ongeveer 14 procent. Uit de figuur 5.1 blijkt echter dat 32 procent van de werkenden buiten de openbare apotheek werkzaam is als apothekersassistent. Het gaat bij dit percentage om de groep van werkenden die voorheen als apothekersassistent in de openbare apotheek werkte ${ }^{13}$. Deze groep maakt gemakkelijker een overstap naar het beroep van apothekersassistent buiten de openbare apotheek dan de groep die nooit als apothekersassistent in de openbare apotheek heeft gewerkt. Het verschil tussen de beide percentages ontstaat doordat apothekersassistenten vaak eerst in de openbare apotheek hebben gewerkt voordat ze buiten de openbare apotheek aan de slag gaan als apothekersassistent ${ }^{14}$.

Verder blijkt uit figuur 5.1 dat 15 procent van de gediplomeerde apothekersassistenten met ervaring in de openbare apotheek elders in de gezondheidszorg werkt. In totaal komt dus bijna de helft van deze groep in de gezondheidszorg terecht als ze openbare apotheek verlaten.

Figuur 5.1

Huidige baan van de werkenden, 2001

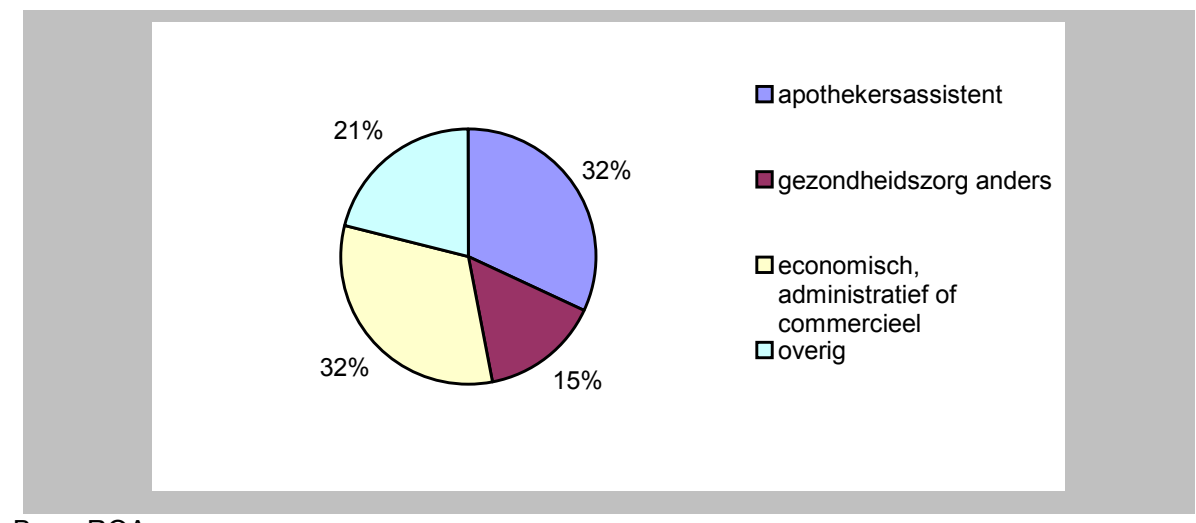

Bron: ROA

13. Deze mensen hebben zich bovendien niet laten uitschrijven uit het pensioenbestand van de PMA (zie bijlage A).

14. Zoals in hoofdstuk 1 is aangegeven, heeft de steekproef van niet-participerenden, werklozen en werkenden alleen betrekking op gediplomeerde apothekersassistenten die ooit in de openbare apotheek hebben gewerkt. 
Als het gaat om het maken van een inschatting van de inzetbaarheid van deze aanbodgroep binnen de openbare apotheek, dan ligt de conclusie voor de hand: ongeveer eenderde van de groep is thans werkzaam in een vergelijkbare situatie, en daarmee bij uitstek geschikt voor herintrede.

Tabel 5.2 geeft aan hoeveel jaar werkervaring als apothekersassistent de werkenden buiten de openbare apotheek hebben. Zoals verwacht mag worden hebben de werkenden die nog steeds als apothekersassistent werken, gemiddeld genomen de meeste ervaring. Voor de werkenden die niet meer als apothekersassistent werken, heeft nog altijd ongeveer 45 procent meer dan 10 jaar ervaring als apothekersassistent.

Tabel 5.2

Ervaring als apothekersassistent naar huidige baan van werkenden, 2001

\begin{tabular}{|c|c|c|c|c|}
\hline $\begin{array}{l}\text { Aantal jaren } \\
\text { ervaring }\end{array}$ & $\begin{array}{r}\text { apothekersassistent } \\
\text { buiten de openbare } \\
\text { apotheek } \\
\%\end{array}$ & $\begin{array}{r}\text { Huidige baan } \\
\text { gezondheids- } \\
\text { zorg } \\
\text { anders } \\
\%\end{array}$ & $\begin{array}{r}\text { economisch- } \\
\text { administratief, } \\
\text { commercieel } \\
\%\end{array}$ & $\begin{array}{r}\text { overig } \\
\\
\%\end{array}$ \\
\hline $\begin{array}{l}0-5 \\
6-10 \\
11-15 \\
16-20 \\
20-25 \\
26-30 \\
\text { meer dan } 30\end{array}$ & $\begin{array}{r}14 \\
23 \\
22 \\
19 \\
12 \\
8 \\
2\end{array}$ & $\begin{array}{r}15 \\
41 \\
27 \\
14 \\
1 \\
2 \\
0\end{array}$ & $\begin{array}{r}20 \\
35 \\
28 \\
9 \\
5 \\
1 \\
2\end{array}$ & $\begin{array}{r}19 \\
35 \\
30 \\
13 \\
2 \\
0 \\
1\end{array}$ \\
\hline Totaal & 100 & 100 & 100 & 100 \\
\hline
\end{tabular}

Bron: ROA

Voor de veroudering van kennis en vaardigheden is het van belang te weten hoe lang geleden men de openbare apotheek heeft verlaten. Tabel 5.3 presenteert, wederom uitgesplitst naar de huidige baan, het jaar waarin men voor het laatst als apothekersassistent in de openbare apotheek werkzaam was. Met name de werkende apothekersassistenten en degenen die werkzaam zijn in een economischadministratieve of commerciële functie, geven aan de overstap uit de openbare apotheek pas recent, in de laatste twee jaar, te hebben gemaakt. Ongeveer 30 procent van hen werkte in 1999 of 2000 voor het laatst als apothekersassistent in de openbare apotheek. Voor de twee andere baancategorieën - gezondheidszorg elders en overig - geldt dat ongeveer 50 procent de afgelopen vijf jaar nog als apothekersassistent in de openbare apotheek werkzaam is geweest ${ }^{15}$.

15. Men dient vooral bij het aantal jaren werkervaring als apothekersassistent rekening te houden met de selectiviteit van de steekproef (zie hoofdstuk 1 en bijlage A). In dit hoofdstuk gaat het uitsluitend om de werkenden die ooit in de openbare apotheek hebben gewerkt. 
Zoals reeds opgemerkt zijn de werkenden buiten de openbare apotheek ten opzichte van de niet-participerenden en de werklozen van jonge leeftijd. Daarmee hangt samen dat zij relatief vaak hun diploma voor apothekersassistent in het jaar 1990 of in een later jaar hebben behaald. Dit geldt vooral voor degenen die als apothekersassistent werken: 27 procent heeft vanaf 1990 het diploma voor apothekersassistent behaald, tegenover 21 procent van degenen die in een ander beroep werken. Beide groepen werkenden hebben bovendien vaker dan de niet-participerenden en de werklozen een vervolgopleiding gedaan, namelijk 51 procent van de werkenden als apothekersassistent en 61 procent van de werkenden in een ander beroep. Voor de werkende apothekersassistenten was dat veelal een farmaceutische opleiding op MBO-niveau, voor de werkenden in een ander beroep was dat ook vaak een opleiding op HBO-niveau in een andere richting.

Tabel 5.3

Laatste arbeidsjaar als apothekersassistent in de openbare apotheek naar huidige baan van werkenden, 2001

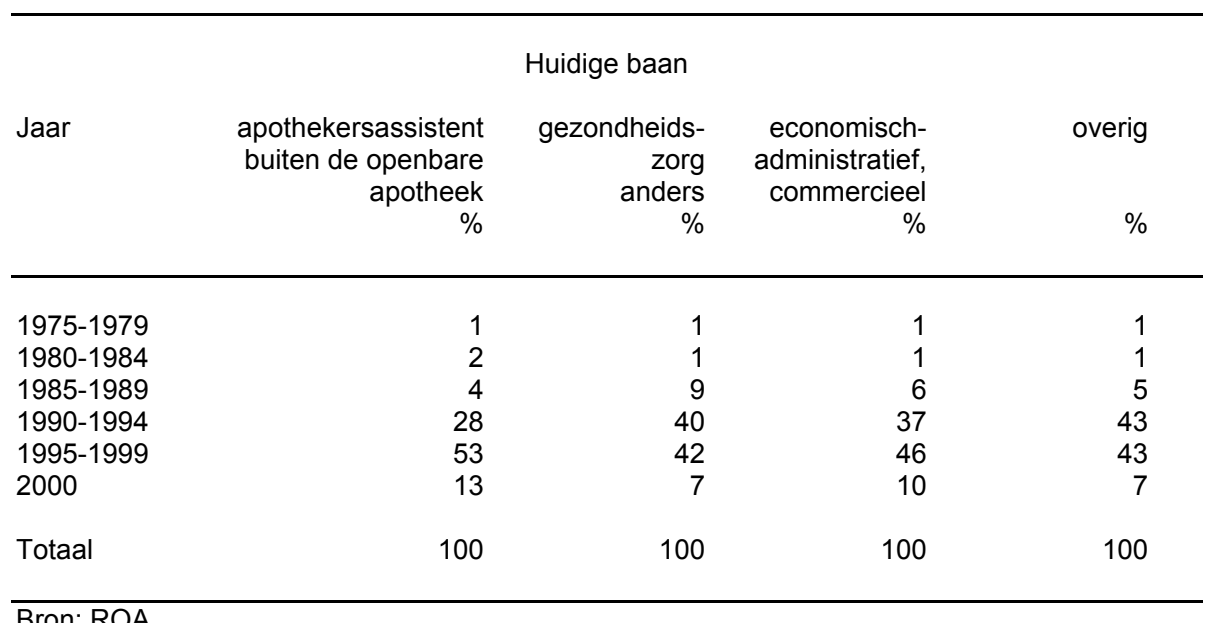

Bron: ROA

Uit het bovenstaande valt op dat de werkenden zeer aantrekkelijke kenmerken hebben voor werkgevers van de openbare apotheek, want ze hebben veel werkervaring in de openbare apotheek, die in veel gevallen redelijk recent is. Bovendien is het relatief kort geleden dat ze hun opleiding tot apothekersassistent hebben afgerond, en laten ze wat meer ambitie zien bij de deelname aan vervolgopleidingen.

\section{Redenen van uittrede}

De werkenden buiten de openbare apotheek vormen een aantrekkelijke groep van het onbenutte arbeidspotentieel vanwege de beschikbaarheid om te werken, de relevante werkervaring en de relatief recente investeringen in hun opleidingen. Het is derhalve van belang om te weten waarom ze een baan buiten de openbare apotheek hebben aanvaard. De belangrijkste reden voor uittrede voor de werkenden was, 
evenals bij de niet-participerenden en de werklozen, huishoudelijk werk en zorgtaken. Het percentage ligt bij de werkenden echter beduidend lager. Andere belangrijke redenen voor het vertrek uit de openbare apotheek waren dat men het werk niet leuk genoeg vond en dat er te weinig carrièremogelijkheden waren.

Tabel 5.4

Redenen van uittrede als apothekersassistent in de openbare apotheek, werkenden, 2001

\begin{tabular}{lrr}
\hline Reden & $\begin{array}{r}\text { werkend } \\
\text { als AA } \\
\%\end{array}$ & $\begin{array}{r}\text { werkend } \\
\text { anders } \\
\%\end{array}$ \\
\hline & 17 & 18 \\
Zorg voor kinderen, huishoudelijk werk of andere zorgtaken & 0 & 1 \\
Te weinig faciliteiten voor kinderopvang of buitenschoolse opvang & 0 & 1 \\
Studie & 14 & 12 \\
Werk was niet leuk genoeg & 10 & 17 \\
Werk bood te weinig carrièreperspectief & 5 & 8 \\
Werk was financieel niet aantrekkelijk genoeg & 4 & 0 \\
Reistijd naar het werk was te groot & 9 & 7 \\
Te weinig mogelijkheden voor deeltijdwerk & 1 & 3 \\
Te weinig mogelijkheden voor flexibele werktijden & 3 & 2 \\
Onregelmatige diensten & 10 & 4 \\
Hoge werkdruk & 4 & 5 \\
Onvrijwillig werkloos geworden & 1 & 4 \\
Gezondheid & 24 & 17 \\
Overig & 100 & 100 \\
Totaal & & \\
& & \\
\hline
\end{tabular}

Bron: ROA

Figuur 5.2

Bereidheid van werkenden om terug te keren naar de openbare apotheek, 2001

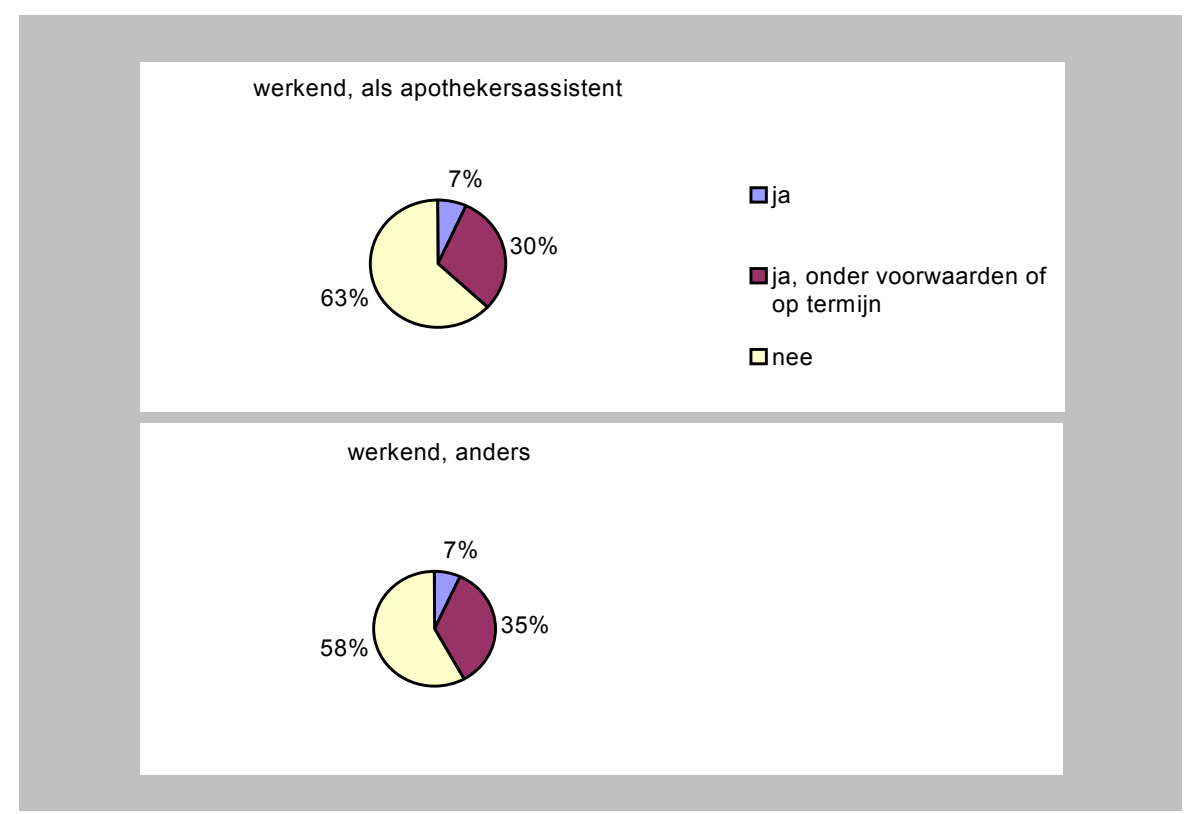

Bron: ROA 


\section{Bereidheid tot terugkeer naar de openbare apotheek}

De bereidheid van werkenden om weer terug te keren naar de openbare apotheek geeft aan hoeveel potentieel aanbod er onder hen is. Ongeveer 40 procent van de werkenden is inderdaad bereid om weer in de openbare apotheek te gaan werken. Dit percentage ligt iets hoger voor de werkenden in een ander beroep dan apothekersassistent. De vraag is nu wat de werkenden buiten de openbare apotheek ervan weerhoudt om weer terug te keren. In tabel 5.5 wordt een beeld gegeven van de belemmeringen die de werkenden ervaren bij de terugkeer naar de openbare apotheek. De financiële onaantrekkelijkheid en het gebrek aan carrièreperspectief worden het meest genoemd als belemmering bij een eventuele terugkeer. Zoals verwacht mag worden lijken degenen die als apothekersassistent buiten de openbare apotheek werken het werk als apothekersassistent leuk te vinden, maar het werken in de openbare apotheek beduidend minder aantrekkelijk. Overigens heeft meer dan 90 procent van beide groepen het werk als apothekersassistent met plezier gedaan ${ }^{16}$. Het omgekeerde geldt voor de werkenden die niet in het beroep van apothekersassistenten werken: voor hen is het werken in de openbare apotheek geen grote belemmering, maar wel het werk als apothekersassistent.

Tabel 5.5

Belemmeringen bij de terugkeer als apothekersassistent (AA) in de openbare apotheek (OA) van werkenden, 2001

\begin{tabular}{lrr}
\hline Belemmering & $\begin{array}{r}\text { werkend } \\
\text { als AA } \\
\%\end{array}$ & $\begin{array}{r}\text { werkend } \\
\text { anders } \\
\%\end{array}$ \\
& & \\
\hline Zorg voor kinderen, huishoudelijk & 20 & 22 \\
$\quad$ werk of andere zorgtaken & 0 & 1 \\
Geen behoefte aan betaald werk & 1 & 1 \\
Studie & 7 & 18 \\
Kennis en vaardigheden aanzienlijk afgenomen & 3 & 6 \\
Gezondheid & 30 & 35 \\
Financieel onaantrekkelijk & 8 & 4 \\
Reistijd naar het werk & 12 & 13 \\
Te weinig deeltijdmogelijkheden & 20 & 24 \\
Te weinig flexibele werktijden & 10 & 8 \\
$\quad$ of buitenschoolse opvang & 24 & 24 \\
Te veel onregelmatige diensten & 29 & 22 \\
Hoge werkdruk & 8 & 25 \\
Werk als AA minder leuk dan ander werk & 37 & 12 \\
Werk in OA minder leuk dan elders & 29 & 32 \\
Te weinig carrièreperspectief & 4 & 5 \\
Geen geschikt werk (als AA in OA) gevonden & & \\
\hline Bron: ROA & &
\end{tabular}

Bron: ROA

16. In dit hoofdstuk zal, evenals in het vorige hoofdstuk, niet verder worden ingegaan op het imago van de beroepsgroep en de opleiding. Dit is reeds behandeld in hoofdstuk 3 voor de niet-participerenden. De verschillen met de werklozen en de werkenden zijn over het algemeen te klein of te voor de hand liggend om nog eens apart te bespreken, en komen voor zover van belang al elders in hoofdstuk 4 en 5 aan de orde. Zie voorts de tabellen 15 en 16 van bijlage $C$. 
Verder zijn een te hoge werkdruk, te veel onregelmatige diensten en te weinig flexibele werktijden belangrijke belemmeringen die een eventuele terugkeer naar de openbare apotheek in de weg kunnen staan. Toch zijn de flexibele werktijden, maar ook de huishoudelijke en zorgtaken en de deeltijdmogelijkheden van veel minder groot belang voor de werkenden dan voor de niet-participerenden als belemmering bij een eventuele terugkeer.

Uit de voorgaande twee hoofdstukken is gebleken dat het grootste deel van de potentiële herintreders en de werklozen hooguit twee dagen per week wil werken in de openbare apotheek. Mede gezien het minder grote belang dat de werkenden hechten aan de deeltijdmogelijkheden, zal het aantal dagen per week van degenen die bereid zijn terug te keren naar de openbare apotheek naar verwachting groter zijn dan voor de potentiële herintreders en de werklozen. In tabel 5.6 is het aantal uren per week dat de werkenden in de openbare apotheek aan betaald werk willen verrichten, afgezet tegen het huidige aantal uren betaald werk buiten de openbare apotheek. Verder zijn de werkenden onderverdeeld in degenen die als apothekersassistent werken en degenen die een ander beroep uitoefenen.

Tabel 5.6

Gewenste en werkelijke aantal uren betaald werk per week, werkenden, 2001

\begin{tabular}{|c|c|c|c|c|}
\hline \multirow[t]{2}{*}{ Aantal uren per week } & \multicolumn{2}{|c|}{ werkend als AA } & \multicolumn{2}{|c|}{ werkend anders } \\
\hline & $\begin{array}{r}\text { gewenst } \\
\text { in OA } \\
\%\end{array}$ & $\begin{array}{r}\text { werkelijk } \\
\text { buiten OA } \\
\%\end{array}$ & $\begin{array}{r}\text { gewenst } \\
\text { in OA } \\
\%\end{array}$ & $\begin{array}{r}\text { werkelijk } \\
\text { buiten OA } \\
\%\end{array}$ \\
\hline $1-8$ & 4 & 5 & 3 & 8 \\
\hline $9-16$ & 34 & 27 & 32 & 21 \\
\hline $17-24$ & 35 & 27 & 37 & 25 \\
\hline $25-32$ & 10 & 20 & 12 & 14 \\
\hline meer dan 32 & 18 & 22 & 17 & 32 \\
\hline Totaal & 100 & 100 & 100 & 100 \\
\hline
\end{tabular}

Bron: ROA

Het blijkt dat ongeveer eenderde maximaal twee dagen per week wil werken. Bijna tweederde wil meer dan 2 dagen per week werken. Met name dit laatste percentage ligt beduidend hoger dan bij de potentiële herintreders en de werklozen, voor wie dat slechts voor ongeveer een kwart geldt. Toch valt het gewenste aantal uren van de werkenden die bereid zijn terug te keren naar de openbare apotheek enigzins tegen ten opzichte van het aantal uren dat ze werken in hun huidige baan. Een verklaring hiervoor kan zijn dat men de overstap naar de openbare apotheek alleen aantrekkelijk vindt als er minder uren gewerkt hoeven te worden. Uit tabel $5.7 \mathrm{blijkt}$ dat men bij een overstap naar de openbare apotheek niet alleen minder uren wil gaan werken, maar ook meer per uur wil gaan verdienen. Het percentage werkenden dat bereid is terug te keren voor netto 20 gulden per uur of minder is aanzienlijk kleiner ten opzichte van de huidige situatie wat betreft de uurlonen, terwijl het percentage dat meer dan netto 20 gulden per uur wil gaan verdienen in de openbare apotheek veel groter is dan het percentage dat in de huidige baan meer dan 20 gulden per uur verdient. Het hogere gewenste netto uurloon houdt waarschijnlijk 
verband met een (gedeeltelijke) compensatie van het lagere inkomen dat ontstaat door het lagere aantal uren dat men wenst te werken bij een terugkeer naar de openbare apotheek.

Tabel 5.7

Gewenste netto uurloon in de openbare apotheek (OA) en werkelijke netto uurloon buiten de openbare apotheek van werkenden die bereid zijn terug te keren, 2001

Netto uurloon

werkend als AA

in guldens (euro's)

$\begin{array}{rr}\text { gewenst } & \text { werkelijk } \\ \text { in OA } & \text { buiten OA } \\ \% & \%\end{array}$

werkend anders

gewenst werkelijk

in $\mathrm{OA}$ buiten $\mathrm{OA}$

$\% \quad \%$

minder dan $10(-4,54)$

$11-15(4,99-6,81)$

$16-20(7,26-9,08)$

21-25 (9,53-11,34)

26-30 (11,80-13,61)

meer dan $30(13,61-)$

$0 \quad 0$

0

$\begin{array}{ll}0 & 1\end{array}$

Totaal

$3-13$

Bron: ROA 


\section{Conclusie: de weg terug naar de openbare apotheek}

Het onbenutte arbeidspotentieel van apothekersassistenten is een aanzienlijke arbeidsreserve die bij grote krapte op de arbeidsmarkt goed kan worden ingezet om de knelpunten in de personeelsvoorziening van de openbare apotheek te verlichten. Traditioneel zijn de apothekersassistenten vrijwel allemaal vrouwen, die zich bij het krijgen van kinderen vaak voor korte of lange tijd terugtrekken van de arbeidsmarkt. Het is derhalve van groot belang dat de openbare apotheek voldoende in beeld is bij een eventuele herintrede van deze uitgetreden apothekersassistenten. Naast deze potentiële herintreders is er ook een klein aantal werklozen met een diploma tot apothekersassistent. Tot slot is er een derde groep van gediplomeerde apothekersassistenten die buiten de openbare apotheek werkt, en ook in staat is om een baan in de openbare apotheek te aanvaarden. Een deel van deze groep werkt nog steeds als apothekersassistent.

Uit het bovenstaande blijkt dat de samenstelling van het onbenutte arbeidspotentieel erg heterogeen is. Bovendien blijkt dat uit de voorgaande hoofdstukken dat er grote verschillen tussen de bovengenoemde groepen kunnen zijn qua leeftijdsopbouw, huishoudsituatie, de bereidheid om terug te keren naar de openbare apotheek en de belemmeringen die hierbij ervaren worden. Bij een wervings- of imagocampagne voor de openbare apotheek of voor het vak van apothekersassistent dient rekening gehouden te worden met de verschillen in achtergrondkenmerken tussen de verschillende groepen van het onbenutte arbeidspotentieel en hun bereidheid en motivatie om weer in de openbare apotheek aan de slag te gaan. Het totale onbenutte arbeidspotentieel voor de openbare apotheek is 56 procent van de 29.000 gediplomeerde apothekersassistenten in Nederland. De verschillen tussen de zes regio's van Nederland zijn klein wat betreft dit percentage en de onderverdeling in de bovengenoemde groepen per regio. De achtergrondkenmerken en de bereidheid om terug te keren naar de openbare apotheek kunnen dan ook beter aan de hand van de onderverdeling in de verschillende heterogene groepen onderzocht worden, dan aan de hand van de verschillende regio's. In dit rapport zijn derhalve afzonderlijke hoofdstukken gewijd aan respectievelijk de niet-participerenden (hoofdstuk 3), de werklozen (hoofdstuk 4) en de werkenden in het beroep van apothekersassistent buiten de openbare apotheek of in een ander beroep (hoofdstuk 5). In bijlage C zijn bovendien alle gegevens uit het gebruikte databestand onderverdeeld naar deze vier groepen van het onbenutte arbeidspotentieel. Overigens worden deze groepen niet alleen verder onderverdeeld naar de zes regio's die in dit rapport worden onderscheiden, maar volledigheidshalve ook naar de provincies en de 18 voormalige RBA-gebieden ${ }^{17}$.

17. Er dient echter voorzichtig te worden omgesprongen met het trekken van conclusies op het regionale niveau. Voor de zes onderscheiden regio's, maar zeker voor de RBAgebieden geldt dat de steekproefaantallen erg klein zijn. Dit is in het bijzonder het geval voor de kleine groep van werklozen. 
In dit rapport worden vijf vragen behandeld die in het inleidende hoofdstuk zijn aangekondigd, namelijk (1) welke de achtergrondkenmerken zijn van de uitgetreden apothekersassistenten, (2) wat hun redenen zijn geweest om te stoppen met het werk in de openbare apotheek of om een andere baan te zoeken, (3) in welke mate zij bereid zijn tot het aanvaarden van een baan in de openbare apotheek of daarnaar op zoek zijn, (4) wat volgens hen de voornaamste belemmeringen zijn voor een eventuele terugkeer, en (5) wat er toe zou kunnen leiden dat een deel van hen daadwerkelijk terugkeert als apothekersassistent in de openbare apotheek. Hieronder worden eerst de resultaten van de eerste twee vragen samengevat. Vervolgens wordt stilgestaan bij de bereidheid en de belemmeringen van apothekersassistenten buiten de openbare apotheek. Ten slotte worden enkele aanbevelingen voor het beleid ten aanzien van de terugkeer van gediplomeerde apothekersassistenten naar de openbare apotheek geformuleerd.

\section{Achtergrondkenmerken en reden van uittrede}

Van de drie groepen die het onbenutte arbeidspotentieel voor de openbare apotheek vormen, is het aantal niet-participerenden met 8.500 het grootst. Ongeveer tweederde van deze niet-participerenden houdt zich voornamelijk bezig met huishoudelijk werk en de verzorging van de kinderen. Verder ziet ruim 10 procent de studie als voornaamste bezigheid, en is ruim 5 procent arbeidsongeschikt. Meer dan 90 procent heeft een partner die meestal het inkomen verdient, en driekwart heeft minimaal één thuiswonend kind. Van de niet-participerenden die huishoudelijk werk en zorgtaken als belangrijkste bezigheid zien heeft zelfs bijna iedereen een partner, en heeft slechts iets meer dan 5 procent geen kinderen. Meer dan de helft van de jongste kinderen in een gezin is bovendien niet ouder dan 4 jaar. Dit alles roept het beeld op van jonge gezinnen met kinderen en een traditioneel rollenpatroon wat betreft werk en inkomen.

Voor ruim driekwart van de niet-participerenden was het beroep van apothekersassistent het laatste beroep voor de arbeidsmarktuittrede. Toch heeft slechts 55 procent nog na 1994 in de openbare apotheek gewerkt. Hoewel bijna 90 procent van de niet-participerenden meer dan 5 jaar werkervaring heeft, hebben zij hun diploma meestal ruim voor 1990 behaald. Wel dient nog te worden opgemerkt dat 42 procent van de niet-participerenden na hun initiële opleiding tot apothekersassistenten nog een andere (vaak farmaceutische) opleiding heeft gevolgd. Dit alles betekent dat er weliswaar veel werkervaring aanwezig is onder de niet-participerenden, maar dat voor een grote groep de kennis en vaardigheden wat verouderd of 'weggezakt' kunnen zijn.

De helft van de niet-participerenden is gestopt met werken vanwege huishoudelijke werkzaamheden of de zorg voor de kinderen. Hierbij spelen de faciliteiten voor kinderopvang of buitenschoolse opvang geen rol. Het percentage niet-participerenden dat na de arbeidsmarktuittrede het huishoudelijk werk en de zorgtaken als de belangrijkste bezigheid is gaan zien, is echter significant groter, hetgeen duidt op een sterkere traditionele rolverdeling als de meestal vrouwelijke apothekersassistent is gestopt met werken. Verder spelen diverse aan het werk gerelateerde redenen een 
rol, zoals dat het werk niet leuk werd gevonden, dat er een hoge werkdruk heerste, te weinig carrièreperspectief en financieel onaantrekkelijk werk, en te weinig mogelijkheden voor flexibele werktijden en deeltijdwerk. Hoewel er niet een dominante factor bij is, waren deze werkgerelateerde redenen voor ongeveer een vijfde van de nietparticiperenden de belangrijkste reden voor uittrede.

Naast de niet-participerenden is er een relatief kleine groep van ongeveer 1.000 werklozen. Opvallend is dat de leeftijdssamenstelling van de werklozen geheel anders is dan de rest van het onbenutte arbeidspotentieel: meer dan de helft is namelijk vijftigplusser. Van de werklozen heeft 85 procent een partner. Daarnaast heeft bijna de helft minimaal één thuiswonend kind, hetgeen beduidend minder is dan bij de niet-participerenden. Bovendien is ruim een kwart van deze kinderen 15 jaar of ouder. Meer dan viervijfde van de partners van de werkloze apothekersassistenten heeft een voltijdbaan. In het algemeen maken de gemiddeld wat oudere werkloze apothekersassistenten deel uit van een gezin waarin de mannelijke partner werkt, en waarbij er geen of al oudere thuiswonende kinderen zijn.

Samenhangend met de leeftijdsopbouw is het diploma voor apothekersassistent veel langer geleden behaald dan bij de niet-participerenden. Hun werkervaring is echter van recentere datum dan van de niet-participerenden: ongeveer tweederde heeft na 1994 nog in de openbare apotheek gewerkt. Bijna 60 procent heeft een baan als apothekersassistent als laatste baan gehad, hetgeen beduidend minder is als bij de niet-participerenden. Hoewel de meeste werklozen veel werkervaring hebben als apothekersassistent, heeft ongeveer de helft het diploma voor apothekersassistent behaald vóór 1970. Bijna eenderde is onvrijwillig werkloos geworden, en 15 procent is ooit gestopt met werken vanwege huishoudelijke werkzaamheden of de zorg voor de kinderen. Bovendien is 10 procent gestopt met werken in de openbare apotheek vanwege gezondheidsredenen. Ongeveer eenderde van de werklozen is gestopt met het werk in de openbare apotheek vanwege werkgerelateerde redenen zoals de aantrekkelijkheid van het werk zelf, de hoge werkdruk, het geringe carrièreperspectief, de financiële onaantrekkelijkheid, en de te geringe mogelijkheden voor deeltijdwerk. Dit percentage is beduidend hoger dan bij de niet-participerenden.

De werkenden van het onbenutte arbeidspotentieel kunnen worden onderverdeeld in degenen die als apothekersassistent buiten de openbare apotheek werkzaam zijn en degenen die helemaal niet meer als apothekersassistent werkzaam zijn. Deze laatste groep is relatief groot en bestaat uit ca. 6.000 mensen. Daarnaast werken ongeveer 1.000 mensen weliswaar in het beroep van apothekersassistent, maar buiten de openbare apotheek. Van de totale groep van werkenden buiten de openbare apotheek heeft meer dan viervijfde een partner. Bijna 60 procent van de werkenden heeft één of meer thuiswonende kinderen.

Onder de werkenden buiten de openbare apotheek hebben vooral degenen die nog als apothekersassistent werkzaam zijn veel ervaring als apothekersassistent. De meeste werkenden buiten de openbare apotheek hebben hun overstap nog redelijk recent gemaakt. Ongeveer tweederde van degenen die nog als apothekersassistent 
werken, is overgestapt na 1994, tegenover ruim de helft van degenen die niet meer als apothekersassistent werken.

Van groot belang is verder dat maar liefst de helft een aan het werk gerelateerde reden had voor uittrede uit de openbare apotheek, zoals dat het werk niet leuk genoeg was, dat er te weinig carrièreperspectief en een te hoge werkdruk was, en dat de arbeidsvoorwaarden niet aantrekkelijk genoeg waren. Dat laatste heeft betrekking op financiële aspecten, maar ook op de mogelijkheden voor deeltijdwerk. Bijna een vijfde is ooit gestopt met het werk als apothekersassistent in de openbare apotheek vanwege huishoudelijk werk of de verzorging van de kinderen.

\section{Bereidheid tot werken in de openbare apotheek}

De bereidheid van het onbenutte arbeidspotentieel om in de openbare apotheek te gaan werken, verschilt tussen de vier onderscheiden groepen. In tabel 6.1 is dit nog eens aangegeven. Vooral de werkenden buiten de openbare apotheek zijn veel minder bereid om terug te keren. Zij zijn dan ook vaker dan de niet-participerenden en de werklozen van baan gewisseld omdat het werk inhoudelijk of financieel niet aantrekkelijk genoeg was. Het percentage dat bereid is om terug te keren is gerelateerd aan de omvang van de vier groepen zoals weergegeven in hoofdstuk 2 . Zowel het aantal personen met werkervaring in de openbare apotheek, als het aantal personen dat naar schatting bereid is om terug te keren zijn weergegeven ${ }^{18}$. Van de 3.750 personen met ervaring in de openbare apotheek is bijna de helft, ongeveer 1.800 personen, bereid om terug te keren naar de openbare apotheek. Ongeveer 1.000 onder hen zijn potentiële herintreders. Toch geldt voor elk van de groepen, en zeker ook voor de potentiële herintreders dat er de nodige voorwaarden verbonden zijn aan hun terugkeer. Er zal hieronder verder worden ingegaan op de belemmeringen en de voorwaarden die voor elke groep van belang zijn bij een eventuele terugkeer.

Van het totale onbenutte arbeidspotentieel voor de openbare apotheek zijn naar schatting 8.000 personen bereid om in de openbare apotheek te gaan werken. Dit zullen voor een belangrijk deel ook mensen zijn die geen ervaring hebben met het werk in de openbare apotheek. De groep van niet-participerenden is het grootst, gevolgd door de groep werkenden die niet het beroep van apothekersassistent heeft. Het is duidelijk dat het erbij betrekken van mensen die geen ervaring hebben met het werk als apothekersassistent in de openbare apotheek, de omvang van het onbenutte arbeidspotentieel aanzienlijk vergroot. Van belang is echter dat deze mensen mogelijkerwijs een lagere bereidheid hebben om te gaan werken in de openbare apotheek, omdat zij in een eerdere fase van hun loopbaan ook niet ervoor hebben gekozen om te gaan werken in de openbare apotheek. Dit betekent dat de in

18. Dit is het aantal personen dat voorkomt in het pensioenbestand van het PMA. Deze groep heeft zeker ervaring in de openbare apotheek, maar er zijn waarschijnlijk ook veel personen in de totale groep van het onbenutte arbeidspotentieel die ervaring hebben als apothekersassistent, maar niet in het PMA-bestand voorkomen. Hun aantal is echter niet bekend. Zie ook voetnoot 3 in hoofdstuk 1. 
tabel 6.1 veronderstelde bereidheid onder deze mensen om terug te keren naar de openbare apotheek mogelijk te optimistisch is.

Tabel 6.1

Bereidheid van het onbenutte arbeidspotentieel om te gaan werken of terug te keren naar de openbare apotheek (OA), 2001

\begin{tabular}{|c|c|c|c|c|c|}
\hline Par & $\begin{array}{l}\text { Niet- } \\
\text { perend }\end{array}$ & Werkloos & $\begin{array}{r}\text { Werkend } \\
\text { als AA }\end{array}$ & $\begin{array}{r}\text { Werkend } \\
\text { anders }\end{array}$ & Totaal \\
\hline Bereidheid in \% & 56 & 63 & 42 & 37 & 48 \\
\hline $\begin{array}{l}\text { Aantal met ervaring } \\
\text { in } \mathrm{OA}^{*} \\
\text { waarvan bereid }\end{array}$ & $\begin{array}{r}1.740 \\
970\end{array}$ & $\begin{array}{r}110 \\
70\end{array}$ & $\begin{array}{l}610 \\
250\end{array}$ & $\begin{array}{r}1.290 \\
480\end{array}$ & $\begin{array}{l}3.750 \\
1.800\end{array}$ \\
\hline $\begin{array}{l}\text { Totaal aantal } \\
\text { waarvan bereid }^{* * *}\end{array}$ & $\begin{array}{l}8.500 \\
5.000\end{array}$ & $\begin{array}{r}1.000 \\
500\end{array}$ & $\begin{array}{r}1.000 \\
500\end{array}$ & $\begin{array}{l}6.000 \\
2.500\end{array}$ & $\begin{array}{r}16.500 \\
8.000\end{array}$ \\
\hline
\end{tabular}

* $\quad$ Afgerond op eenheden van 10

** Afgerond op eenheden van 500 .

*** Onder de veronderstelling dat het percentage dat bereid is terug te keren ook van toepassing is op personen die niet in het PMA-bestand voorkomen.

Bron: ROA/PMA/CBS

\section{Belemmeringen bij terugkeer}

Over het algemeen zijn niet-participerenden veel meer belemmerd door de huishoudsituatie vanwege de huishoudelijke taken en verzorging van de kinderen dan de werklozen en de werkenden. Toch wil ruim de helft wel terugkeren naar de openbare apotheek. De belangrijkste voorwaarden hierbij zijn dat men niet onmiddellijk beschikbaar is en dat veruit het grootste deel niet meer dan twee dagen wil werken. Ook andere voorwaarden in verband met de werktijden, zoals voldoende mogelijkheden voor flexibele werktijden en niet teveel onregelmatige diensten zijn daarbij van belang.

De werklozen vertonen de grootste bereidheid om weer aan de slag te gaan in de openbare apotheek. Zij zijn dan ook relatief vaak onvrijwillig werkloos geworden. Verder zijn zij duidelijk actiever op zoek naar een baan dan de niet-participerenden, en staat ruim eenderde van hen ingeschreven bij het arbeidsbureau. Zij lijken ook meer bereid te zijn om te reizen naar het werk. Toch zijn zij, evenals de nietparticiperenden, in slechts geringe mate bereid om meer dan twee dagen per week te werken. Voorts zien zij de diverse andere aspecten in verband met de werktijden, zoals flexibele werktijden en onregelmatige diensten, als een mogelijke belemmering voor de terugkeer naar de openbare apotheek. Bovendien wensen zij beduidend hogere netto uurlonen dan de niet-participerenden. Dit kan gedeeltelijk te maken hebben met de gemiddeld hogere leeftijd en de grotere werkervaring van de werklozen, maar ook met de alternatieve inkomsten uit bijvoorbeeld een werkloosheidsuitkering. Het is echter vooral de hoge werkdruk die hen ervan kan weerhouden om aan de slag te gaan, en mogelijk te blijven, als apothekersassistent in de openbare apotheek. 
De werkenden buiten de openbare apotheek lijken het meest in staat te zijn om weer te gaan werken in de openbare apotheek, maar zijn daartoe tegelijkertijd ook het minst bereid. Zij zien vooral de financiële onaantrekkelijkheid en het gebrek aan carrièreperspectief in de openbare apotheek als belemmeringen voor hun terugkeer. Degenen die als apothekersassistent buiten de openbare apotheek werken vinden het werk in de openbare apotheek doorgaans minder leuk, terwijl degenen die in een ander beroep dan apothekersassistent werkzaam zijn het werk als apothekersassistent doorgaans minder aantrekkelijk vinden. Degenen die bereid zijn terug te keren willen minder uren gaan werken dan ze nu werken, en willen een hoger netto uurloon gaan verdienen. Hun gewenste netto uurloon ligt gemiddeld nog hoger dan dat van de werklozen.

\section{Aanbevelingen bij het aantrekken van het onbenutte arbeidspotentieel}

Bij sollicitatieprocedures of een wervings- of imagocampagne voor de openbare apotheek kan men inspelen op de achtergrondkenmerken en voorkeuren van de geïnteresseerde apothekersassistenten buiten de openbare apotheek. Hiertoe zijn de volgende aanbevelingen geformuleerd.

1. Bij een wervingscampagne zijn de verschillen tussen de vier onderscheiden groepen van het onbenutte arbeidspotentieel veel belangrijker dan de verschillen tussen de regio's.

Om personeel te werven uit het onbenutte arbeidspotentieel dient men zich bewust te zijn van de verschillen tussen de vier onderscheiden groepen. Er bestaan belangrijke verschillen in achtergrondkenmerken tussen deze groepen. Hierbij is het van belang dat men weet welke kandidaten er verwacht kunnen worden als één van de vier groepen wordt benaderd. Bovendien heeft elke groep een bepaalde voorkeur ten aanzien van de arbeidsvoorwaarden. Om een wervings- of imagocampagne te laten slagen dient men te weten wat de verschillen in voorkeuren zijn zodat hierop kan worden ingespeeld. Er bestaan geen grote significante verschillen tussen regio's wat betreft de omvang en samenstelling van de verschillende groepen van het onbenutte arbeidspotentieel.

2. Potentiële herintreders vertonen grote bereidheid om terug te keren naar de openbare apotheek, maar zijn veelal niet op korte termijn beschikbaar. Het onderhouden van regelmatig contact met de potentiële herintreders kan nuttig zijn om als openbare apotheek in beeld te blijven bij deze groep.

Voor de niet-participerenden waren het verrichten van huishoudelijk werk en de zorgtaken in het gezin de belangrijkste reden waarom ze gestopt zijn met het werk in de openbare apotheek. Als de kinderen ouder worden kunnen zij weer interesse krijgen om buitenshuis te gaan werken. Voor velen zijn dan waarschijnlijk voldoende alternatieven buiten de openbare apotheek voor handen. Van belang is derhalve dat de openbare apotheek in beeld is als het moment voor een eventuele herintrede is aangebroken. 
3. Werkloze apothekersassistenten kunnen via de normale wervingskanalen zoals personeelsadvertenties en het arbeidsbureau goed worden benaderd. Hierbij dient rekening gehouden te worden met de gemiddeld hogere leeftijd en de grotere werkervaring van werklozen gecombineerd met hogere financiële voorwaarden.

Werklozen zijn veel actiever dan niet-participerenden op zoek naar een baan en staan ook relatief vaak ingeschreven bij het arbeidsbureau. Ze kunnen derhalve relatief snel via deze gebruikelijke weg worden benaderd.

4. De diverse aspecten in verband met de werktijden, waaronder voldoende mogelijkheden voor deeltijdwerk en flexibele werktijden, en niet teveel onregelmatige diensten, zijn over het algemeen erg belangrijk bij een terugkeer. Concessies ten aanzien van deze aspecten kunnen potentiële herintreders, werklozen en werkenden buiten de openbare apotheek over de streep trekken om een baan in de openbare apotheek te aanvaarden.

Vooral deeltijdwerk van maximaal twee dagen per week is van groot belang voor werklozen en niet-participerenden. De vraag is uiteraard of werkgevers dit binnen hun openbare apotheek willen en kunnen realiseren voor hun werknemers. De kosten die dan gemaakt moeten worden voor het aantrekken en inwerken van personeel zijn dan immers relatief groot voor het beperkte aantal uren dat iemand in dienst is. Opvallend is verder ook dat flexibele werktijden van groot belang zijn, maar dat teveel onregelmatige diensten, ook een vorm flexibele werktijden maar dan ten gunste van de werkgever, een belangrijke belemmering kunnen zijn voor nietparticiperenden. Dit is uiteraard goed te begrijpen gezien de huishoudsituatie, met vaak jonge kinderen, waarin niet-participerenden verkeren.

5. Het werk als apothekersassistent in de openbare apotheek is aantrekkelijk vanwege de inhoud van het werk, en vanwege de dienstverlening aan klanten en de werksfeer in de openbare apotheek. De arbeidsvoorwaarden en het carrièreperspectief zijn daarentegen geen aantrekkelijke aspecten. Hiermee dient bij wervings- of imagocampagnes rekening gehouden te worden.

Deze aanbeveling geldt voor zowel niet-participerenden en werklozen als werkenden buiten de openbare apotheek. De arbeidsvoorwaarden en het carrièreperspectief zijn duidelijk geen aspecten waarmee in eerste instantie in een imagocampagne 'gescoord' kan worden. Van belang is echter dat men goed moet weten hoe het met de arbeidsvoorwaarden is gesteld in de openbare apotheek. Indien deze niet onderdoen voor de arbeidsvoorwaarden elders, dan kan een imagocampagne zinvol zijn om de doelgroep op deze realiteit te wijzen, en hen van het tegendeel te overtuigen. Hetzelfde geldt voor het carrièreperspectief. Overigens kan men natuurlijk naar aanleiding van een vergelijking van de arbeidsvoorwaarden en het carrièreperspectief tussen een functie bij de openbare apotheek met andere functies buiten de openbare apotheek, ook besluiten om de arbeidsvoorwaarden en het carrièreperspectief voor apothekersassistenten op een aantal punten te verbeteren. 
6. De werkenden buiten de openbare apotheek zijn over het algemeen het minst bereid om terug te keren naar de openbare apotheek. Omdat zij echter een aantrekkelijke doelgroep vormen kan het de moeite waard zijn om te onderzoeken of (gedeeltelijk) aan hun wensen tegemoet kan worden gekomen. Ook kan dit mogelijk verdere uitstroom van mensen naar banen buiten de openbare apotheek (gedeeltelijk) voorkomen.

Een gedeelte van de werkenden buiten de openbare apotheek vindt het werk als apothekersassistent of het werk in de openbare apotheek gewoonweg minder leuk. Mogelijkerwijs heeft dit iets te maken met het gebrek aan carrièreperspectief of de hoge werkdruk. Om verdere uitstroom te beperken zou hieraan iets gedaan kunnen worden. Verder wensen de werkenden buiten de openbare apotheek hogere netto uurlonen dan zij in hun huidige baan verdienen, en wensen zij meer minder uren per week te gaan werken bij een eventuele terugkeer.

7. Over het algemeen vinden apothekersassistenten die bereid zijn terug te keren naar de openbare apotheek het noodzakelijk om een opfriscursus te volgen.

Dit geldt voor ongeveer tweederde van degenen die bereid zijn terug te keren naar de openbare apotheek, met uitzondering van degenen die als apothekersassistent buiten de openbare apotheek werken: van hen vindt slechts eenderde een opfriscursus noodzakelijk. Vooral cursussen met betrekking tot geneesmiddelenkennis, informatieverstrekking over geneesmiddelen en het recepteren en bereiden van geneesmiddelen worden van belang geacht. Daarnaast vindt men ook computervaardigheden belangrijk. 


\section{Bijlage A. Steekproeftrekking en weging}

In het kader van het voorgestelde onderzoek is in mei 2001 door bureau Intomart een enquête uitgevoerd (zie bijlage $B$ ) onder personen uit het pensioenbestand van het Pensioenfonds Medewerkers Apotheken (PMA). Dit zijn alle personen die ooit als apothekersassistent in de openbare apotheek hebben gewerkt, toen pensioenrechten hebben opgebouwd, en deze rechten nog steeds bezitten. Dit bestand zal in het vervolg als de steekproef worden aangeduid, omdat het een deel van het totale onbenutte arbeidspotentieel betreft. Het bestand is voor het PMA echter wel het integrale bestand van personen die niet meer in de openbare apotheek werken, maar wel nog pensioenrechten hebben. Alle personen die vanaf 1 juli 2000 door hun werkgever zijn afgemeld als werknemer bij een openbare apotheek zijn niet meegenomen in de steekproefselectie door de PMA. De reden hiervoor is dat de meeste van deze apothekersassistenten een overstap maken naar een andere openbare apotheek, waarbij het enige tijd duurt voordat hun nieuwe werkgever hen weer aanmeldt bij het PMA. Bovendien konden personen die jonger dan 25 jaar oud waren tot enige tijd geleden geen pensioenrechten opbouwen. Hierdoor is deze groep mogelijk enigszins ondervertegenwoordigd in de steekproef.

Het bovenstaande betekent dat van de 16.500 personen in het onbenutte arbeidspotentieel, zoals dat is vastgesteld in hoofdstuk 2, ongeveer 3.750 personen zijn geselecteerd. Deze selectie bestaat uit alle personen die niet in de openbare apotheek werken, maar wel voorkomen in het pensioenbestand van het PMA. Van het grootste deel van het onbenutte arbeidspotentieel voor de openbare apotheek is derhalve weinig bekend ${ }^{19}$. Van de geselecteerde personen zijn op basis van de PMAgegevens slechts geslacht, leeftijd, woonregio, intrede- en uittrededatum bekend. Deze administratieve gegevens dienen in dit rapport als aanvulling op de enquêtegegevens.

Ongeveer de helft van de steekproefpersonen heeft op de enquête gerespondeerd. Deze personen zullen worden aangeduid als de ongewogen responsgroep. Op basis van drie persoonskenmerken is deze ongewogen responsgroep door middel van wegingsfactoren representatiever gemaakt voor de steekproef. De weging is gebaseerd op geslacht, leeftijd en regio, en resulteert in de zogenaamde gewogen responsgroep. In tabel A.1 staat per achtergrondkenmerk het responspercentage vermeld, dat wil zeggen: de verhouding tussen de ongewogen responsgroep en de totale steekproef.

19. Met behulp van gegevens uit de Enquête Beroepsbevolking (EBB) van het Centraal Bureau voor de Statistiek (CBS) is het onbenutte arbeidspotentieel voor de openbare apotheek niet helemaal af te bakenen. Bovendien zijn mede vanwege de ondergrenzen die het CBS hanteert, slechts in beperkte mate achtergrondkenmerken beschikbaar over het onbenutte arbeidspotentieel. 
Tabel A. 1

Omvang van de steekproef en de respons naar achtergrondkenmerk

\begin{tabular}{|c|c|c|c|}
\hline Kenmerk & $\begin{array}{r}\text { Responsgroep } \\
\text { (ongewogen) } \\
\text { aantal }\end{array}$ & $\begin{array}{r}\text { Steekproef } \\
\text { aantal }\end{array}$ & $\begin{array}{r}\text { Respons } \\
\%\end{array}$ \\
\hline \multicolumn{4}{|l|}{ Geslacht } \\
\hline Man & 17 & 72 & 24 \\
\hline Vrouw & 1.819 & 3.674 & 50 \\
\hline \multicolumn{4}{|l|}{ Leeftijdscohort (in jr.) } \\
\hline $15-19$ & 0 & 1 & 0 \\
\hline $20-24$ & 111 & 191 & 58 \\
\hline $25-29$ & 171 & 271 & 63 \\
\hline $30-34$ & 392 & 613 & 64 \\
\hline $35-39$ & 548 & 974 & 56 \\
\hline $40-44$ & 281 & 698 & 40 \\
\hline $45-49$ & 157 & 403 & 39 \\
\hline $50-54$ & 116 & 375 & 32 \\
\hline $55-59$ & 60 & 220 & 27 \\
\hline $60-64$ & 0 & 0 & - \\
\hline$>64$ & 0 & 0 & - \\
\hline \multicolumn{4}{|l|}{ Regio } \\
\hline Noord-Nederland & 147 & 323 & 46 \\
\hline Oost-Nederland & 383 & 760 & 50 \\
\hline Noordwest-Nederland & 266 & 585 & 45 \\
\hline Middenwest-Nederland & 358 & 752 & 48 \\
\hline Zuidwest-Nederland & 380 & 719 & 53 \\
\hline Zuidoost-Nederland & 302 & 607 & 50 \\
\hline Totaal & 1.836 & 3.746 & 49 \\
\hline
\end{tabular}

Bron: ROA

Tabel A.2 toont de verdeling naar geslacht, leeftijd en regio voor de ongewogen responsgroep, de gewogen responsgroep (gewogen op basis van geslacht, leeftijd en regio) en de totale steekproef (uit het pensioenbestand). Het blijkt dat de gewogen responsgroep een bruikbare afspiegeling vormt van de apothekersassistenten buiten de openbare apotheek. Dit vooral ook omdat mannen, ongeacht de leeftijd, voor de apothekersassistenten een relatief onbeduidende minderheid vormen.

Tabel A.2 laat zien dat apothekersassistenten voornamelijk vrouw zijn (98\%), en voornamelijk in de leeftijd van 30 tot 44 jaar (61\%). Verder is een op RBA-gebieden gebaseerde regioverdeling weergegeven. De regio Noord-Nederland is wat betreft het aantal steekproefpersonen beduidend kleiner dan de overige regio's. 
Tabel A.2

Kenmerkverdeling van de steekproef en de ongewogen en gewogen responsgroep

\begin{tabular}{|c|c|c|c|}
\hline Kenmerk & $\begin{array}{r}\text { Responsgroep } \\
\text { (ongewogen) } \\
\%\end{array}$ & $\begin{array}{r}\text { Responsgroep } \\
\text { (gewogen) } \\
\%\end{array}$ & $\begin{array}{r}\text { Steekproef } \\
\%\end{array}$ \\
\hline \multicolumn{4}{|l|}{ Geslacht } \\
\hline Man & 99 & 98 & 98 \\
\hline Vrouw & 1 & 2 & 2 \\
\hline Totaal & 100 & 100 & 100 \\
\hline \multicolumn{4}{|l|}{ Leeftijdscohorten (in jaren) } \\
\hline $15-19$ & 0 & 0 & 0 \\
\hline $20-24$ & 6 & 5 & 5 \\
\hline $25-29$ & 9 & 7 & 7 \\
\hline $30-34$ & 21 & 16 & 16 \\
\hline $35-39$ & 30 & 26 & 26 \\
\hline $40-44$ & 15 & 19 & 19 \\
\hline $45-49$ & 9 & 11 & 11 \\
\hline $50-54$ & 6 & 10 & 10 \\
\hline $55-59$ & 3 & 6 & 6 \\
\hline $60-64$ & 0 & 0 & 0 \\
\hline$>64$ & 0 & 0 & 0 \\
\hline Totaal & 100 & 100 & 100 \\
\hline \multicolumn{4}{|l|}{ Regio } \\
\hline Noord-Nederland & 8 & 8 & 9 \\
\hline Oost-Nederland & 21 & 20 & 20 \\
\hline Noordwest-Nederland & 14 & 16 & 16 \\
\hline Middenwest-Nederland & 19 & 21 & 20 \\
\hline Zuidwest-Nederland & 21 & 19 & 19 \\
\hline Zuidoost-Nederland & 16 & 16 & 16 \\
\hline Totaal & 100 & 100 & 100 \\
\hline
\end{tabular}

Bron: ROA 



\section{Bijlage B. Vragenlijst}

\section{$\rightarrow$ INTOMART}

\section{UITGETREDEN APOTHEKERSASSISTENTEN}

Toelichting: wij verzoeken u steeds maar één antwoord aan te kruisen, tenzij uitdrukkelijk anders wordt vermeld. Let goed op naar welke vraag u wordt doorverwezen. Een aantal vragen hoeft u misschien niet in te vullen. Uw persoonlijke gegevens worden alleen gebruikt ten behoeve van de loterij en een eventuele herinneringsbrief.

$\overline{1 .} \quad$ In welk jaar heeft u uw opleiding tot apothekersassistent afgerond?

2. Heeft u na uw opleiding tot apothekersassistent nog een andere opleiding gevolgd? $15 \mathrm{~L} 1$
$1 \square$ ja
$2 \square$ nee $\rightarrow \quad$ NAAR VRAAG 5

3. Heeft u een diploma gehaald voor (één van) deze opleiding(en)?

$1 \square$ ja

$2 \square$ nee $\rightarrow \quad$ NAAR VRAAG 5

4. Wat is het niveau en de richting van de laatste met een diploma afgesloten opleiding? $17 \mathrm{~L}$ NIVEAU RICHTING
$1 \square \mathrm{MBO}$
$2 \square \mathrm{HBO}$
$\square$ farmaceutisch
$3 \square$ wo
$\square$ gezondheidszorg overig
$4 \quad \square$ overig
$\square$ economisch, administratief of commerciee
$4 \square$ overig

$\square$ niveau onbekend

5. In welk jaar heeft u voor het laatst betaald werk verricht? Vul 2001 in als u momenteel werkt.

6. Wat is de belangrijkste reden dat u gestopt bent met uw werk als apothekersassistent in de openbare apotheek? (LET OP: SLECHTS EEN ANTWOORD MOGELIJK)

$1 \square$ Indien niet van toepassing $\rightarrow$ GA NAAR EINDE ALS U INMIDDELS WEER WERKT ALS

APOTHEKERSASSISTENT IN EEN OPENBARE APOTHEEK zorgtaken

$3 \square$ te weinig faciliteiten voor kinderopvang of
buitenschoolse opvang

$9 \square$ te weinig mogelijkheden voor deeltijdwerk

studie

$5 \square$ werk was niet leuk genoeg

$6 \quad \square$ werk bood te weinig carrièreperspectief

$7 \square$ werk was financieel niet aantrekkelijk genoeg

$10 \square$ te weinig mogelijkheden voor flexibele werktijden

$11 \square$ onregelmatige diensten

$12 \square$ hoge werkdruk

$13 \square$ onvrijwillig werkloos geworden

$14 \square$ gezondheid

$8 \square$ reistijd naar het werk

$15 \square$ overig 
7. Welk werk verricht(te) $\mathrm{u}$ in uw huidige of laatste baan?

$1 \square$ werk als apothekersassistent

$2 \square$ werk in een ander beroep binnen de gezondheidszorg

$3 \square$ werk in een economische, administratieve of commerciële functie

$4 \square$ overig werk

8. Hoeveel jaren heeft $u$ in totaal als apothekersassistent gewerkt?

(A.U.B. AFRONDEN OP HELE JAREN)

9. Heeft $\mathrm{u}$ uw werk als apothekersassistent met plezier gedaan?

$1 \square$ ja

$2 \square$ nee

28L1

10. Zou u achteraf gezien ook voor de opleiding tot apothekersassistent gekozen hebben? Indien 'nee': waarom niet? (MEERDERE ANTWOORDEN MOGELIJK)

$1 \square$ ja

$\square$ nee, omdat:

$1 \square$ opleiding is niet interessant genoeg

$1 \square$ andere opleidingen sluiten beter aan bij mijn huidige werk

$1 \square$ ik heb niets of weinig aan de opleiding gehad

$1 \square$ werk als apothekersassistent is niet leuk genoeg

$1 \square$ werk als apothekersassistent biedt te weinig carrièreperspectief

$1 \square$ werk als apothekersassistent is financieel niet aantrekkelijk genoeg

$1 \square$ onregelmatige diensten bij het werk als apothekersassistent zijn niet aantrekkelijk

$1 \square$ hoge werkdruk bij het werk als apothekersassistent is niet aantrekkelijk

$1 \square$ overige arbeidsvoorwaarden voor apothekersassistenten zijn niet aantrekkelijk

$1 \square$ opleiding is niet interessant genoeg

$1 \square$ overig

$1 \square$ huishoudelijk werk / verzorging van kinderen

ANTWOORDEN MOGELIJK)

$2 \square$ werkend

$8 \square$ studerend

$4 \square$ werkloos

$16 \square$ arbeidsongeschikt

$32 \square$ overig

12. Hoeveel uren besteedt u gemiddeld per week aan betaald werk? Indien u geen betaald werk verricht, vult $u$ hier 0 uur in.

.................... uren

13. Wat is uw persoonlijke netto inkomen gemiddeld per maand?

$\mathrm{fl}$

14. Heeft u een partner met wie u een gezamenlijke huishouding voert?

$1 \quad \square$ ja

$2 \square$ nee $\rightarrow \quad$ NAAR VRAAG 17

15. Wat is de persoonlijke situatie van uw partner? (MEERDERE ANTWOORDEN MOGELIJK)

$1 \square$ werkzaam in een voltijdbaan

$2 \square$ werkzaam 32 uur of minder

$4 \square$ huishoudelijk werk / verzorging van kinderen

$16 \square \mathrm{VUT} /$ pensioen

$32 \square$ arbeidsongeschikt

$8 \square$ werkloos

$64 \square$ overig

16. Wat is het totale netto inkomen van u en uw partner gemiddeld per maand?

$\mathrm{fl}$ 
17. Zou u weer betaald werk willen verrichten als apothekersassistent in een openbare apotheek?

$\square \mathrm{ja}$, onder bepaalde voorwaarden of op termijn

$3 \square$ nee $\rightarrow$ NAAR VRAAG 28

18. Hoeveel uren zou u dan per week willen werken?

uren

19. Hoeveel zou u voor dat aantal uren werk netto per maand moeten verdienen om het werk te aanvaarden?

20. Welke aspecten van het werk als apothekersassistent in een openbare apotheek trekken $u$ het meest aan? (MEERDERE ANTWOORDEN MOGELIJK)

$\begin{array}{lllll}1 \square \begin{array}{l}\text { kennis van geneesmiddelen, ziekte en } \\ \text { gezondheid }\end{array} & 66 & 1 \square \text { leuke werksfeer en prettige omgang } & 71 \\ 1 \square \text { met collega's } & & 72 \\ 1 \square \text { greiding van geneesmiddelen } & 67 & 1 \square \text { financiële aantrekkelijkheid } & 72 \\ \text { apothekersassistent } & 68 & 1 \square \text { aantrekkelijkheid van overige arbeids- } & 73 \\ 1 \square \text { grote zelfstandigheid als apothekersassistent } & 69 & 1 \square \text { overig } & 74 \\ 1 \square \text { dienstverlening aan klanten } & 70 & 1 \square \text { geen } & 75\end{array}$

21. Zou u binnen 4 weken kunnen beginnen met werken?

$1 \square$ ja

$2 \square$ nee

$3 \square$ niet van toepassing (als $u$ al werk heeft of geen behoefte heeft aan betaald werk)

22. Heeft u de laatste drie maanden naar (ander) werk gezocht?

$1 \square$ ja

$2 \square$ nee

$77 L 1$

23. Indien u staat ingeschreven bij het Arbeidsbureau, hoe lang staat u dan ingeschreven?

(1)

$99 \square$ sta niet ingeschreven bij het Arbeidsbureau

$78 \mathrm{~L} 2$

24. Wat is de maximale reistijd die $u$ acceptabel vindt / zou vinden om op uw werkplek aan te komen? (enkele reis in minuten)

...................... minuten

25. Zou u sneller een functie accepteren indien u mogelijkheden krijgt / zou krijgen van uw werkgever om uw werktijden flexibel in te delen?
$1 \square$ ja
$2 \square$ nee

$83 L 1$

26. Denkt $u$ dat het noodzakelijk is een opfriscursus te volgen als $u$ als apothekersassistent aan de slag wilt?
$1 \square$ ja
$2 \square$ nee $\rightarrow$ NAAR VR. 28
$3 \square$ niet van toepassing $\rightarrow$ NAAR VR. 28

27. Op welk terrein zou u een dergelijke cursus willen volgen? (MEERDERE ANTWOORDEN MOGELIJK)

$1 \square$ geneesmiddelenkennis

$1 \square$ communicatieve vaardigheden en omgangskunde

$1 \square$ informatieverstrekking over geneesmiddelen

$1 \square$ computervaardigheden

$\begin{array}{llll}85 & 1 & \square \text { recepteren en bereiden van genees- } & 89 \\ 86 & & \text { middelen } & \\ & 1 & \square \text { kennis van ziektebeelden } & 90 \\ 87 & 1 & \square \text { stage in een apotheek } & 91 \\ & 1 & 1 & \square \text { niet van toepassing (niet nodig of niet } \\ \text { bereid om cursus te volgen) } & 92\end{array}$


28. Welke redenen weerhouden $u$ ervan / zouden $u$ ervan weerhouden om als apothekersassistent in een openbare apotheek te werken? (MEERDERE ANTWOORDEN MOGELIJK)

$\begin{array}{llr}1 & \square \text { zorg voor de kinderen, huishoudelijk werk en/of andere zorgtaken } & 93 \\ 1 & \square \text { te weinig faciliteiten voor kinderopvang of buitenschoolse opvang } & 94 \\ 1 & \text { geen behoefte aan betaald werk } & 95 \\ 1 & \square \text { studie } & 96 \\ 1 & \text { het levert financieel voor mij niet genoeg op } & 97 \\ 1 & \text { reistijd naar het werk } & 98 \\ 1 & \text { te weinig mogelijkheden voor deeltijdwerk } & 99 \\ 1 & \text { te weinig mogelijkheden voor flexibele werktijden } & 100 \\ 1 & \text { onregelmatige diensten } & 101 \\ 1 & \text { hoge werkdruk } & 102 \\ 1 & \square \text { het werken als apothekersassistent is minder leuk dan ander werk } & 103 \\ 1 & \text { het werken bij een openbare apotheek is minder leuk dan elders } & 104 \\ 1 & \square \text { het werk biedt te weinig carrièreperspectief } & 105 \\ 1 & \text { ik kon tot op heden geen geschikt werk als apothekersassistent vinden } & 106 \\ 1 & \square \text { mijn noodzakelijke kennis en vaardigheden voor het werk als apothekersassistent zijn in de loop der tijd } & 107 \\ 1 & \text { aanzienlijk afgenomen } & \\ 1 & \text { gezondheid } & 108 \\ 1 & \text { overig } & 109 \\ 1 & \text { geen of niet van toepassing } & 110\end{array}$

29. Heeft u thuiswonende kinderen?

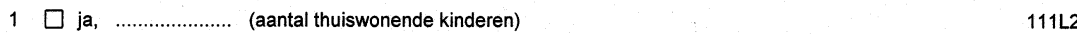

$0 \square$ nee $\rightarrow$ GA NAAR HET EINDE VAN DEZE VRAGENLIJST

30. Hoe oud is uw jongste thuiswonende kind? (A.U.B. AFRONDEN OP HELE JAREN)

...................... jaar

31. Speelt voor u de beschikbaarheid van plaatsen voor kinderopvang of buitenschoolse opvang een rol bij de beslissing om eventueel werk te accepteren?

$1 \square$ ja

$2 \square$ nee

32. Spelen voor u de kosten van kinderopvang of buitenschoolse opvang een rol bij de beslissing om eventueel werk te accepteren?

$1 \square$ ja

$2 \square$ nee

$116 \mathrm{~L} 1$

Dit is het einde van de vragenlijst. Wilt u de vragenlijst a.u.b. zo snel mogelijk in de bijgesloten retourenvelop doen en naar Intomart opsturen? Een postzegel is niet nodig.

Hartelijk bedankt voor uw medewerking 


\section{Bijlage C. Statistische Bijlage}

Tabel 1

Geslacht

\begin{tabular}{lccccr}
\hline & $\begin{array}{c}\text { niet- } \\
\text { participerend } \\
\%\end{array}$ & $\begin{array}{c}\text { werkloos } \\
\%\end{array}$ & $\begin{array}{c}\text { werkend } \\
\text { als AA } \\
\%\end{array}$ & $\begin{array}{c}\text { werkend ander } \\
\text { beroep } \\
\%\end{array}$ & $\begin{array}{c}\text { totaal } \\
\%\end{array}$ \\
\hline Man & 1 & & 5 & 3 & 2 \\
Vrouw & 99 & 100 & 95 & 97 & 98 \\
Totaal & 100 & 100 & 100 & 100 & 100 \\
Aantal & 1735 & 114 & 605 & 1293 & 3747 \\
\hline
\end{tabular}

Tabel 2

Gemeentegrootte

\begin{tabular}{lccccr}
\hline & $\begin{array}{c}\text { niet- } \\
\text { participerend } \\
\%\end{array}$ & $\begin{array}{c}\text { werkloos } \\
\%\end{array}$ & $\begin{array}{c}\text { werkend } \\
\text { als AA } \\
\%\end{array}$ & $\begin{array}{c}\text { werkend } \\
\text { ander beroep } \\
\%\end{array}$ & $\begin{array}{c}\text { totaal } \\
\%\end{array}$ \\
\hline tot 5.000 inwoners & 2 & & 2 & 1 & 2 \\
$5.000-10.000$ inwoners & 9 & 11 & 14 & 10 & 10 \\
$10.000-20.000$ inwoners & 27 & 23 & 24 & 25 & 25 \\
$20.000-50.000$ inwoners & 30 & 21 & 23 & 25 & 27 \\
$50.000-100.000$ inwoners & 17 & 27 & 17 & 15 & 16 \\
100.000 inwoners of meer & 12 & 12 & 14 & 18 & 14 \\
Den Haag & 2 & & 1 & 2 & 2 \\
Rotterdam & 2 & & 2 & 2 & 2 \\
Amsterdam & 1 & 6 & 4 & 3 & 100 \\
Totaal & 100 & 100 & 100 & 100 & 3747 \\
Aantal & 1735 & 114 & 605 & 1293 & \\
\end{tabular}

Tabel 3

Provincie

\begin{tabular}{|c|c|c|c|c|c|}
\hline & $\begin{array}{c}\text { niet- } \\
\text { participerend } \\
\% \\
\end{array}$ & werkloos & $\begin{array}{c}\text { werkend als } \\
\text { AA } \\
\% \\
\end{array}$ & $\begin{array}{c}\text { werkend } \\
\text { ander } \\
\text { beroep } \\
\% \\
\end{array}$ & totaal \\
\hline $\begin{array}{l}\text { Groningen } \\
\text { Friesland } \\
\text { Drenthe } \\
\text { Overijssel } \\
\text { Gelderland } \\
\text { Utrecht } \\
\text { Noord-Holland } \\
\text { Zuid-Holland } \\
\text { Zeeland } \\
\text { Noord-Brabant } \\
\text { Limburg } \\
\text { Grote steden (A'dam, R'dam, } \\
\text { Den Haag) } \\
\text { Flevoland } \\
\text { Totaal }\end{array}$ & $\begin{array}{r}3 \\
3 \\
3 \\
7 \\
13 \\
8 \\
13 \\
18 \\
1 \\
16 \\
9 \\
\\
4 \\
2 \\
100\end{array}$ & $\begin{array}{r}3 \\
4 \\
3 \\
8 \\
10 \\
4 \\
30 \\
18 \\
\\
8 \\
7\end{array}$ & $\begin{array}{r}4 \\
4 \\
3 \\
5 \\
11 \\
5 \\
13 \\
20 \\
3 \\
15 \\
7\end{array}$ & $\begin{array}{r}3 \\
2 \\
2 \\
8 \\
12 \\
7 \\
16 \\
16 \\
1 \\
17 \\
8\end{array}$ & $\begin{array}{r}3 \\
3 \\
3 \\
7 \\
12 \\
7 \\
14 \\
18 \\
1 \\
16 \\
8\end{array}$ \\
\hline Aantal & 1735 & 114 & 605 & 1293 & 3747 \\
\hline
\end{tabular}


Tabel 4

Regio

\begin{tabular}{lccccc}
\hline & $\begin{array}{c}\text { niet- } \\
\text { participerend } \\
\%\end{array}$ & $\begin{array}{c}\text { werkloos } \\
\%\end{array}$ & $\begin{array}{c}\text { werkend } \\
\text { als AA } \\
\%\end{array}$ & $\begin{array}{c}\text { werkend } \\
\text { ander beroep } \\
\%\end{array}$ & $\begin{array}{c}\text { totaal } \\
\%\end{array}$ \\
\hline $\begin{array}{l}\text { Noord-Nederland } \\
\text { Oost-Nederland }\end{array}$ & 9 & 10 & 11 & 6 & 8 \\
Noordwest-Nederland & 21 & 17 & 17 & 20 & 20 \\
Middenwest-Nederland & 22 & 35 & 19 & 18 & 16 \\
Zuidwest-Nederland & 18 & 16 & 18 & 21 & 21 \\
Zuidoost-Nederland & 18 & 13 & 23 & 19 & 19 \\
Totaal & 100 & 100 & 13 & 15 & 16 \\
& 100 & & 100 & 100 & 100 \\
Aantal & 1735 & 114 & 605 & 1293 & 3747 \\
\hline
\end{tabular}

Tabel 5

RBA-gebied

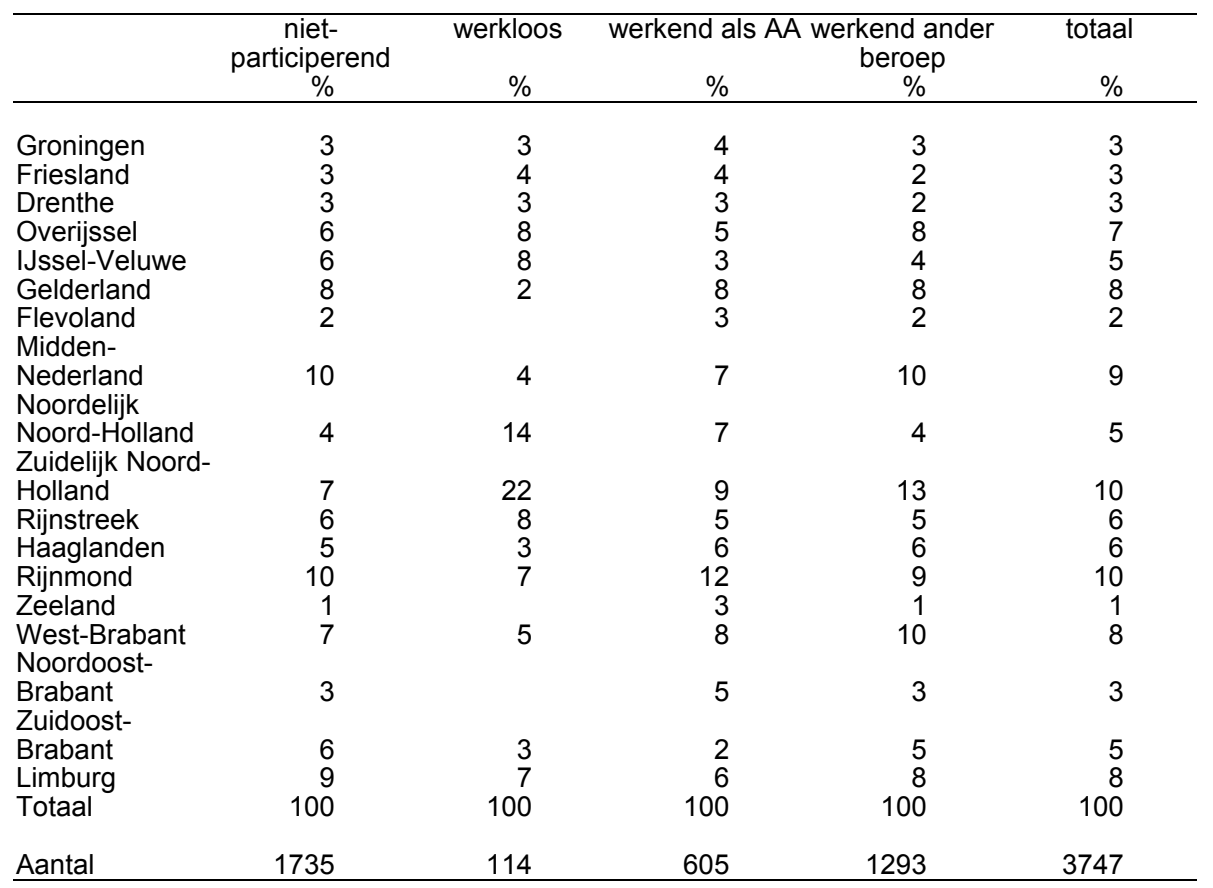

Tabel 6

Leeftijd (jaren)

\begin{tabular}{lccccc}
\hline & $\begin{array}{c}\text { niet- } \\
\text { participerend } \\
\%\end{array}$ & $\begin{array}{c}\text { werkloos } \\
\%\end{array}$ & $\begin{array}{c}\text { werkend } \\
\text { als AA } \\
\%\end{array}$ & $\begin{array}{c}\text { werkend ander } \\
\text { beroep } \\
\%\end{array}$ & $\begin{array}{c}\text { totaal } \\
\%\end{array}$ \\
\hline $20-29$ & 10 & 5 & 17 & 14 & 12 \\
$30-39$ & 48 & 16 & 36 & 39 & 42 \\
$40-49$ & 24 & 27 & 32 & 37 & 30 \\
$50-58$ & 19 & 51 & 15 & 9 & 16 \\
Totaal & 100 & 100 & 100 & 100 & 100 \\
Aantal & 1735 & 114 & 605 & 1293 & 3747 \\
\hline
\end{tabular}


Tabel 7

Diplomajaar van opleiding tot apothekersassistent (AA)

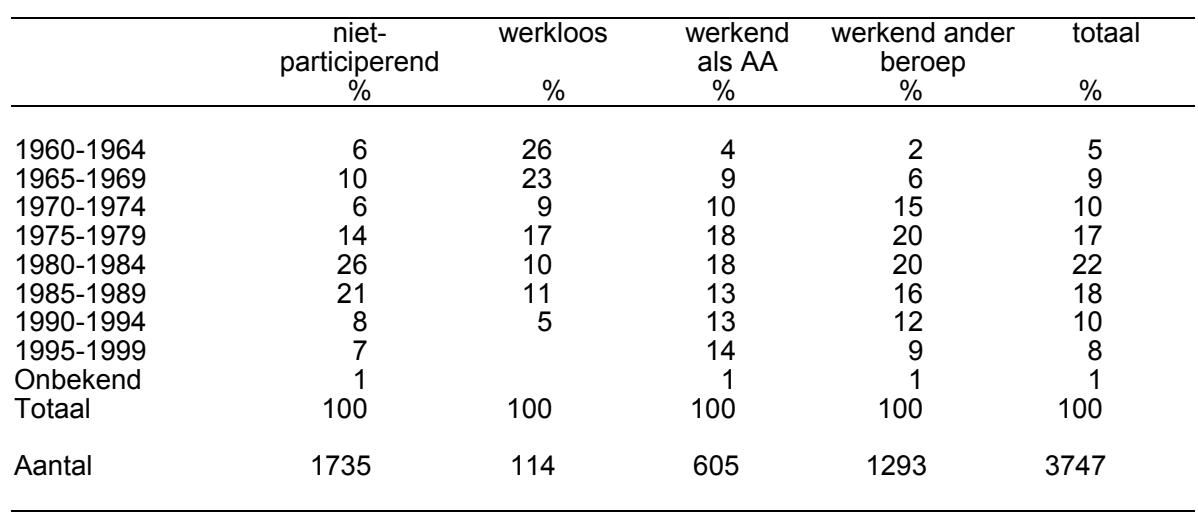

Tabel 8

Vervolgopleiding gevolgd

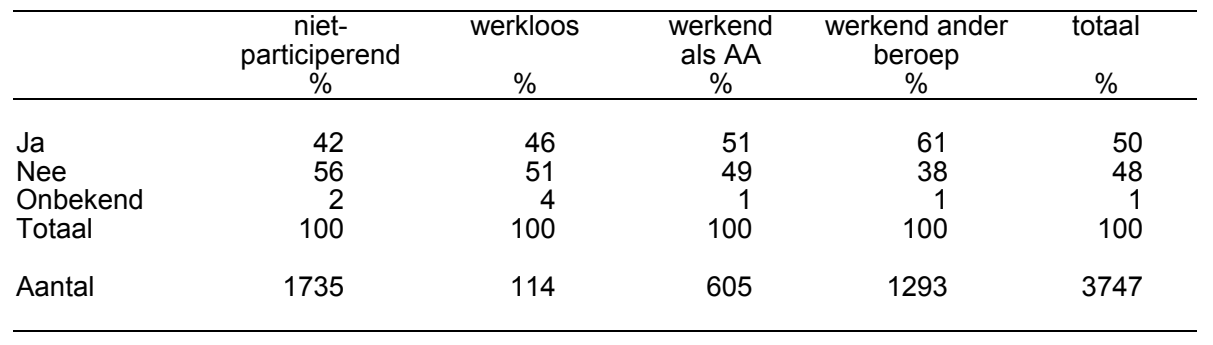

Tabel 9

Diploma behaald voor vervolgopleiding

\begin{tabular}{|c|c|c|c|c|c|}
\hline & $\begin{array}{c}\text { niet- } \\
\text { participerend } \\
\% \\
\end{array}$ & $\begin{array}{r}\text { werkloos } \\
\% \\
\end{array}$ & $\begin{array}{r}\text { werkend } \\
\text { als AA } \\
\% \\
\end{array}$ & $\begin{array}{c}\text { werkend ander } \\
\text { beroep } \\
\% \\
\end{array}$ & totaal \\
\hline $\mathrm{Ja}$ & 82 & 89 & 89 & 90 & 87 \\
\hline Nee & 17 & 12 & 10 & 9 & 12 \\
\hline Onbekend & 2 & & 1 & 1 & 1 \\
\hline Totaal & 100 & 100 & 100 & 100 & 100 \\
\hline Aantal & 736 & 52 & 306 & 790 & 1884 \\
\hline
\end{tabular}

Tabel 10a

Niveau van de laatste met diploma afgesloten vervolgopleiding

\begin{tabular}{lccccr}
\hline & $\begin{array}{c}\text { niet- } \\
\text { participerend } \\
\%\end{array}$ & $\begin{array}{c}\text { werkloos } \\
\%\end{array}$ & $\begin{array}{c}\text { werkend } \\
\text { als AA } \\
\%\end{array}$ & $\begin{array}{c}\text { werkend ander } \\
\text { beroep } \\
\%\end{array}$ & $\begin{array}{c}\text { totaal } \\
\%\end{array}$ \\
\hline MBO & 39 & 53 & 51 & 50 & 46 \\
HBO & 14 & 9 & 12 & 23 & 17 \\
WO & 2 & & 2 & 2 & 2 \\
Onbekend & 45 & 38 & 35 & 25 & 100 \\
Totaal & 100 & 100 & 100 & 709 & 1633 \\
Aantal & 604 & 47 & 273 & & \\
\hline
\end{tabular}


Tabel $10 b$

Richting van de laatste met een diploma afgesloten vervolgopleiding

\begin{tabular}{lccccc}
\hline & $\begin{array}{c}\text { niet- } \\
\text { participend } \\
\%\end{array}$ & $\begin{array}{c}\text { werkloos } \\
\%\end{array}$ & $\begin{array}{c}\text { werkend } \\
\text { als AA } \\
\%\end{array}$ & $\begin{array}{c}\text { werkend ander } \\
\text { beroep } \\
\%\end{array}$ & $\begin{array}{c}\text { totaal } \\
\%\end{array}$ \\
\hline $\begin{array}{l}\text { Farmaceutisch } \\
\text { Gezondheidszorg }\end{array}$ & 36 & 38 & 44 & 17 & 29 \\
$\begin{array}{l}\text { overig } \\
\begin{array}{l}\text { Economisch, } \\
\text { administratief }\end{array}\end{array}$ & 16 & 6 & 22 & 19 & 18 \\
$\begin{array}{l}\text { commercieel } \\
\begin{array}{l}\text { Onbekend } \\
\text { Totaal }\end{array}\end{array}$ & 16 & 19 & 6 & 23 & 18 \\
Aantal & 100 & 37 & 28 & 41 & 35 \\
& 604 & 47 & 273 & 700 & 1633 \\
\hline
\end{tabular}

Tabel 11a

Laatste jaar gewerkt ongeacht beroep

\begin{tabular}{|c|c|c|c|}
\hline & $\begin{array}{c}\text { niet- } \\
\text { participerend } \\
\%\end{array}$ & $\begin{array}{c}\text { werkloos } \\
\%\end{array}$ & $\begin{array}{c}\text { totaa } \\
\% \\
\end{array}$ \\
\hline $\begin{array}{l}1975-1979 \\
1980-1984 \\
1985-1989 \\
1990-1994 \\
1995 \\
1996 \\
1997 \\
1998 \\
1999 \\
2000 \\
2001 \\
\text { Onbekend } \\
\text { Totaal }\end{array}$ & $\begin{array}{r}1 \\
2 \\
5 \\
28 \\
6 \\
8 \\
6 \\
8 \\
11 \\
9 \\
14 \\
1 \\
100\end{array}$ & $\begin{array}{r}4 \\
14 \\
3 \\
3 \\
8 \\
9 \\
21 \\
17 \\
20\end{array}$ & $\begin{array}{r}1 \\
2 \\
5 \\
28 \\
5 \\
8 \\
7 \\
8 \\
12 \\
9 \\
15 \\
1 \\
100\end{array}$ \\
\hline Aantal & 1735 & 114 & 1849 \\
\hline
\end{tabular}

Tabel $11 b$

Laatste jaar gewerkt als apothekersassistent

\begin{tabular}{|c|c|c|c|c|c|}
\hline & $\begin{array}{c}\text { niet- } \\
\text { participerend } \\
\% \\
\end{array}$ & $\begin{array}{c}\text { werkloos } \\
\%\end{array}$ & $\begin{array}{c}\text { werkend } \\
\text { als AA } \\
\%\end{array}$ & $\begin{array}{c}\text { werkend ander } \\
\text { beroep } \\
\%\end{array}$ & $\begin{array}{c}\text { totaal } \\
\% \\
\end{array}$ \\
\hline $1975-1979$ & 2 & 4 & 1 & 1 & 1 \\
\hline $1980-1984$ & 2 & & 2 & 1 & 1 \\
\hline 1985-1989 & 6 & & 4 & 6 & 5 \\
\hline 1990-1994 & 36 & 31 & 28 & 39 & 36 \\
\hline 1995 & 9 & 11 & 6 & 7 & 8 \\
\hline 1996 & 8 & 3 & 8 & 6 & 7 \\
\hline 1997 & 8 & 13 & 9 & 7 & 8 \\
\hline 1998 & 9 & 19 & 10 & 9 & 10 \\
\hline 1999 & 13 & 14 & 20 & 15 & 15 \\
\hline 2000 & 8 & 6 & 13 & 9 & 9 \\
\hline Totaal & 100 & 100 & 100 & 100 & 100 \\
\hline Aantal & 1735 & 114 & 605 & 1293 & 3747 \\
\hline
\end{tabular}


Tabel 12

Reden van stoppen met werk als apothekersassistent in de openbare apotheek

\begin{tabular}{|c|c|c|c|c|c|}
\hline & $\begin{array}{c}\text { niet- } \\
\text { participerend } \\
\% \\
\end{array}$ & $\%$ & $\begin{array}{c}\text { werkend } \\
\text { als AA } \\
\% \\
\%\end{array}$ & $\begin{array}{c}\text { werkend } \\
\text { ander } \\
\text { beroep } \\
\% \\
\end{array}$ & totaal \\
\hline $\begin{array}{l}\text { Zorg voor kinderen, huishoudelijk } \\
\text { werkof andere zorgtaken } \\
\text { Te weinig faciliteiten voor kinder- } \\
\text { of buitenschoolse opvang } \\
\text { Studie } \\
\text { Werk was niet leuk genoeg } \\
\text { Werk bood te weinig } \\
\text { carrièreperspectief } \\
\text { Werk was financieel niet } \\
\text { aantrekkelijk genoeg } \\
\text { Reistijd naar het werk } \\
\text { Te weinig mogelijkheden voor } \\
\text { deeltijdwerk } \\
\text { Te weinig mogelijkheden voor } \\
\text { flexibele werktijden } \\
\text { Onregelmatige diensten } \\
\text { Hoge werkdruk } \\
\text { Onvrijwillig werkloos geworden } \\
\text { Gezondheid } \\
\text { Overig } \\
\text { Onbekend } \\
\text { Totaal }\end{array}$ & $\begin{array}{r}5 \\
3 \\
1 \\
3 \\
3 \\
6 \\
10 \\
4 \\
100\end{array}$ & $\begin{array}{r}2 \\
8 \\
29 \\
10 \\
4 \\
8 \\
100\end{array}$ & $\begin{array}{r}8 \\
1 \\
3 \\
9 \\
4 \\
1 \\
21 \\
10 \\
100\end{array}$ & $\begin{array}{r}7 \\
3 \\
2 \\
4 \\
5 \\
4 \\
16 \\
5 \\
100\end{array}$ & $\begin{array}{r}6 \\
2 \\
1 \\
5 \\
5 \\
5 \\
14 \\
5 \\
100\end{array}$ \\
\hline Aantal & 1735 & 114 & 605 & 1293 & 3747 \\
\hline
\end{tabular}

Tabel 13

Huidige of laatste baan

\begin{tabular}{lccccr}
\hline & $\begin{array}{c}\text { niet- } \\
\text { participerend }\end{array}$ & $\begin{array}{c}\text { werkloos } \\
\%\end{array}$ & $\begin{array}{c}\text { werkend } \\
\text { als AA }\end{array}$ & $\begin{array}{c}\text { werkend } \\
\text { ander } \\
\text { beroep } \\
\%\end{array}$ & totaal \\
\hline $\begin{array}{l}\text { Werk als apothekersassistent } \\
\begin{array}{l}\text { Werk in een ander beroep binnen } \\
\text { de gezondheidszorg }\end{array}\end{array}$ & 76 & 57 & 100 & & 53 \\
$\begin{array}{l}\text { Werk in economisch-administra- } \\
\text { tieve of commerciële functie }\end{array}$ & 5 & 17 & & 21 & 10 \\
$\begin{array}{l}\text { Overig werk } \\
\text { Onbekend }\end{array}$ & 9 & 24 & & 47 & 21 \\
$\begin{array}{l}\text { Totaal } \\
\text { Aantal }\end{array}$ & 100 & 100 & 100 & 100 & 15 \\
& 1735 & 114 & 605 & 1293 & 3747 \\
\hline
\end{tabular}


Tabel 14

Werkervaring als apothekersassistent (jaren)

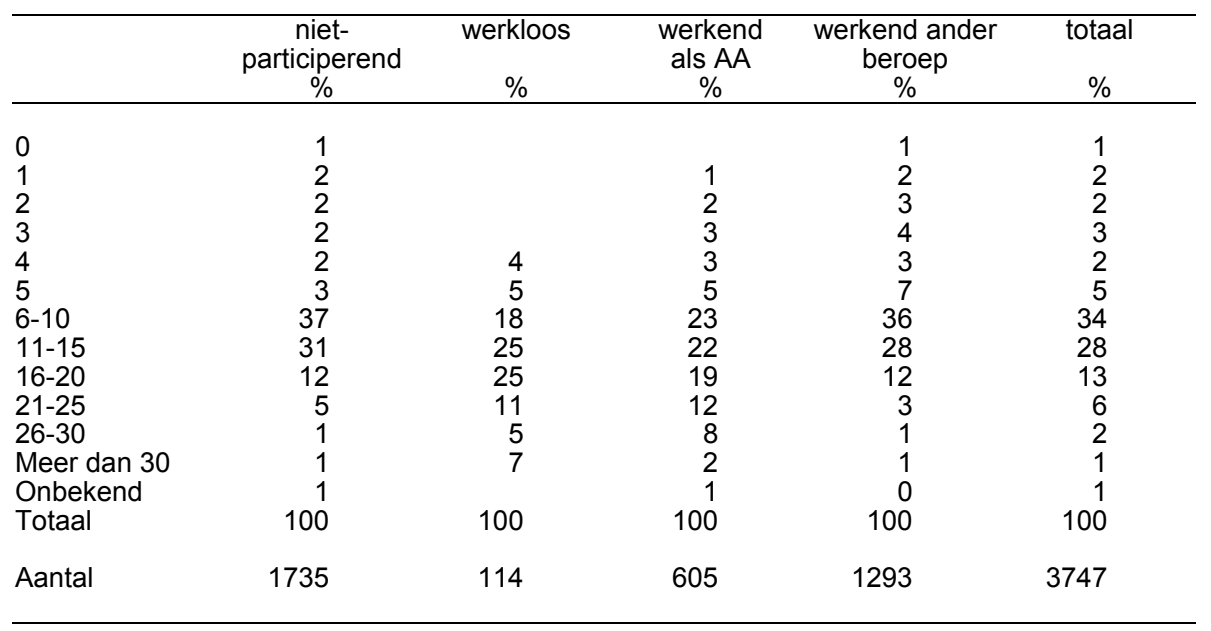

Tabel 15

Werk als apothekersassistent met plezier gedaan

\begin{tabular}{|c|c|c|c|c|c|}
\hline & $\begin{array}{c}\text { niet- } \\
\text { participerend } \\
\% \\
\end{array}$ & $\begin{array}{c}\text { werkloos } \\
\% \\
\end{array}$ & $\begin{array}{c}\text { werkend } \\
\text { als AA } \\
\% \\
\end{array}$ & $\begin{array}{c}\text { werkend ander } \\
\text { beroep } \\
\% \\
\end{array}$ & $\begin{array}{c}\text { totaa } \\
\% \\
\end{array}$ \\
\hline $\begin{array}{l}\text { Ja } \\
\text { Nee } \\
\text { Onbekend } \\
\text { Totaal }\end{array}$ & $\begin{array}{r}94 \\
4 \\
1 \\
100\end{array}$ & $\begin{array}{r}91 \\
6 \\
3 \\
100\end{array}$ & $\begin{array}{r}95 \\
3 \\
3 \\
100\end{array}$ & $\begin{array}{r}92 \\
7 \\
1 \\
100\end{array}$ & $\begin{array}{r}94 \\
5 \\
2 \\
100\end{array}$ \\
\hline Aantal & 1735 & 114 & 605 & 1293 & 3747 \\
\hline
\end{tabular}

Tabel $16 a$

Keuze van opleiding tot apothekersassistent achteraf bezien de juiste

\begin{tabular}{lccccr}
\hline & $\begin{array}{c}\text { niet- } \\
\text { participerend } \\
\%\end{array}$ & $\begin{array}{c}\text { werkloos } \\
\%\end{array}$ & $\begin{array}{c}\text { werkend } \\
\text { als AA } \\
\%\end{array}$ & $\begin{array}{c}\text { werkend ander } \\
\text { beroep } \\
\%\end{array}$ & $\begin{array}{c}\text { totaal } \\
\%\end{array}$ \\
\hline Ja & 53 & 50 & 48 & 43 & 49 \\
Nee & 45 & 50 & 51 & 55 & 49 \\
Onbekend & 2 & 100 & 100 & 100 & 2 \\
Totaal & 100 & 114 & 605 & 1293 & 3747 \\
Aantal & 1735 & & & & \\
\hline
\end{tabular}


Tabel $16 b$

Reden voor negatief beeld van opleiding tot apothekersassistent (meerdere antwoorden mogelijk)

\begin{tabular}{|c|c|c|c|c|c|}
\hline & $\begin{array}{c}\text { niet- } \\
\text { participerend } \\
\% \\
\end{array}$ & werkloos & $\begin{array}{c}\text { werkend } \\
\text { als AA } \\
\% \\
\%\end{array}$ & $\begin{array}{c}\text { werkend } \\
\text { ander } \\
\text { beroep } \\
\% \\
\end{array}$ & totaal \\
\hline Opleiding niet interessant & 5 & 7 & 7 & 5 & 6 \\
\hline $\begin{array}{l}\text { Andere opleidingen sluiten } \\
\text { beter aan }\end{array}$ & 4 & 0 & 3 & 11 & 6 \\
\hline $\begin{array}{l}\text { Niets/weinig aan opleiding } \\
\text { gehad }\end{array}$ & 2 & 0 & 0 & 1 & 1 \\
\hline Werk als AA niet leuk & 13 & 14 & 6 & 19 & 14 \\
\hline $\begin{array}{l}\text { Werk biedt weinig carrièreper- } \\
\text { spectief }\end{array}$ & 52 & 51 & 69 & 54 & 56 \\
\hline $\begin{array}{l}\text { Werk niet financieel aantrek- } \\
\text { kelijk }\end{array}$ & 57 & 72 & 75 & 52 & 59 \\
\hline Onregelmatige diensten & 21 & 33 & 20 & 15 & 19 \\
\hline Hoge werkdruk & 34 & 74 & 33 & 25 & 32 \\
\hline niet aantrekkelijk & 15 & 21 & 18 & 15 & 16 \\
\hline Overige redenen & 21 & 19 & 12 & 19 & 19 \\
\hline Aantal & 781 & 57 & 309 & 711 & 1836 \\
\hline
\end{tabular}

Tabel 17

Persoonlijke situatie (meerdere antwoorden mogelijk)

\begin{tabular}{lccccc}
\hline & $\begin{array}{c}\text { niet- } \\
\text { participerend }\end{array}$ & $\begin{array}{c}\text { werkloos } \\
\%\end{array}$ & $\begin{array}{c}\text { werkend } \\
\text { als AA }\end{array}$ & $\begin{array}{c}\text { werkend } \\
\text { ander } \\
\text { beroep } \\
\%\end{array}$ & totaal \\
\hline $\begin{array}{l}\text { Huishoudelijk werk / verzor- } \\
\text { ging kinderen }\end{array}$ & 79 & 44 & 46 & 42 & $\%$ \\
$\begin{array}{l}\text { Werkend } \\
\text { Werkloos }\end{array}$ & 10 & 5 & 100 & 100 & 56 \\
Studerend & 2 & 100 & & & 4 \\
Arbeidsongeschikt & 13 & & & & 3 \\
Overig & 6 & & & & 8 \\
Aantal & 17 & & & & 3747 \\
\hline
\end{tabular}

Tabel 18

Betaald werk (uren per week)

\begin{tabular}{lccc}
\hline & $\begin{array}{c}\text { werkend } \\
\text { als AA } \\
\%\end{array}$ & werkend ander beroep & totaal \\
\hline tot en met 8 & 7 & 7 & $\%$ \\
9 tot en met 16 & 22 & 21 & 21 \\
17 tot en met 24 & 24 & 25 & 25 \\
25 tot en met 32 & 17 & 15 & 16 \\
33 tot en met 40 & 22 & 26 & 24 \\
Meer dan 40 & 1 & 4 & 3 \\
Onbekend & 7 & 2 & 4 \\
Totaal & 100 & 100 & 100 \\
& & 1293 & 1898 \\
Aantal & 605 & & \\
\hline
\end{tabular}


Tabel 19

Persoonlijke netto inkomen per maand in guldens (euro's)

\begin{tabular}{|c|c|c|c|c|c|}
\hline & $\begin{array}{c}\text { niet- } \\
\text { participerend } \\
\%\end{array}$ & $\begin{array}{c}\text { werkloos } \\
\%\end{array}$ & $\begin{array}{c}\text { werkend } \\
\text { als AA } \\
\%\end{array}$ & $\begin{array}{c}\text { werkend ander } \\
\text { beroep } \\
\%\end{array}$ & $\begin{array}{c}\text { totaa } \\
\%\end{array}$ \\
\hline $0-999(€ 0-453)$ & 55 & 33 & 10 & 11 & 32 \\
\hline $1000-1999(€ 454-907)$ & 6 & 17 & 29 & 22 & 16 \\
\hline $2000-2999(€ 908-1361)$ & 5 & 18 & 30 & 24 & 16 \\
\hline $\begin{array}{l}3000-3999(€ 1361- \\
1815)\end{array}$ & 1 & & 7 & 11 & 6 \\
\hline $\begin{array}{l}4000-4999(€ 1815- \\
2268)\end{array}$ & 0 & & 1 & 3 & 1 \\
\hline $5000-5999(€ 2269-$ & 1 & & 1 & 0 & 1 \\
\hline $\begin{array}{l}2722) \\
6000-6999(€ 2723-\end{array}$ & 0 & & & 0 & 0 \\
\hline $\begin{array}{l}3176) \\
7000-7999(€ 3176-\end{array}$ & 0 & & & & 0 \\
\hline $\begin{array}{l}3630) \\
\text { Onbekend }\end{array}$ & 32 & 33 & 21 & 29 & 29 \\
\hline Totaal & 100 & 100 & 100 & 100 & 100 \\
\hline Aantal & 1735 & 114 & 605 & 1293 & 3747 \\
\hline
\end{tabular}

Tabel 20

Personen met samenwonende partner

\begin{tabular}{lccccc}
\hline & $\begin{array}{c}\text { niet- } \\
\text { participerend } \\
\%\end{array}$ & $\begin{array}{c}\text { werkloos } \\
\%\end{array}$ & $\begin{array}{c}\text { werkend } \\
\text { als AA } \\
\%\end{array}$ & $\begin{array}{c}\text { werkend ander } \\
\text { beroep } \\
\%\end{array}$ & $\begin{array}{c}\text { totaal } \\
\%\end{array}$ \\
\hline $\mathrm{Ja}$ & 91 & 83 & 78 & 84 & 86 \\
Nee & 9 & 17 & 20 & 16 & 14 \\
Onbekend & 0 & 100 & 100 & 100 & 0 \\
Totaal & 100 & 100 & & 100 \\
Aantal & 1735 & 114 & 605 & 1293 & 3747 \\
\hline
\end{tabular}

Tabel 21

Situatie partner (meerdere antwoorden mogelijk)

\begin{tabular}{lccccc}
\hline & $\begin{array}{c}\text { niet- } \\
\text { participerend } \\
\%\end{array}$ & $\begin{array}{c}\text { werkloos } \\
\%\end{array}$ & $\begin{array}{c}\text { werkend } \\
\text { als AA } \\
\%\end{array}$ & $\begin{array}{c}\text { werkend ander } \\
\text { beroep } \\
\%\end{array}$ & $\begin{array}{c}\text { totaal } \\
\%\end{array}$ \\
\hline Werkend, voltijd & 83 & 75 & 78 & 83 & 82 \\
Werkend, < 33 uur & 3 & 2 & 8 & 7 & 5 \\
Huishoudelijk werk & 1 & 2 & 10 & 4 & 4 \\
Werkloos & 0 & 0 & 0 & 0 & 0 \\
VUT/pensioen & 6 & 10 & 1 & 1 & 4 \\
Arbeidsongeschikt & 2 & 0 & 1 & 1 & 1 \\
Overig & 7 & 13 & 8 & 7 & 7 \\
Aantal & 1581 & 96 & 477 & 1085 & 3239 \\
\hline
\end{tabular}


Tabel 22

Totale netto maandinkomen van gediplomeerde apothekersassistent en (eventueel) partner in guldens (euro's)

\begin{tabular}{|c|c|c|c|c|c|}
\hline & $\begin{array}{c}\text { niet- } \\
\text { participerend } \\
\% \\
\end{array}$ & $\begin{array}{c}\text { werkloos } \\
\%\end{array}$ & $\begin{array}{l}\text { werkend } \\
\text { als AA } \\
\%\end{array}$ & $\begin{array}{c}\text { werkend ander } \\
\text { beroep } \\
\%\end{array}$ & $\begin{array}{c}\text { totaal } \\
\%\end{array}$ \\
\hline $\begin{array}{l}0-999(€ 0-453) \\
1000-1999(€ 454-907)\end{array}$ & 2 & 3 & 4 & 2 & 3 \\
\hline $\begin{array}{l}1000-1999(€ 454-907) \\
2000-2999(€ 908-1361)\end{array}$ & & 5 & 1 & & \\
\hline $\begin{array}{l}2000-2999(€ 908-1361) \\
3000-3999(€ 1361-\end{array}$ & 4 & 2 & 7 & 3 & 4 \\
\hline $\begin{array}{l}3000-3999(€ 1361- \\
1815)\end{array}$ & 14 & 9 & 12 & 8 & 11 \\
\hline $\begin{array}{l}\text { 4000-4999 (€ 1815- } \\
2268)\end{array}$ & 13 & 12 & 13 & 12 & 13 \\
\hline $\begin{array}{l}5000-5999 \text { (€ 2269- } \\
2722)\end{array}$ & 8 & 2 & 11 & 11 & 9 \\
\hline $\begin{array}{l}\text { 6000-6999 (€ 2723- } \\
3176)\end{array}$ & 5 & 3 & 4 & 10 & 6 \\
\hline $\begin{array}{l}7000-7999(€ 3176- \\
3630)\end{array}$ & 3 & 3 & 6 & 7 & 5 \\
\hline$>8000(€ 3630)$ & 3 & 4 & 3 & 4 & 4 \\
\hline onbekend & 48 & 56 & 39 & 43 & 45 \\
\hline Totaal & 100 & 100 & 100 & 100 & 100 \\
\hline Aantal & 1581 & 96 & 477 & 1085 & 3239 \\
\hline
\end{tabular}

Tabel 23

Bereidheid tot werken als $A A$ in $O A$

\begin{tabular}{|c|c|c|c|c|c|}
\hline & $\begin{array}{c}\text { niet- } \\
\text { participerend } \\
\% \\
\end{array}$ & werkloos & $\begin{array}{c}\text { werkend } \\
\text { als AA } \\
\% \\
\%\end{array}$ & $\begin{array}{c}\text { werkend } \\
\text { ander } \\
\text { beroep } \\
\%\end{array}$ & totaal \\
\hline 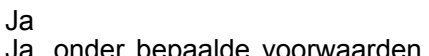 & 8 & 13 & 7 & 7 & 8 \\
\hline of op termijn & 48 & 50 & 29 & 35 & 40 \\
\hline Nee & 44 & 37 & 61 & 58 & 51 \\
\hline Onbekend & 1 & & 3 & 1 & 1 \\
\hline Totaal & 100 & 100 & 100 & 100 & 100 \\
\hline Aantal & 1735 & 114 & 605 & 1293 & 3747 \\
\hline
\end{tabular}

Tabel 24

Gewenste aantal uren per werkweek

\begin{tabular}{lccccc}
\hline & $\begin{array}{c}\text { niet- } \\
\text { participend } \\
\%\end{array}$ & $\begin{array}{c}\text { werkloos } \\
\%\end{array}$ & $\begin{array}{c}\text { werkend } \\
\text { als AA } \\
\%\end{array}$ & $\begin{array}{c}\text { werkend } \\
\text { ander beroep } \\
\%\end{array}$ & $\begin{array}{c}\text { totaal } \\
\%\end{array}$ \\
\hline 1 tot en met 8 & 6 & 11 & 5 & 2 & 5 \\
9 tot en met 16 & 65 & 59 & 41 & 35 & 53 \\
17 tot en met 24 & 22 & 21 & 27 & 36 & 27 \\
25 tot en met 32 & 2 & 1 & 11 & 13 & 6 \\
33 tot en met 40 & 1 & 4 & 14 & 12 & 3 \\
Onbekend & 5 & 3 & 2 & 100 & 100 \\
Totaal & 100 & 100 & 100 & 538 & 1797 \\
Aantal & 969 & 72 & 218 & & \\
\hline
\end{tabular}


Tabel 25

Gewenste netto maandloon in guldens (euro's)

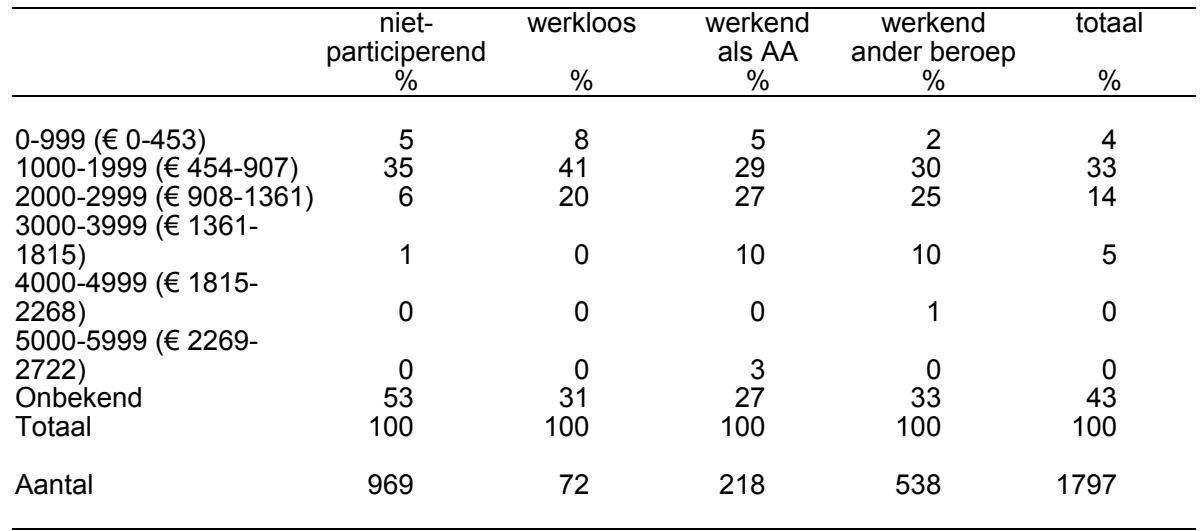

Tabel 26

Meest aantrekkelijke aspecten van het werk als AA in OA (meerdere antwoorden mogelijk)

\begin{tabular}{lccccc}
\hline & $\begin{array}{c}\text { niet- } \\
\text { participerend } \\
\%\end{array}$ & $\begin{array}{c}\text { werkloos } \\
\%\end{array}$ & $\begin{array}{c}\text { werkend als } \\
\text { AA } \\
\%\end{array}$ & $\begin{array}{c}\text { werkend } \\
\text { ander beroep } \\
\%\end{array}$ & $\begin{array}{c}\text { totaal } \\
\%\end{array}$ \\
\hline $\begin{array}{l}\text { Kennis van } \\
\text { geneesmiddelen }\end{array}$ & 78 & 82 & 81 & 80 & 79 \\
$\begin{array}{l}\text { Bereiding van } \\
\text { geneesmiddelen }\end{array}$ & 60 & 60 & 57 & 62 & 60 \\
$\begin{array}{l}\text { Verantwoordelijkheid } \\
\text { Zelfstandigheid }\end{array}$ & 26 & 26 & 34 & 37 & 30 \\
$\begin{array}{l}\text { Dienstverlening } \\
\text { Werksfeer }\end{array}$ & 30 & 31 & 44 & 34 & 33 \\
$\begin{array}{l}\text { Financiële } \\
\text { aantrekkelijkheid }\end{array}$ & 76 & 74 & 64 & 77 & 75 \\
Aantrekkelijkheid overige & 65 & 74 & 62 & 57 & 63 \\
arbeidsvoorwaarden & 8 & 14 & 10 & 7 & 8 \\
Overige & 3 & & & & 5 \\
Geen & 2 & 7 & 10 & 6 & 2 \\
Aantal & 0 & 7 & 1 & 1 & 0 \\
\hline
\end{tabular}

Tabel 27

Binnen 4 weken kunnen beginnen met werken

\begin{tabular}{lccccc}
\hline & $\begin{array}{c}\text { niet- } \\
\text { participerend } \\
\%\end{array}$ & $\begin{array}{c}\text { werkloos } \\
\%\end{array}$ & $\begin{array}{c}\text { werkend } \\
\text { als AA } \\
\%\end{array}$ & $\begin{array}{c}\text { werkend ander } \\
\text { beroep } \\
\%\end{array}$ & $\begin{array}{c}\text { totaal } \\
\%\end{array}$ \\
\hline $\mathrm{Ja}$ & 28 & 65 & 16 & 18 & 25 \\
$\mathrm{Nee}$ & 58 & 22 & 22 & 39 & 47 \\
Onbekend & 15 & 13 & 63 & 43 & 28 \\
Totaal & 100 & 100 & 100 & 100 & 100 \\
Aantal & 969 & 72 & 218 & 538 & 1797 \\
\hline
\end{tabular}


Tabel 28

Laatste drie maanden (ander) werk gezocht

\begin{tabular}{lcccrr}
\hline & $\begin{array}{c}\text { niet- } \\
\text { participerend } \\
\%\end{array}$ & $\begin{array}{c}\text { werkloos } \\
\%\end{array}$ & $\begin{array}{c}\text { werkend } \\
\text { als AA } \\
\%\end{array}$ & $\begin{array}{c}\text { werkend ander } \\
\text { beroep } \\
\%\end{array}$ & $\begin{array}{c}\text { totaal } \\
\%\end{array}$ \\
\hline Ja & 13 & 49 & 22 & 18 & 17 \\
$\begin{array}{l}\text { Nee } \\
\text { Onbekend }\end{array}$ & 87 & 51 & 78 & 81 & 83 \\
Totaal & 100 & 100 & 100 & 100 & 0 \\
Aantal & 969 & 72 & 218 & 538 & 1797 \\
\hline
\end{tabular}

Tabel 29

Tijd ingeschreven bij arbeidsbureau (maanden)

\begin{tabular}{lccc}
\hline & $\begin{array}{c}\text { niet- } \\
\text { participerend } \\
\%\end{array}$ & werkloos & totaal \\
\hline tot en met 6 & 13 & $\%$ & 16 \\
7 tot en met 12 & 34 & 20 & 25 \\
13 tot en met 24 & 11 & 12 & 24 \\
25 tot en met 60 & 34 & 44 & 24 \\
61 tot en met 70 & 8 & 8 & 11 \\
Totaal & 100 & 100 & 100 \\
Aantal & 38 & 25 & 63 \\
\end{tabular}

Tabel 30

Maximaal acceptabele reistijd (minuten)

\begin{tabular}{lcccrr}
\hline & $\begin{array}{c}\text { niet- } \\
\text { participerend } \\
\%\end{array}$ & werkloos & $\begin{array}{c}\text { werkend als } \\
\text { AA } \\
\%\end{array}$ & $\begin{array}{c}\text { werkend ander } \\
\text { beroep } \\
\%\end{array}$ & $\begin{array}{c}\text { totaal } \\
\%\end{array}$ \\
\hline 1 tot en met 10 & 7 & 5 & 1 & 4 & 5 \\
11 tot en met 20 & 53 & 28 & 36 & 39 & 45 \\
21 tot en met 30 & 37 & 51 & 44 & 47 & 2 \\
31 tot en met 40 & 1 & 2 & 5 & 6 & 4 \\
41 tot en met 50 & 3 & 12 & 6 & 3 & 100 \\
51 tot en met 60 & 1 & 3 & 100 & 100 & 1797 \\
Totaal & 100 & 100 & 218 & 538 & \\
Aantal & 969 & 72 & & &
\end{tabular}

Tabel 31

Sneller functie accepteren indien mogelijkheid van flexibele werktijden

\begin{tabular}{|c|c|c|c|c|c|}
\hline & $\begin{array}{c}\text { niet- } \\
\text { participerend } \\
\% \\
\end{array}$ & $\begin{array}{c}\text { werkloos } \\
\% \\
\end{array}$ & $\begin{array}{c}\text { werkend } \\
\text { als AA } \\
\% \\
\end{array}$ & $\begin{array}{c}\text { werkend ander } \\
\text { beroep } \\
\% \\
\end{array}$ & $\begin{array}{c}\text { totaa } \\
\% \\
\end{array}$ \\
\hline $\begin{array}{l}\text { Ja } \\
\text { Nee } \\
\text { Onbekend } \\
\text { Totaal }\end{array}$ & $\begin{array}{r}91 \\
7 \\
2 \\
100\end{array}$ & $\begin{array}{r}88 \\
8 \\
4 \\
100\end{array}$ & $\begin{array}{r}76 \\
24 \\
100\end{array}$ & $\begin{array}{r}83 \\
15 \\
2 \\
100\end{array}$ & $\begin{array}{r}87 \\
12 \\
2 \\
100\end{array}$ \\
\hline Aantal & 969 & 72 & 218 & 538 & 1797 \\
\hline
\end{tabular}


Tabel 32

Noodzaak opfriscursus bij tewerkstelliging als apothekersassistent in de openbare apotheek

\begin{tabular}{lccccc}
\hline & $\begin{array}{c}\text { niet- } \\
\text { participerend } \\
\%\end{array}$ & $\begin{array}{c}\text { werkloos } \\
\%\end{array}$ & $\begin{array}{r}\text { werkend als AA werkend ander } \\
\text { beroep } \\
\%\end{array}$ & $\begin{array}{c}\text { totaal } \\
\%\end{array}$ \\
\hline Ja & 65 & 68 & 32 & 66 & 61 \\
Nee & 31 & 28 & 35 & 27 & 30 \\
Niet van & 4 & 4 & 32 & 6 & 8 \\
toepassing & 1 & & 1 & 1 & 1 \\
$\begin{array}{l}\text { Onbekend } \\
\text { Totaal }\end{array}$ & 100 & 100 & 100 & 100 & 100 \\
Aantal & 969 & 72 & 218 & 538 & 1797 \\
\hline
\end{tabular}

Tabel 33

Terrein opfriscursus (meerdere antwoorden mogelijk)

\begin{tabular}{|c|c|c|c|c|c|}
\hline & $\begin{array}{c}\text { niet- } \\
\text { participerend } \\
\% \\
\end{array}$ & werkloos & $\begin{array}{c}\text { werkend als } \\
\text { AA } \\
\%\end{array}$ & $\begin{array}{l}\text { werkend } \\
\text { ander } \\
\text { beroep } \\
\%\end{array}$ & totaal \\
\hline $\begin{array}{l}\text { Geneesmiddelenkennis } \\
\text { Communicatieve }\end{array}$ & 80 & 82 & 80 & 80 & 81 \\
\hline $\begin{array}{l}\text { vaardigheden } \\
\text { Informatieverstrekking }\end{array}$ & 8 & 6 & 17 & 10 & 9 \\
\hline $\begin{array}{l}\text { geneesmiddelen } \\
\text { Informatica } \\
\text { Recepteren en bereiden }\end{array}$ & $\begin{array}{l}54 \\
53\end{array}$ & $\begin{array}{l}65 \\
59\end{array}$ & $\begin{array}{l}73 \\
30\end{array}$ & $\begin{array}{l}54 \\
38\end{array}$ & $\begin{array}{l}56 \\
48\end{array}$ \\
\hline $\begin{array}{l}\text { geneesmiddelen } \\
\text { Kennis van ziektebeelden } \\
\text { Stage } \\
\text { NVT/niet nodig }\end{array}$ & $\begin{array}{r}31 \\
22 \\
30 \\
0\end{array}$ & $\begin{array}{r}22 \\
35 \\
24 \\
0\end{array}$ & $\begin{array}{r}34 \\
40 \\
10 \\
3\end{array}$ & $\begin{array}{r}41 \\
26 \\
21 \\
1\end{array}$ & $\begin{array}{r}34 \\
25 \\
26 \\
0\end{array}$ \\
\hline Aantal & 630 & 49 & 70 & 355 & 1096 \\
\hline
\end{tabular}


Tabel 34

Redenen om niet als apothekersassistent in de openbare apotheek te werken (meerdere antwoorden mogelijk)

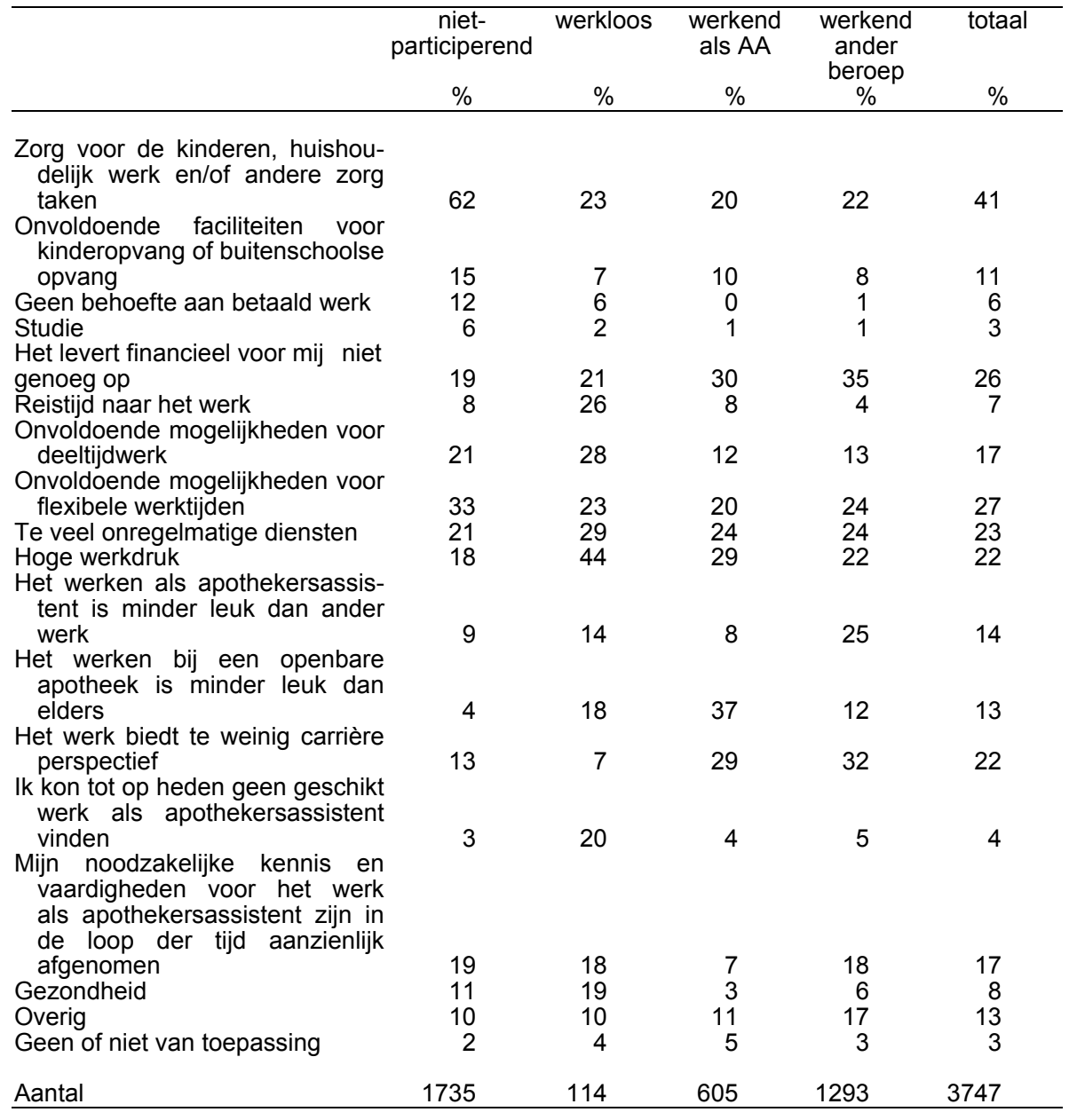

Tabel 35

Aantal thuiswonende kinderen

\begin{tabular}{|c|c|c|c|c|c|}
\hline & $\begin{array}{c}\text { niet- } \\
\text { participerend } \\
\%\end{array}$ & $\begin{array}{c}\text { werkloos } \\
\qquad \%\end{array}$ & $\begin{array}{c}\text { werkend } \\
\text { als AA } \\
\%\end{array}$ & $\begin{array}{c}\text { werkend ander } \\
\text { beroep } \\
\%\end{array}$ & $\begin{array}{c}\text { totaal } \\
\% \\
\end{array}$ \\
\hline 0 & 23 & 50 & 41 & 41 & 33 \\
\hline 1 & 15 & 12 & 19 & 15 & 16 \\
\hline 2 & 41 & 29 & 30 & 35 & 37 \\
\hline 3 & 17 & 3 & 9 & 9 & 12 \\
\hline 4 & 4 & 3 & 2 & 1 & 2 \\
\hline Onbekend & 0 & 3 & & 1 & 0 \\
\hline Totaal & 100 & 100 & 100 & 100 & 100 \\
\hline Aantal & 1735 & 114 & 605 & 1293 & 3747 \\
\hline
\end{tabular}


Tabel 36

Leeftijd jongste kind (jaren)

\begin{tabular}{|c|c|c|c|c|c|}
\hline & $\begin{array}{c}\text { niet- } \\
\text { participerend } \\
\% \\
\end{array}$ & $\begin{array}{c}\text { werkloos } \\
\% \\
\end{array}$ & $\begin{array}{l}\text { werkend } \\
\text { als AA } \\
\%\end{array}$ & $\begin{array}{c}\text { werkend ander } \\
\text { beroep } \\
\%\end{array}$ & $\begin{array}{c}\text { totaal } \\
\%\end{array}$ \\
\hline $\begin{array}{l}0 \\
1 \\
2 \\
3 \\
4 \\
5 \\
6-10 \\
11-15 \\
16-20 \\
21 \text { of ouder } \\
\text { Totaal }\end{array}$ & $\begin{array}{r}8 \\
14 \\
11 \\
13 \\
9 \\
8 \\
23 \\
5 \\
7 \\
2 \\
100\end{array}$ & $\begin{array}{r}9 \\
6 \\
19 \\
\\
4 \\
\\
35 \\
22 \\
6 \\
100\end{array}$ & $\begin{array}{r}6 \\
9 \\
6 \\
4 \\
7 \\
11 \\
25 \\
19 \\
9 \\
4 \\
100\end{array}$ & $\begin{array}{r}3 \\
7 \\
9 \\
7 \\
8 \\
7 \\
30 \\
12 \\
14 \\
4 \\
100\end{array}$ & $\begin{array}{r}6 \\
11 \\
10 \\
9 \\
8 \\
8 \\
26 \\
9 \\
10 \\
3 \\
100\end{array}$ \\
\hline Aantal & 1332 & 54 & 360 & 757 & 2503 \\
\hline
\end{tabular}

Tabel 37

Beschikbaarheid van kinderopvang en werk accepteren

\begin{tabular}{lccccr}
\hline & $\begin{array}{c}\text { niet- } \\
\text { participerend } \\
\%\end{array}$ & $\begin{array}{c}\text { werkloos } \\
\%\end{array}$ & $\begin{array}{c}\text { werkend } \\
\text { als AA } \\
\%\end{array}$ & $\begin{array}{c}\text { werkend ander } \\
\text { beroep } \\
\%\end{array}$ & $\begin{array}{c}\text { totaal } \\
\%\end{array}$ \\
\hline $\begin{array}{l}\text { Van belang } \\
\text { Niet van belang }\end{array}$ & 34 & 44 & 30 & 26 & 31 \\
$\begin{array}{l}\text { Onbekend } \\
\text { Totaal }\end{array}$ & 65 & 56 & 70 & 72 & 68 \\
Aantal & 100 & 100 & 100 & 100 & 1 \\
& 1332 & 54 & 360 & 757 & 2503 \\
\hline
\end{tabular}

Tabel 38

Kosten van kinderopvang en werk accepteren

\begin{tabular}{lccccr}
\hline & $\begin{array}{c}\text { niet- } \\
\text { participerend } \\
\%\end{array}$ & $\begin{array}{c}\text { werkloos } \\
\%\end{array}$ & $\begin{array}{c}\text { werkend } \\
\text { als AA } \\
\%\end{array}$ & $\begin{array}{c}\text { werkend ander } \\
\text { beroep } \\
\%\end{array}$ & $\begin{array}{c}\text { totaal } \\
\%\end{array}$ \\
\hline Van belang & 36 & 35 & 34 & 32 & 35 \\
Niet van belang & 62 & 61 & 64 & 68 & 64 \\
Onbekend & 2 & 4 & 3 & 2 & 2 \\
Totaal & 100 & 100 & 100 & 100 & 100 \\
Aantal & 1332 & 54 & 360 & 757 & 2503 \\
\hline
\end{tabular}

